Portland State University

PDXScholar

1974

\title{
Attitudinal Survey of Children's Services Division Workers Regarding the Louise Home
}

John Adsit

Portland State University

Wendy Bays Heinz

Portland State University

George Nagel

Portland State University

Follow this and additional works at: https://pdxscholar.library.pdx.edu/open_access_etds

Part of the Social Work Commons

Let us know how access to this document benefits you.

\section{Recommended Citation}

Adsit, John; Heinz, Wendy Bays; and Nagel, George, "Attitudinal Survey of Children's Services Division Workers Regarding the Louise Home" (1974). Dissertations and Theses. Paper 1712.

https://doi.org/10.15760/etd.1711

This Thesis is brought to you for free and open access. It has been accepted for inclusion in Dissertations and Theses by an authorized administrator of PDXScholar. Please contact us if we can make this document more accessible: pdxscholar@pdx.edu. 


\section{ATTITUDINAI SURVEY OF CHILDREN'S \\ SERVICES DIVISION WORKERS REGARDING}

THE LOUISE HOME

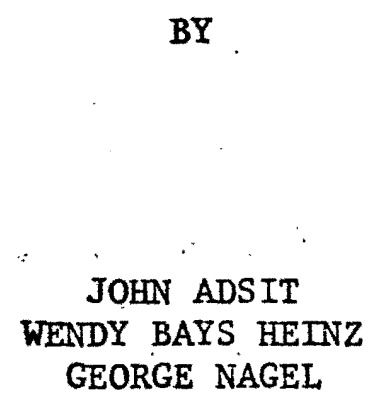

A practicum subnitted in partial fulfillment of the requirements for the degree of

MASTER OF SOCIAL

WORK

Portland State University

1974 
APPROVED:

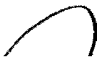

Robett L. Roy

School of Social Work

May 31, 1974 


\section{ACKNOWLEDGEMENTS}

In doing this study we have appreciated the assistance and continuing support of our research advisor, Robert Roy. We are also grateful to the Louise Home administrative staff for their financial assistance; and to each Children's Services Division's district director and their staff who helped us in gathering our data. Finally, a special word of thanks to our typist, Dorothy Bays, for her untiring efforts. 
TABLE OF CONTENTS

PAGE

ACKNOWLEDGMENTS . . . . . . . . . . . . . . . . .

LIST OF TABLES .................... . . .

CHAPTER

I INTRODUCTION ................. 1

II METHODOLOGY ................. 6

III DATA ANALYSIS . . . . . . . . . . . 14

Statistical Plan........... 15

Results.............. 20

Total Sample............. 20

County Samples. . . . . . . . . . 26

Baker. . . . . ...... 26

Clackamas. .......... 29

Columbia ........... 32

Coos............. . 34

Crook. ............. 36

Curry. ............. 38

Deschutes........... 41

Douglas. ........... 43

Harney/Malheur ......... 45

Jefferson. ........... 47

Josephine/Jackson. ....... 49

Klamath/Lake .......... 51

Lane ............ 53

Lincoln. . . . . . . . . . 79

Linn (Unit I)........ 75

Linn (Unit II) . . . . . . . . 77

Multnomah (East) ......... 58

Multnomah (Southeast)....... 61

Multnomah (West) ......... 63

Polk/Yamhill ........... 65

Umatilla . . . . . . . . 67

Union. . . . . . . . . 69

Wallowa. . . . . . . . 72

Washington ........... 72

Marion ............. 56 
CHAPTER

PAGE

IV

SUMMARY. . . . . . . . . . . . . . . .

82

Evaluations .............. 83

Conclusions . . . . . . . . . . 85

Recommendations . . . . . . . . . 88

APPENDICES. . . . . . . . . . . . . . . . 90 
LIST OF TABLES

TABLE

PAGE

I Total Sample Results . . . . . . . . . 21

II Total Sample Correlation Coefficients. . . . . . 23

III No's Sample Results. . . . . . . . . . . 25

IV Baker County Results . . . . . . . . . . 27

v Clackamas County Results . . . . . . . . 30

VI Columbia County Results. . . . . . . . . . 33

VII Coos County Results. . . . . . . . . . 35

VIII Crook County Results . . . . . . . . . . 37

IX Curry County Results . . . . . . . . . . 39

X Deschutes County Results . . . . . . . . 42

XI Douglas County Results . . . . . . . . . . . 44

XII Harney/Malheur Results . . . . . . . . . . 46

XIII Jefferson County Results . . . . . . . . . 48

XIV Josephine/Jackson County Results . . . . . . . 50

XV Klamath/Lake County Results. . . . . . . . . 52

XVI Lane County Results. . . . . . . . . . . 54

XVII Marion County Results. . . . . . . . . 57

XVIII Multnomah County (East) Results. . . . . . . 59

XIX Multnomah County (Southeast) Results . . . . . . 62

XX Multnomah County (West) Results. . . . . . . . 64

XXI Polk/Yamhill County Results. . . . . . . . . 66

XXII Umatilla County Results. . . . . . . . . 68

XXIII Union County Results. . . . . . . . . . 70

XXIV Wallowa County Results . . . . . . . . . 73 


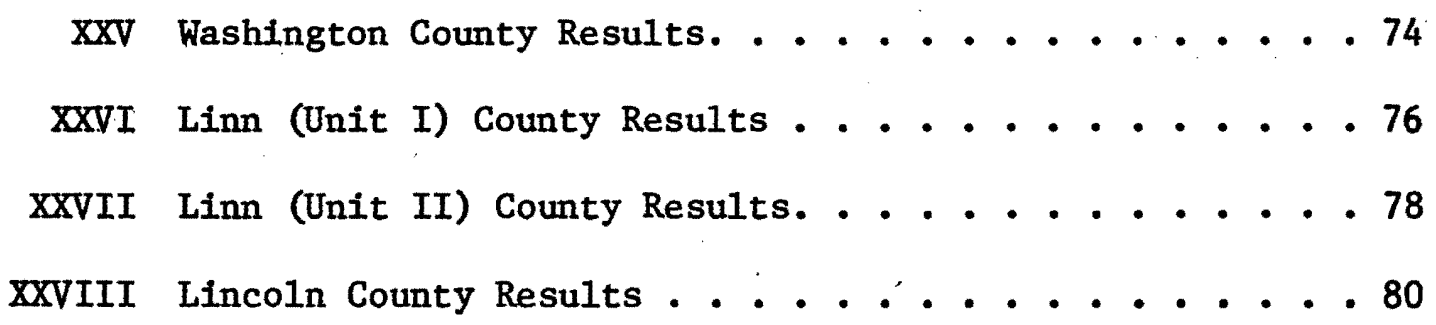


CHAPTER I

INTRODUCTION TO THE SURVEY

OF CHIIDREN'S SERVICES

WORKERS 
This study was initiated by the desire to do a piece of research which would not only be a useful experience for us as social work graduate students, but also would be meeting the needs of an agency In the local community. In exploring the opportunities available to us, we found that the three of us were all employed by the Louise Home for Girls in Portland. In addition we each had a concern for the quality of treatment being provided by the Home. Therefore, we approached the administration of the Louise Home to see if they would be interested in our doing a research project involving the agency.

In discussion with administrative personne1, we found them to be primarily concerned with quality of treatment as it relates to the effect it is having upon the community it serves. It was decided that an explorative study of referral sources of the Louise Home, with regard to their attitudes towards various areas of the treatment program, would be useful. The study would yield valuable information in the following three areas: 1) attitudes of Children's Services Division workers towards the Louise Home, 2) the extent of caseworkers' knowledge about the program, 3) and information that Louise Home could use in evaluating their program.

We hoped that through this study we would be able to attain two primary goals: First, that communication between the Louise Home and its primary sources of referral would be facilitated through the administration of our questionnaire. Our second goal was to provide Louise Home with feedback from their referral sources about the treatment program. This feedback might also reveal how attitudes towards the program and utilization of the facility were related. 
In the early parts of planning the study it became evident that one of the first tasks was to determine who would be the individuals surveyed. We learned that the Louise Home has not always been serving the community in its present capacity. It was first a home for unwed mothers and has gone through a gradual evolution to its present function as a residential treatment center for delinquent and emotionally disturbed boys and girls. The boys' program was added in May 1973. Since it is a separate program and was only recently added to the services the Louise Home offers, we did not include it in our study. As the Louise Home has gone through this developmental process, it has also gone through a change with respect to the primary purchaser of its services. It has become increasingly dependent on state funds and contributions from the United Good Neighbors for its financial support. Children's Services Division (C.S.D.), a state agency for child welfare, has.become the primary source of referral of girls to the Louise Home program. In utilizing the Louise Home services, C.S.D. purchases care for each girl on a daily basis at a fixed rate. Therefore, the attitudes of C.S.D. workers who can refer girls to the Louise Home are important from the standpoints of program evaluation and financial security. Their attitudes may effect the number of girls they refer to the Louise Home. We thus decided that our study should focus upon those C.S.D. workers who can refer girls to the Louise Home. Hence we approached the Louise Home administration with our plans to survey C.S.D. caseworkers' attitudes about the Louise Home. They expressed great interest and proceeded to supply both secretarial and financial assistance.

During our initial work we made some assumptions about the outcome of our study. From the admissions tally sheet provided by the 
agency, we noticed that some counties had very few referrals in relation to the size of the county population. We assumed that these counties might have rather strong opinions about the Louise Home program. A second assumption was that the distance of the county agency from the Louise Home might have an effect upon both knowledge of the program and utilization of its services. The Louise Home administration felt that county agencies nearest to the Louise Home would know less about the Louise Home's program and thus register more neutral responses on the questionnaire.

In addition, we thought that perhaps individuals who had been with the referral agency longer would have stronger opinions than those just having arrived within the past year; that the longer one had been with the agency in a referral position the more knowledgeable and opinionated that person would be. We therefore speculated that those counties having less turnover of personnel would respond more strongly to the questionnaire.

One major question which we wanted the survey to answer was whether or not C.S.D. workers felt there was a need for a facility such as the Louise Home. Thus we posed a question about the treatment facilities for adolescent girls within each county. We were interested in finding out also if there was a general trend away from the use of residential treatment centers.

In eliciting attitudinal responses from C.S.D. caseworkers about the Louise Home program, we were unsure what program areas they knew of and were concerned about. In order to determine the extent of their knowledge and to cover the entire program at the Loulse Home, we decided to ask questions on each general part of the program. We 
thought a strong opinion about a specific aspect of a part of the program might be missed in a short specific questionnaire. Thus, by asking general questions, we could first locate basic treatment components which were functioning, in their opinion, either very well or unsatisfactorily. We decided that further exploration concerning specific positive or negative feelings could be undertaken at a later date by Louise Home staff. We regard this research as basically a beginning. The results of this work may show if further study is necessary, and what areas require more in depth examination. 
CHAPTER II

METHODOLOGY

OF

THE ATTITUDINAL SURVEY 
In this chapter the methodology of our research will be discussed. The first step in our methodology was to develop a questionnaire. We estimated the Children's Services Division population we wanted to survey to be between two hundred and three hundred individuals. We felt the caseworker to be the key individual upon which to focus our survey because in all counties referrals were inftiated by caseworkers. Since this was a rather large sample for us to reach, we decided the least time-consuming and most economical method to survey the attitudes of these individuals would be with a questionnaire which could be self-administered.

The questionnaire which we developed contained twenty-eight statements covering nearly as many aspects of the Louise Home program. The statements were simple and general, as well as positive and negative. Underneath each statement was the following five division response scale: strongly agree, agree, neutral, disagree, strongly disagree. The neutral response was included since it was very probable that at least some caseworkers would not be familiar with every aspect of the Louise Home program represented in the questionnaire. A copy of the questionnaire can be found in Appendix I.

The following list shows each topic and the questions included in the questionnaire which correspond to each topic:

\section{Topic}

Administration

Clerical staff

Intake procedure

Casework

Child care workers

\section{Corresponding Question}

Question 1., Question 4

Question 2.

Question 3.

Question 5.

Question 6. 
Topic

Physical facilities

Treatment philosophy

Recreation program

Freedom of girls

Girls' visitors to Louise Home

Home visits of girls

Residential program

Referrals

Peer control

Runaways

Nutrition

Pre-placement visits

Release procedures

After-care

Medical program

School program

Religious program

Distance of Louise Home

Resources in community
Corresponding Question

Question 7.

Question 8.

Question 9., Question 14.

Question 10.

Question 11.

Question 12.

Question 13.

Question 15., Question 28.

Question 16.

Question 17.

Question 18.

Question 19.

Question 20.

Question 21.

Question 22.

Question 23.

Question 24.

Question 25.

Question 26., Question 27.

The body of the questionnaire was prefaced by a face sheet of seven questions. The first question was developed to find out how many of the Children's Services Division workers filling out the questionnaires were : actually involved in the referral of adolescent girls in the year 1973. The purpose of question two was to determine the population of adolescent females that need residential treatment. Question three was constructed to find out how many of that available population were referred to 
treatment centers. The responses to question four indicate what part of that population was referred to the Louise Home. Question 5's answer reveals how many of those referred to the Louise Home were accepted by Louise Home. The purpose of question six was to find out to which other resources for adolescent girls besides the Louise Home, C.S.D. workers are making referrals. Question seven asks the length of time the C.S.D. worker has been involved in the referral of girls to residential treatment centers. This question was included because we wanted to know if length of time as a C.S.D. worker affected the way an individual responded to questions one through twenty-eight.

The second step of our methodology was to pre-test our questionnaire. Thus we administered the questionnaire to five Clackamas County Juvenile Court workers. What we learned from the pre-test was that a section for comments needed to be added to the questionnaire.' Consequently we left ha1f a page at the end of the questionnaire for comments.

The next step in our survey was to determine which county Children's Services Divisions we would contact and whom in that county would receive questionnaires. By looking at Loulse Home admission records, we discovered that almost all thirty-six counties in the state of Oregon had referred girls to the Louise Home in the last year. We therefore, decided to attempt to administer the questionnaire to all counties in Oregon.

The third step in the methodology was to contact al1 Children's Services Division district directors in Oregon to find out from these Individuals how many C.S.D. workers were involved in the referral of adolescent girls to treatment centers. Children's Services Division offers Its services through county agencies. A district director has administrative responsibility for a Children's Services 
Division county agency or for a combination of counties in the same geographical area.

We wanted to explain our questionnaire to the directors and to gain insight from them about the counties' individual manner of handling referrals. We also wanted to get each director's assistance in administering the questionnaires. Moreover, we wanted the C.S.D. administrators to realize that we had the approval of the Louise Home in doing this research.

Thus, we asked Guy Hancock, the director of the Louise Home to write a letter (see Appendix II) which could be sent to all C.S.D. district directors. The letter was to briefly explain the nature of the research, and to inform the directors that we would be making phone contact with them in November. Mr. Hancock wrote the letter and in it stated that we would be making phone contact with the directors in November 1973. The letter explained that one of us would be calling to find out who in each office could initiate a referral to Louise Home. We also would ask if the referral must be authorized, and if so, by whom. The purpose of these questions was to find if the referral process differed among the various county offices. By asking these questions we found out the following information about the counties 1isted:

County

Coos, Curry

Clackamas

Jefferson, Crook

\section{Referral Information}

Caseworkers initiate referral and make direct contact with Louise Home:

Court 1laison worker Caroline Wilson and caseworkers may initiate referrals and contact Louise Home directly.

Referrals are initiated by caseworkers and then staffed by a review committee composed of supervisor, two caseworkers and a juvenile court worker. 
County

Rlamath; Lake

Model Cities

Union, Baker, Grant

Washington

West Multnomah
Referral Information

Al1 caseworkers can initiate referrals. However, the final decision about placement in the Louise Home is made by the placement committee. There is a liaison worker for Louise Home.

Potentially any caseworker can inftiate a referral and it does not have to be authorized by anyone else.

Caseworkers collaborate with supervisor regarding placement of a girl at Louise Home. They also may consult with juvenile court and mental health staff.

In this county Ceciley Lang handles all referrals to the Louise Home.

This county has a liaison worker for the Loulse Home. However the decision regarding placement is made by the caseworker referring.

We gathered this information from our phone conversations with the district directors. By the end of January we had made phone contact at least once with each district director. Most of them were willing to cooperate with us and to assume the responsibility of administering and returning to us the questionnaires which we wanted to send to them.

Multnomah County although, presented some unique questions. Multnomah County has the largest population of all the counties. Consequently it is subdivided into five sections with a district director for each. These subdivistons are East Multnomah, Model Cities, Northeast, Southeast and West Multnomah County.

The district director for Southeast did not want to assist us at first because this person was concerned that our study might interfere with a study C.S.D. was planning to do. The proposed C.S.D. study was to evaluate all the child-caring agencies in Oregon. After further deliberations, this director decided that administering our questionnaires to the caseworkers in the Southeast office would not bias 
the workers for the later-planned C.S.D. study. Thus the director did permit us to send the questionnaires to that office. The directors of Northeast and Model Cities both sald we could send them questionnaires. We did, but no questionnaires from either office were returned.

In total, the return of the questionnaires from the counties was 144. 299 questionnaires were mailed. Thus $48 \%$ of the questionnaires sent were returned. This high percentage of return may be attributed to: one or more of the following factors:

1. The letter of introduction sent by Guy Hancock to the district directors.

2. The initial phone calls to each district director.

3. The follow-up letter mailed out with the questionnaire. (See Appendix III)

4. $\therefore$ The follow-up phone calls between February 15 th and February 22nd to all counties who had not yet sent back their questionnaires.

5. The efforts each district director put into administering and returning the questionnaires.

Some directors are responsible for a single large county, while others are responsible for a combination of counties: When mailing out the questionnaires to the counties, we sent the total number of questionnaires requested. For example; the director of Klamath and Lake Counties requested sixteen questionnaires. We coded the questionnaires in this manner--numbers 65 to 81 were sent to Klamath and Lake Counties. However, we did not devise a method to distinguish in the return which questionnaires represented Lake and which Klamath. of the sixteen questionnaires sent, the director returned six. Thus the questionnaires returned represent the total return for the combination of countles. But if we wanted to determine whih questionnaires of the six returned represented Lake, and Which Klamath, we could not. This was a flaw in our methodology. 
In the next chapter, we will be analyzing the results of this research in two ways. We will first be looking at the results from the standpoint of the total sample to see if there are any significant areas of concern in all counties. Secondly; we wl11 break down the data by county in order to determine if opinions effect the number of referrals in each county. This will also be done to individualize the concerns of each county. Thus the Louise Home may get an Idea of the specific needs of each county which are either being or not being met at the current time. Hopefully, this will lead to a more effective Individualized approach toward serving each county. 
CHAPTER III

DATA ANALYSIS

$\ldots$ 
This section involves: 1) a presentation of the statistical plan; and 2) a compilation and analysis of the results of the study itself. The first part will outline the statistical manipulations and criteria to be utilized on the data collected. The second part will summarize the findings and examine their significance.

\section{STATISTICAL PLAN}

In PART I of the questionnaire there are seven questions concerning referral information. For question one we planned to run a simple frequency count to determine how many answered "yes" or "no"; and how many of each of these filled out the rest of the questionnaire or not. For statistical purposes we decided that we would use only those questionnaires from each county which answered "yes" to this first question and also filled out the questionnaire. These "yes and completed" questionnaires are herein referred to as the "total sample", and correspond to all the "yes . and completed" questionnaires from all the counties considered as a whole. Notably when we are considering only those "yes and completed" questionnaires from a particular county, we will refer to them as that respective "county sample". In addition, we kept separate; for comparison purposes, those questionnaires on which the individual answered "no" to the first question and still filled out the questionnaire. These questionnaires taken from all the counties as a whole will be referred to herein as the "no's sample". For questions two through five we planned for the total, counties, and no's sample to compute the sum of the cases listed in each of the four categories; 1) possible referrals; 2) actual referrals; 3) Louise Home referrals; and 4) Louise Home acceptances. For 
question six.we decided, because the number referred to the other centers was not asked for, it was only possible to compute the frequency and percent each center was listed for the group being studied. For question seven we simply wanted to compute the average (mean) number of months the individuals in each sample were in a position to refer girls to the Louise Home.

In PART II of the questionnaire concerning the attitudinal survey, it was decided that for all twenty-eight questions the mean, mode and standard deviation as well as a frequency tally would be computed and run for each county, the tota1, and the no's samples. From this Information it would be possible for us to determine around which of the five responses to each statement the samples were grouping themselves and to what degree.

For both parts of the questionnaire together we decided to run a "regression analysis" for correlations between all the questions, demographic and attitudinal, with the exclusion of questions one and six in PART I. Our purpose for running this particular analysis was threefold: 1) we wanted to find out if there was any relation between the referral information gathered in Part $I$ and the attitudes surveyed in Part II; and especially whether the number of persons referred to the Louise Home and the length of time in a position to make referrals affected a person's attitudes about the Louise Home; 2) we wanted to check out our two test questions ( 9 and 14) on the recreation program at the Louise Home to see if the respondents were answering consistently throughout the questionnaire; and 3) we wanted to see if there were any surprise correlations we hadn't anticipated. 
In order to make inferences from our results we also decided to determine besides the above statistical indicators, certain criteria of significance for both the attitudinal indicators (mean, mode, and standard deviation); and the correlational indicators (coefficients): For the major attitudinal indicators of mean and standard deviation, we divided them into parts for such purposes of analysis. The mean response was to be divided into seven parts or groupings of scores: 1) 1.00 to 1.99; 2) 2.00 to 2.49 ;3) 2.50 to $2.99 ;$ 4) 3.00 ; 5) 3.01 to $3.50 ; 6$ ) 3.51 to $4.00 ;$ and 7$) 4.01$ to 5.00

These seven parts or grouplngs of the mean scores range by degree from strongly agree through neutral to strongly disagree, or in other words, through the full range of the Likert type scale used in the attitudinal survey. Because the mean is a measure of "typical value" or "central tendency" a score placed on the above scale Indicates around which response the sample taken tended to group itself. For example, using the seven part scale proposed, a mean score in the first grouping ( 1.00 to 1.99$)$ would indicate a tendency to strongly agree with the statement; in the second grouping $(2.00$ to 2.49$)$ a tendency to agree; in the third $(2.50$ to 2.99$)$ a tendency to be neutral but slightly agree; In the fourth $(3.00)$ to be mostly neutral; in the fifth ( 3.01 to 3.50) a tendency to be neutral but slightly disagree; in the sixth (3.51 to 4.00$)$ a tendency to disagree; and in the seventh $(4.01$ to 5.00$)$ a tendency to strongly disagree.

The standard deviation on the other hand was to be divided into four parts: 1) $.000 ; 2) .001$ to $.500 ; 32.501$ to .750; 4) .751 to 1.000; and 5) 1.001 to $2.700 ; 2.70$ being the greatest standard deyiation possible. 
Because the standard deviation is a measure of dispersion, it Indlcates how spread out the scores are from the mean, or in this case, how much variability in response to the statement exists. For example; a mean score of 3.00 with a standard deviation of .500 would Indicate that $68 \%$ of the scores are within the range of 2.50 and 3.50 , or that most of the respondents felt neutral about the statement; while the same mean score with a standard deviation of 1.000 would indicate that $68 \%$ of the scores are with the range of 2.00 and 4.00 , or that one-third of the respondents tended to agree and the other disagree with the statement. Therefore, the smaller the standard deviation the more centralized the scores are around the mean; and the greater the standard deviation the more scattered they are. The five categories of the standard deviation proposed for this study move then from a more to a less centralized tendency, .000 to 2.70 .

By. juxtaposing these two proposed scales of the variations in the means and standard deviations in a table (see Table I) we felt it would be possible to make the needed inferences about the responses to each of the attitudinal questions for the groups sampled by determining where each question would be placed on the resulting grid. It would therefore be possible to discover to some extent whether the question was agreed or disagreed with and to what degree for each of the sample groups.

Lastly, with regard to the correlation indicators, we also needed to outline some criteria of significance. The major accepted way of determining the degree of co-yariability between variables is to find out at what point the correlation coefficient ( $r$ ) is significant at the .05 and .01 level of confidence. But because of 
our large total sample size $(N=128)$, and the resulting large number of "degrees of freedom" any correlation coefficient ( $r$ ) greater than .170 was significant at the .05 level of confidence; and any ( $(r)$ greater than 220 was significant at the 01 level. As a result if $\left(r^{2}\right)$ is computed; and therefore the proportion of the vartance in the one variable that is explained by the variation in the other variable is determined, only $3 \%$ and $5 \%$ respectively of the change In the response to one question on the questionnaire would be accounted for by another at these levels of significance (.170 and 220) : We decided then to consider important only those correlations whose coefficients ( $r$ ) were above 500 and would account for at least $25 \%$ or more of the variation in the two items correlated. 


\section{RESULTS}

This section will be divided into two parts. The first part w111 look at the findings from the "total sample", while the second W11 examine the findings from each of the individual "county samples". Total'Sample:

In looking at the results of the "total sample" we will explore: 1) the referral information; 2) the attitudinal survey responses; 3) the Inter-question correlations; and 4) the differences in attitudes, if any, between those who were and were not involved in the referral of girls to the Louise Home.

The referral information for the "total sample" can be found at the top of Table I, page 21. From this data it is apparent that of the potential number of girls $(12-18)$ who could possibly benefit from residential treatment in 1973 , only approximately $70 \%$ actually got referred. of this $70 \%$ nearly one-third were referred to the Louise Home.' But, importantly, the Louise Home only accepted a little over half $(65 \%)$ of those girls actually referred to it. As far as where else the other two-thirds of the girls were being referred, it is apparent that $41 \%$ of those who referred girls to the Louise Home also referred girls to Villa St. Rose. The only other significant referral alternatives were Christy Home (15\%); Chehalem House (11\%); and "other" (18\%). It is also important to note that approximately $53 \%$ of the "total sample" did not 11st any other places of referral in answer to question number six in PART I of the questionnaire. An added fact in the referral information is that the average length of time a CSD worker has spent in a position to refer girls to the Loufse Home Is three years. The results of the attitudinal suryey (PART II) responses for 
TABLE I : RESULTS

FROM THE TOTAL SAMPLE (COUNTY)

PART I: REFERRAL INFORMATION

\begin{tabular}{|l|c|c|} 
& Number & $\begin{array}{l}\% \text { of } \\
\text { Total }\end{array}$ \\
\hline $\begin{array}{l}\text { Total Possible } \\
\text { Referrals }\end{array}$ & 536 & 100 \\
\hline $\begin{array}{l}\text { Number Actually } \\
\text { Referred }\end{array}$ & 385 & $72 \%$ \\
\hline $\begin{array}{l}\text { Number Referred } \\
\text { to Louise Home }\end{array}$ & 131 & $24 \%$ \\
\hline $\begin{array}{l}\text { Number Accepted } \\
\text { at Louise Home }\end{array}$ & 85 & $16 \%$ \\
\hline
\end{tabular}

Length of Stay Average/Per. In Position to 36 Months

$$
\underline{N}=128
$$

\begin{tabular}{l|l|l} 
& $\begin{array}{l}\text { Number } \\
\text { Listed }\end{array}$ & $\begin{array}{l}\% \text { of } \\
\text { Total }\end{array}$ \\
\cline { 2 - 3 } Vi1la St. Rose & 52 & 41 \\
\hline Farm Home & 13 & 10 \\
\hline Christy & 19 & 15 \\
\hline Youth Adventures & 10 & 7.8 \\
\hline Hillcrest & 5 & 3.9 \\
\hline White Shie1d & 4 & 3 \\
\hline Youth Care Center & 5 & 3.9 \\
\hline Chehalem House & 14 & 11 \\
\hline Boys \& Girls Aide & 2 & 1.5 \\
\hline Valadera & 4 & 3 \\
\hline Other & 23 & 18 \\
\hline No Response & 68 & 53 \\
\hline
\end{tabular}

\section{PART II:ATTTTUDINAL SURVEY}

MEANS

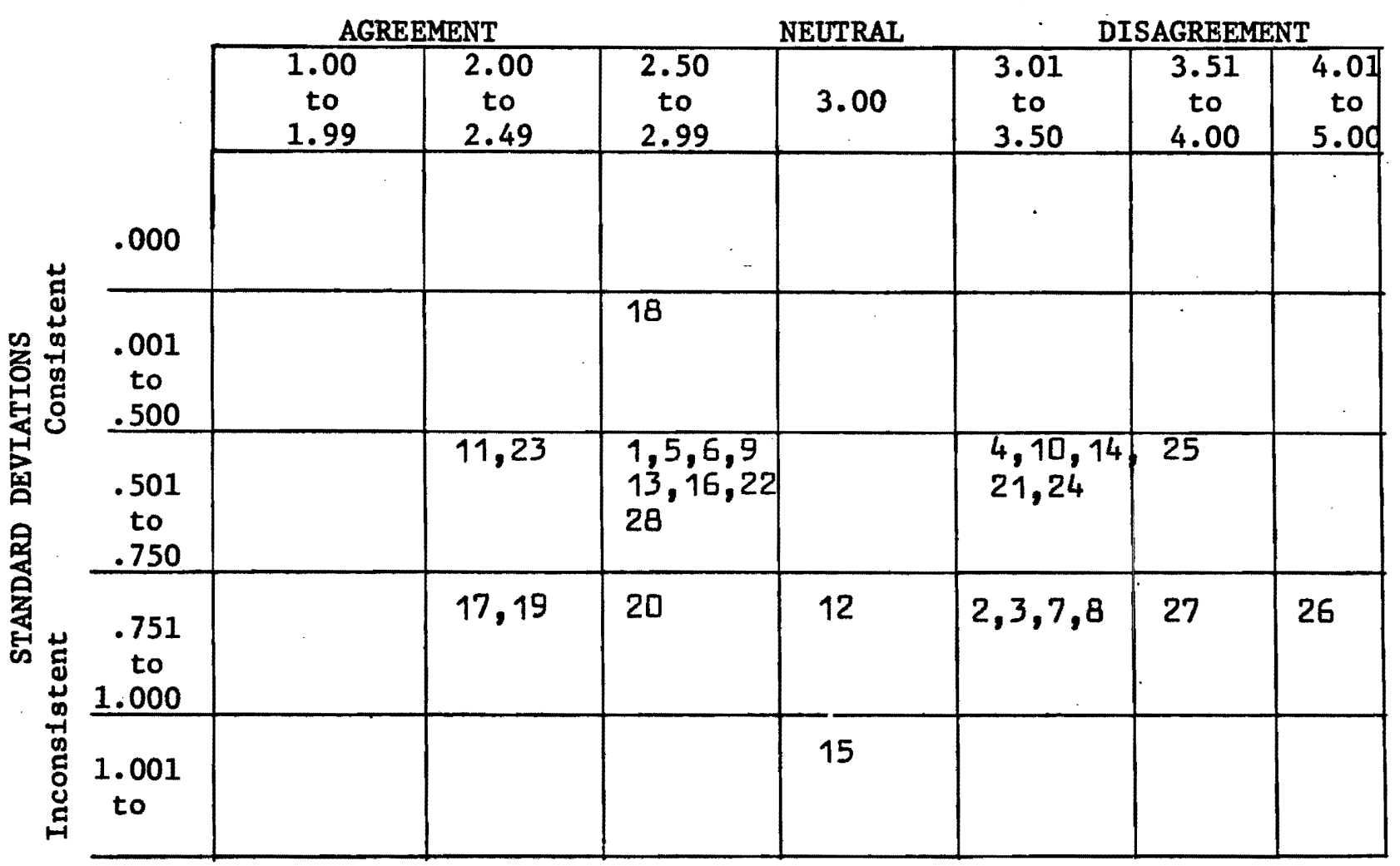


the "total sample". can also be found in :Table I page 21 . From this means and standard deviation"grid" it is apparent that the "total sample". tended to fairly consistently agree vith questions 11 and 23 , and disagree with question 25 ; and less consistently agree with questions 17 and 19 , and disagree with questions 27 and especially 26 . In other words, the sample tended to agree that: 1) visits by friends and relatives to the Louise Home are usually a part of a girl's treatment program; 2) the school program is good; 3) runaways are a problem; and 4) pre-placement visits to the Loulse Home are valuable; and it tended to disagree that; 1) the Louise Home is too far away to consider as a resource; and 2) there are adequate and more convenient resources for teenage girls who would be eligible for the Loulse Home program within our own community. As for the rest of the questions, the majority of them are in the generally neutral area, only slightly agreeling or disagreeing with the statements. For example, there was a slight tendency to agree with questions $1,5,6,9,13,16,22$ and 28, or agree that: 1) the organizational structure facilitates the Louise Home's operation; 2) the caseworkers do an adequate $j \circ b$, and the child care workers are competent; 3) the recreation program is an asset; 4) the Louise Home provides an effective residential treatment program; 5) the staff are in control; 6) the girls medical needs are met sufficiently; and 6) there are more girls to refer to the Louise Home during the school year; and a slight tendency to disagree with questions $4,10,14,21$ and 24 , or that: 1 ) the administration does not provide effective leadership; 2) that the girls at the Louise Home have too much freedom; 32 that the recreation program is not a valuable part of the program; 42 there is good follow-up of girls after release; and 5) the Louise Home places too great an emphasis 
on religion. As for questions $20,2,3,7$ and 8 , they also, for the most part, were responded to neutrally, only slightly agreeling or disagreelng, but they did so even less consistently (with more variation) than the previous group 1isted, and so won't be mentioned here.

As a last point, in looking at the attitudinal responses for the "total sample", there is question 15: "It is vague what type of girl should be referred to the Louise Home." Although the mean for this question is 3.00 , the standard deviation is 1.018 indicating a wide spread in the responses. Iooking at the tally sheet (Appendix IV), $6 \%$ of the sample strongly agreed with the statement; $30 \%$ agreed with 1t; $23 \%$ were neutral; $40 \%$ disagreed with it; and $2 \%$ strongly disagreed. It is apparent then, that there is a great deal of disparity of opinions around what type of girls who "should" be referred to the Louise Home.

TABLE II: TOTAL SAMPLE CORRELATION COEFFICIENTS $\left(r \& r^{2}\right)$

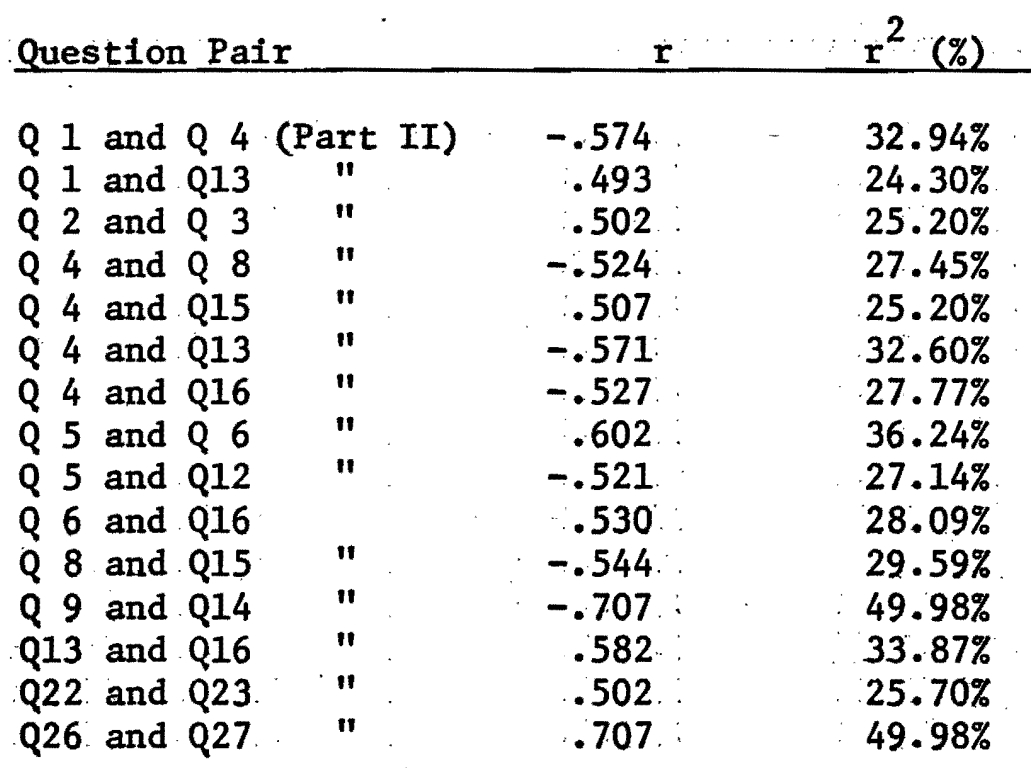


Although we have listed in Table II (see page 23) the significant correlations with a $\left(r^{2}\right)$ greater than 250 , our most important finding from running the "regression analysis" was that there was seemingly no significant correlation of any magnitude between the referral information and the attitudes surveyed. The number of referrals to the Louise Home, and the length of stay in a position to refer to the Louise Home, were consistently not correlated to any attitudes about the Louise Home per se. "The other Important finding was that our two test questions on recreation at the Louise Home correlated negatively as expected; and at a level $\left(r^{2}\right)$, which accounted for nearly $50 \%$ of the co-variation. As for the rematning question pairs in the table, they indicate the following: 1) that attitudes about effective administrative leadership (Q.4) are correlated positively with those about a clear treatment philosophy (Q.8), a "non-vague" Idea of what kind of girl to refer to the Louise Home (Q.15), an over-all effective residential treatment center $(Q .13)$, staff control $(Q .17)$, and an organizational structure that facilitates program operation $(Q .1) ; 2)$ that attitudes about an adequate job of casework (Q.5) at the Louise Home are positively correlated with those concerning competent child-care workers $(Q, 6)$, and well planned home-visits $(Q .12) ; 3)$ that attitudes about the difficulty communicating with the Louise Home $(Q .2)$ are positively correlated to those referring to inconveniences in the intake process $(Q .3)$; 4) that attitudes about staff control (Q.16) at the Louise Home are positively correlated with those competent child-care workers $(Q .6) ; 5)$ that attitudes about a clear treatment philosophy (Q.8) are positively correlated with those of not vaguely knowing what kind of girl to refer to the Loulse Home $(Q .15) ; 6)$ that 
TABLE III : RESULTS

FROM THE NO'S SAMPLE ( COUNTY)

PART I: REFERRAL INFORMATION

\begin{tabular}{|l|c|c} 
& Number & $\begin{array}{l}\text { \% of } \\
\text { Total }\end{array}$ \\
\hline $\begin{array}{l}\text { Total Possible } \\
\text { Referrals }\end{array}$ & 2 & 100 \\
\hline $\begin{array}{l}\text { Number Actually } \\
\text { Referred }\end{array}$ & 2 & 100 \\
\hline $\begin{array}{l}\text { Number Referred } \\
\text { to Louise Home }\end{array}$ & 0 & 0 \\
\hline $\begin{array}{l}\text { Number Accepted } \\
\text { at Louise Home }\end{array}$ & 0 & 0 \\
\hline
\end{tabular}

Length of Stay in Position to Refer Girls
Average/Per.

43 Months
$\underline{N}=\underline{16}$

\begin{tabular}{l|c|c} 
& $\begin{array}{c}\text { Number } \\
\text { Listed }\end{array}$ & $\begin{array}{c}\% \text { of } \\
\text { Total }\end{array}$ \\
\cline { 2 - 3 } Villa St. Rose & 1 & 6 \\
\hline Farm Home & 1 & 6 \\
\hline Christy & 1 & 6 \\
\hline Youth Adventures & & \\
\hline Hillcrest & & \\
\hline White Shield & & \\
\hline Youth Care Center & 1 & 6 \\
\hline Chehalem House & & \\
\hline Boys \& Girls Alde & & \\
\hline Valadera & & \\
\hline Other & & \\
\hline No Response & 13 & 81 \\
\hline
\end{tabular}

\section{PART II:ATTITUDINAL SURVEY}

\section{MEANS}

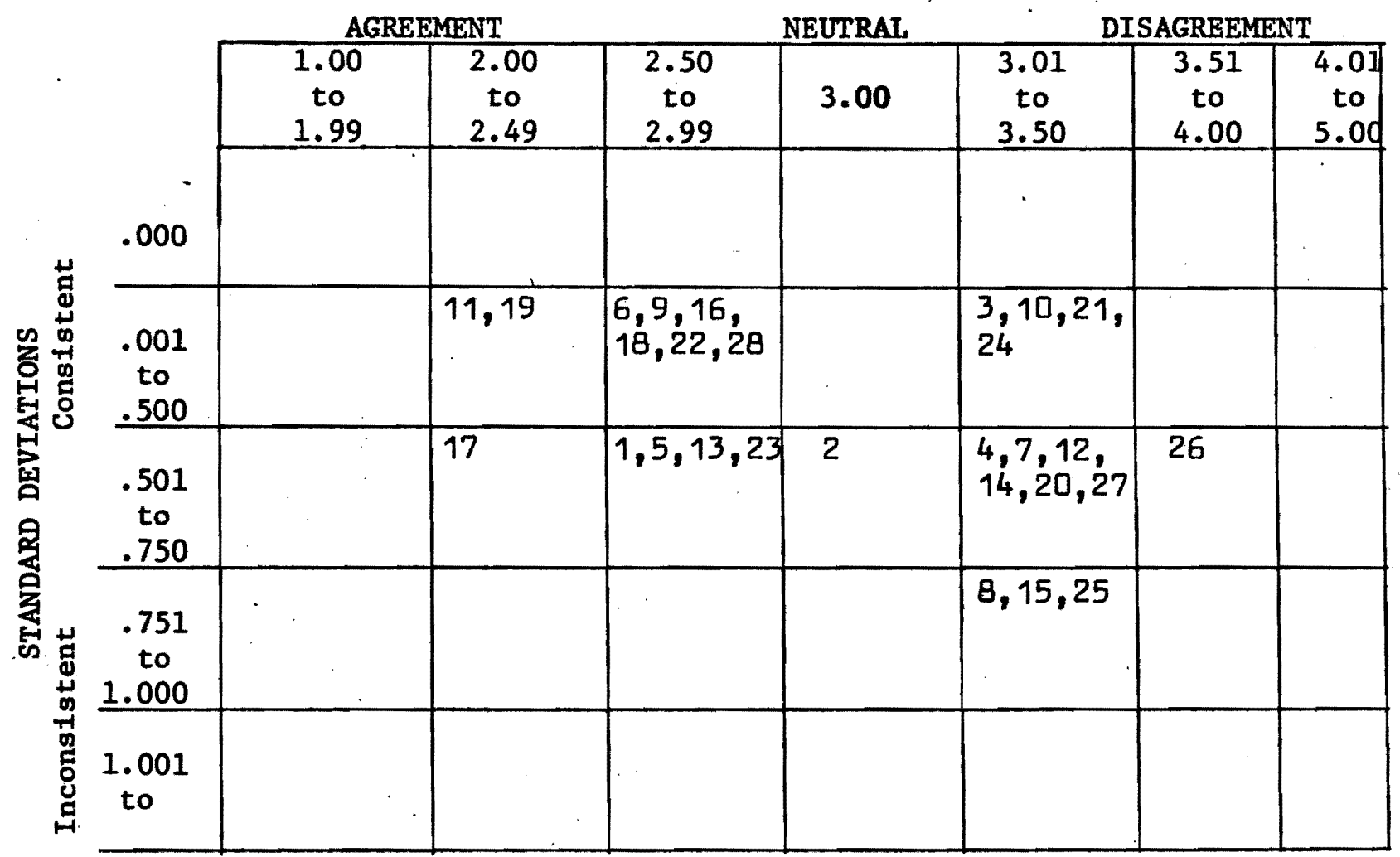


attitudes about the effectiveness of the Louise Home's residential treatment program $(Q, 13)$ are positively correlated with those of staff control $(Q .16)$; and 7$)$ that attitudes about adequate $(Q .26)$ and conventent (Q.27) resources for teenage girls in the local communities are positively correlated.

The last area of analysis of the "total sample" is its comparison to the "no's sample" (see Table III, page 25), previously described in the statistical plan. Because the "no's sample" is so small (N=16) compared to the "total sample" Inferences must be made cautious and generally. The most striking difference between the "total and the no's sample" is the average length of time spent in a position to refer to the Louise Home. The average for the "no's sample" was over one-half year longer than the "total sample". . As for the attitudinal responses, it can be said that the "no's sample" tended to be less extreme and scattered in its responses than the "total sample"; but still tending to vary on some of the same key questions $(11,19,17$ and 26$)$.

\section{County Samples:}

The analysis of each individual county will take somewhat the same form as that for the "total sample" with the exception that there will be no correlations to consider or "no's sample" to compare to; and the examinations of the attitudinal results will only focus on the most obvious tendencies due to the large number of counties to analyze.

Baker County (see Table IV, page 27)

The most striking fact from the referral information from Baker County is that they refer $92 \%$ of their actual referrals to residential treatment centers to the Louise Home; and that $73 \%$ of these referrals 
TABLE IV : RESULTS

FROM BAKER COUNTY

PART I: REFERRAL INFORMATION

$\underline{N}=-6$

\begin{tabular}{|l|c|c|} 
& Number & $\begin{array}{l}\text { \% of } \\
\text { Total }\end{array}$ \\
\hline $\begin{array}{l}\text { Tota1 Possible } \\
\text { Referrals }\end{array}$ & 16 & 100 \\
\hline $\begin{array}{l}\text { Number Actually } \\
\text { Referred }\end{array}$ & 12 & 75 \\
\hline $\begin{array}{l}\text { Number Referred } \\
\text { to Louise Home }\end{array}$ & 11 & 69 \\
\hline $\begin{array}{l}\text { Number Accepted } \\
\text { at Louise Home }\end{array}$ & 8 & 50 \\
\hline
\end{tabular}

\begin{tabular}{l|c|c}
\multirow{2}{*}{ Villa St. Rose } & $\begin{array}{l}\text { Number } \\
\text { Listed }\end{array}$ & $\begin{array}{c}\% \text { of } \\
\text { Total }\end{array}$ \\
\cline { 2 - 3 } & 1 & 16 \\
\hline Farm Home & & \\
\hline Christy & 1 & 16 \\
\hline Youth Adventures & & \\
\hline Hillcrest & & \\
\hline White Shield & & \\
\hline Youth Care Center & & \\
\hline Chehalem House & & \\
\hline Boys \& Girls Aide & & \\
\hline Valadera & 1 & 16 \\
\hline Other & 1 & 16 \\
\hline No Response & 3 & 50 \\
\hline
\end{tabular}

Length of Stay in Position to Refer Girls

Average/Per. 34.33

\section{PART II:ATTITUDINAL SURVEY}

MEANS

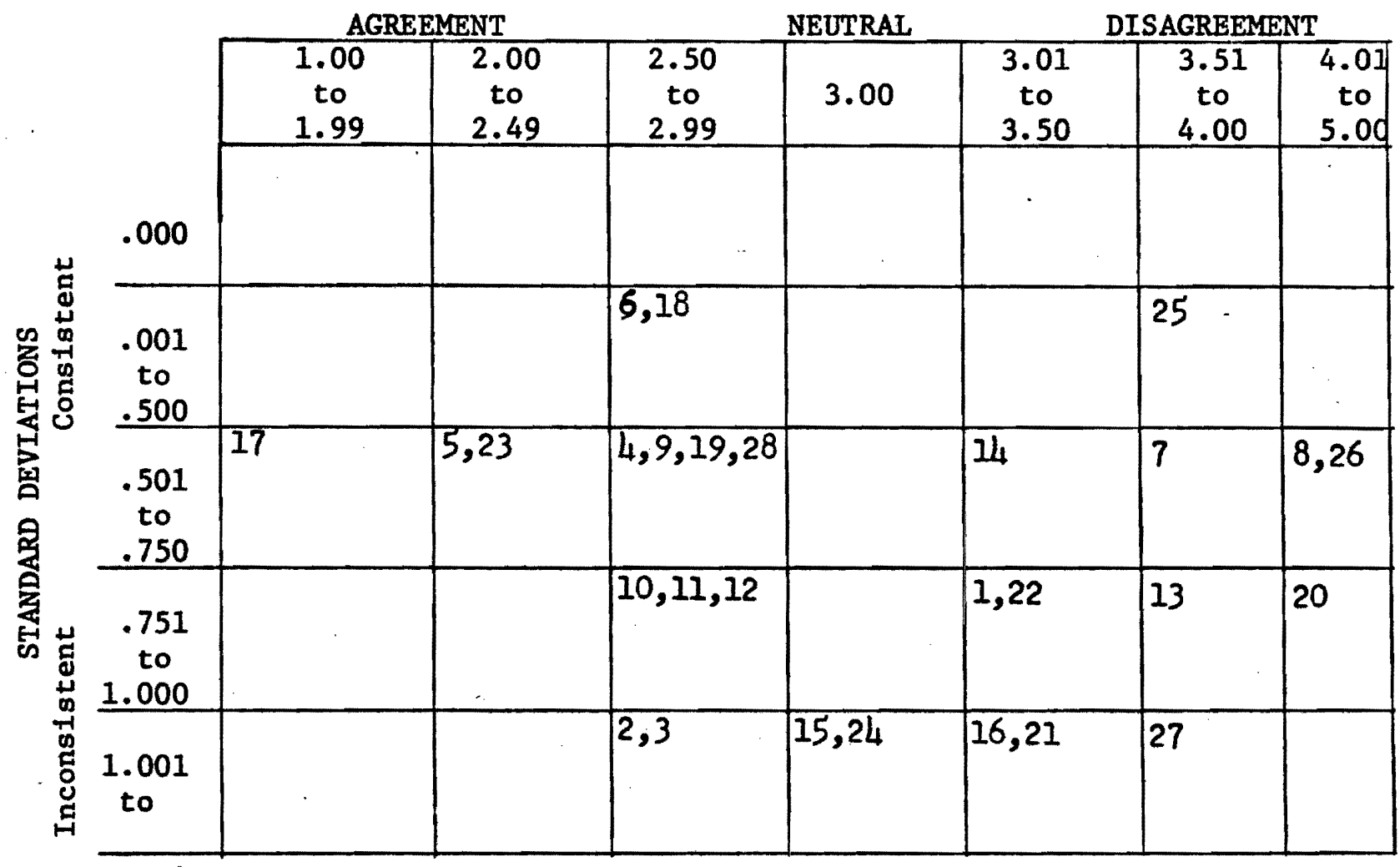


are accepted. Considering its attitudinal data it is apparent that there are large differences and extremes of opinfons. There is fairly conststent agreement with statements 5,23 , and espectally with 17; or agreement: 1) that caseworkers at the Loufse Home do an adequate job; 2) that the school program is good; 3) that runaways are a problem (strongly agree). There is fairly consistent disagreement with statements 25 , and 7 ; and less consistently with 13 and 27 ; or disagreement that: 1) the Loulse Home is too far away to consider as a resource; 2) the physical facilities are below standard; 3) the Louise Home provides an effective residential treatment program; and 4) there are more convenient resources locally, respectively. In addition, there Is also "strong disagreement" with statements 20,8 , and 26 , or disagreement that: 1) release of girls from the Louise Home 1s well planned; 2) the Loulse Home philosophy is clear; and 3) there are adequate resources locally for residential treatment. The remainder of the questions tend for the most part to be neutral.

\section{Comments from Baker County}

"I have referred three girls to the Louise Home in 1973; two were accepted. One of the girls was rejected as being too emotionally disturbed. Both accepted referrals were terminated from the program within three months due to runaway behavior. The last girl stated after termination that 'she knew that if she ever ran and was gone past during which CSD payment continued that she would be terminated from the Louise Home program.' Since there are many more referrals than the three from our county, it is difficult to develop a statement of program effectiveness, but from our experience the Louise Home's batting ayerage in the last year was zero."

"The Louise Home policy of termination of runaways is not consistent in my experiences. The program should be able to deal effectively with extremes of 'runaway behayior.!" 
"We have a group foster home here wich seems to do a hetter job of relating to the girls and treating them than Louise: Howeyer, it is not considered a residential treatment center. Louise has refused to take two girls I haye In my caseload. One was refused this year and one previously. Both have problems which could benefit from such a center, but evidently these problems were too severe for Louise to handle. The girl who was In my caseload and placed there ran away often and was told by Louise she couldn't come back the last time. She told me she had run because Louise would then kick her out. They played her game we11. I have previously been acquainted with residential treatment centers in another state as well as here in Oregon: I would not refer another girl to Louise unless I was desperate."

"I have the impression Louise Home is more concerned about ADP and budget than individual treatment plans on girls. Termination procedure of ten expedient without involving referring agency and family. Joint input from the referring county in our situation on occasion has been disallowed. Intake information is inconsistent. Public relations meetings with Louise staff has promised much, program has not produced. It appears C.S.D. often ends up with foster parents, and group homes having to do a treatment job with less money and resources on kids Louise Home has falled with. After the last referral we made to Louise Home, who was terminated in our view inappropriately and now is in our group home, Loulse Home Is not a first choice for residential treatment."

"I am not all that familiar with Louise Home's program, thus all of the neutral answers. The intake procedure is inconvenient because of the pre-placement visits and we are on the other side of the state. I feel this should be taken into account with Eastern Oregon counties.".

Clackamas County: (see Table V, page 30)

Examining the referral information from Clackamas County there are two significant facts: 1) that they only refer approximately one-fourth of their actual referrals to the Louise Home; and that of these the Louise Home accepts less than half; and 2) their ayerage length of time in a position of referral is over 13 months longer than the average for all counties. As for alternative residential treatment centers 1isted, $31 \%$ 1isted Villa St. Rose and "other", and 19\%. 1isted Christy Home. 


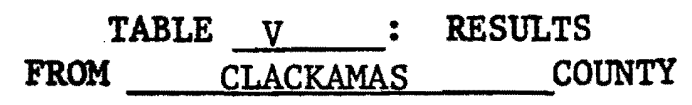

PART I: REFERRAL INFORMATION

$\underline{N}=\underline{16}$

\begin{tabular}{|l|c|c|} 
& Number & $\begin{array}{l}\text { \% of } \\
\text { Total }\end{array}$ \\
\hline $\begin{array}{l}\text { Total Possible } \\
\text { Referrals }\end{array}$ & 49 & 100 \\
\hline $\begin{array}{l}\text { Number Actually } \\
\text { Referred }\end{array}$ & 31 & 63 \\
\hline $\begin{array}{l}\text { Number Referred } \\
\text { to Louise Home }\end{array}$ & 8 & 16 \\
\hline $\begin{array}{l}\text { Number Accepted } \\
\text { at Louise Home }\end{array}$ & 3 & 6 \\
\hline
\end{tabular}

\begin{tabular}{l|c|c}
\multirow{2}{*}{ Villa St. Rose } & $\begin{array}{l}\text { Number } \\
\text { Listed }\end{array}$ & $\begin{array}{l}\% \text { of } \\
\text { Total }\end{array}$ \\
\cline { 2 - 3 } & 5 & 31 \\
\hline Farm Home & & \\
\hline Christy & 3 & 19 \\
\hline Youth Adventures & & \\
\hline Hillcrest & & \\
\hline White Shield & 1 & 6 \\
\hline Youth Care Center & & \\
\hline Chehalem House & & \\
\hline Boys \& Girls A1de & & \\
\hline Valadera & & \\
\hline Other & 5 & 31 \\
\hline No Response & 7 & 43 \\
\hline
\end{tabular}

\section{PART II: ATTUDINAL SURVEY}

MEANS

\begin{tabular}{|c|c|c|c|c|c|c|c|}
\hline \multirow[b]{3}{*}{.000} & \multicolumn{3}{|c|}{ AGREEMENT } & NEUTRAL & \multicolumn{3}{|c|}{ DISAGREEMENT } \\
\hline & $\begin{array}{c}1.00 \\
\text { to } \\
1.99 \\
\end{array}$ & $\begin{array}{c}2.00 \\
\text { to } \\
2.49 \\
\end{array}$ & $\begin{array}{c}2.50 \\
\text { to } \\
2.99 \\
\end{array}$ & 3.00 & $\begin{array}{c}3.01 \\
\text { to } \\
3.50 \\
\end{array}$ & $\begin{array}{c}3.51 \\
\text { to } \\
4.00 \\
\end{array}$ & $\begin{array}{r}4.01 \\
\text { to } \\
5.00 \\
\end{array}$ \\
\hline & & & & 12 & . & & \\
\hline 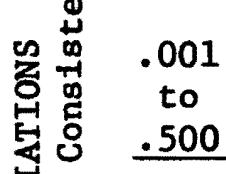 & & $6,11,13$ & 18,22 & & 21,24 & & \\
\hline $\begin{array}{c}.501 \\
\text { to } \\
.750 \\
\end{array}$ & 19 & $\begin{array}{l}1,5,16,17 \\
23\end{array}$ & 9,20 & & 4,10 & 14 & 25 \\
\hline 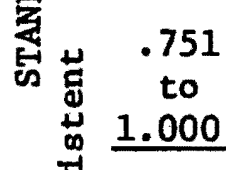 & & & & & $\begin{array}{l}2,3,7,8, \\
15\end{array}$ & & 26 \\
\hline 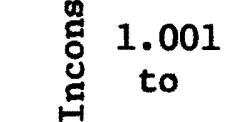 & & & & & & & \\
\hline
\end{tabular}


Considering the attitudinal data; there was fairly consistent agreement with statements $1,5,6,11,13,16,17,23$; and strong agreement with statement 19 ; or in other words; agreement: 1) that the organizational structure facilitates operation; 2 ) that the caseworkers and child care workers do an adequate and competent job, respectively; 3 ) that the Louise Home provides an effectiye residential treatment program; 4) that the staff are in control; 5) that runaways are a problem; 6) that the school program is good; and strong agreement that 7) pre-placement visits to the Louise Home are valuable. There was also consistent disagreement with statement 14, and strong disagreement with statements 25 and 26 ; or disagreement that "the recreation program is not a valuable part of treatment..."; and strong disagreement that "there are adequate and more convenient resources for teenage girls who would be eligible for the Louise Home within" their own community.

\section{Comments from Clackamas County}

"I have made only one referral to Louise Home. The girl was accepted for admittance, a pre-placement visit was made, but the home situation improved and she remained with her family. The referral process went smoothly, there was little delay: However; I have had no experience of working with Louise Home on any ongoing basis."

"Girls that I have worked with who have been through the Louise Home treatment program have more selfawareness and are able to take more responsibilities for their own actions."

"My workers (number six) have not met with particular difficulty with Louise Home, but rather have enjoyed fairly positive results from glrls placed there. Problem areas: 1) Runaways and lack of contracts between workers and girls at beginning of placement regarding this. 2) Lack of our agency's inyolyement with Louise staff once girl is placed. We recelve far more feedback than I feel we give input." " 


\begin{abstract}
"We don't : know enough about Louise to answer these questions - seems more appropriate: to give to Louise staff members:"

"The neutral response was used by me when I didn't haye any particular feelings and/or no information on which to base a response. Also, it's been some time since I'ye had any direct contact with its program."
\end{abstract}

Columbia County: (see Table VI, page 33 )

From the sample of Columbia County workers, it is apparent the Loulse Home received less than half of the referrals of eligible girls, and accepted even less (one-third). In addition, a little over half (57\%) 1isted Villa St. Rose as an additional place of referral. It is also notable that the average length of time spent in a "position of referral" is ten months below that for the "total sample":

The attitudinal responses for Columbia County tend to be scattered and less consistent than most, as can be seen by the large number of questions with standard deviations greater than .751 and oyer 1.000. For example, there was wide differences of opinion to questions $2,5,12$ and even 15 , even though they averaged a neutral response over all. In other words, there was disparity of attitudes: of whether the Louise Home was difficult to communicate with (2); of whether the caseworkers were competent (5); of whether home visits were we11 planned (12); or of whether it is yague what type of girl should be referred to the Louise Home. There were fairly consistent agreements with statements $11,19,16$ and less consistently with 3 ; or agreement; 1) that visits by friends and relatiyes are a part of the treatment program; 2) that pre-placement yisits. are: valuable; 3) that the staff are in control, and less consistent agreement that "the Intake process at the Louise Home : Is inconyenient".: 


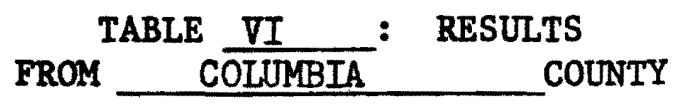

\section{PART I: REFERRAL INFORMATION}

\begin{tabular}{|l|c|c|} 
& Number & $\begin{array}{l}\% \text { of } \\
\text { Total }\end{array}$ \\
\hline $\begin{array}{l}\text { Total Possible } \\
\text { Referrals }\end{array}$ & 20 & 100 \\
\hline $\begin{array}{l}\text { Number Actually } \\
\text { Referred }\end{array}$ & 13 & 65 \\
\hline $\begin{array}{l}\text { Number Referred } \\
\text { to Louise Home }\end{array}$ & 6 & 30 \\
\hline $\begin{array}{l}\text { Number Accepted } \\
\text { at Louise Home }\end{array}$ & 2 & 10 \\
\hline
\end{tabular}

Length of Stay in Position to Refer Girls
Average/Per.

24.14 Months
$\underline{N}=\underline{7}$

\begin{tabular}{l|c|c} 
& Number & $\begin{array}{l}\% \text { of } \\
\text { Total }\end{array}$ \\
\cline { 2 - 3 } Listla St. Rose & 4 & 57 \\
\hline Farm Home & & \\
\hline Christy & & \\
\hline Youth Adventures & & \\
\hline Hillerest & & \\
\hline White Shield & & \\
\hline Youth Care Center & & \\
\hline Chehalem House & & \\
\hline Boys \& Girls Aide & & \\
\hline Valadera & & \\
\hline Other & 1 & 14 \\
\hline No Response & 3 & 14 \\
\hline
\end{tabular}

PART II:ATTITUDINAL SURVEY

MEANS

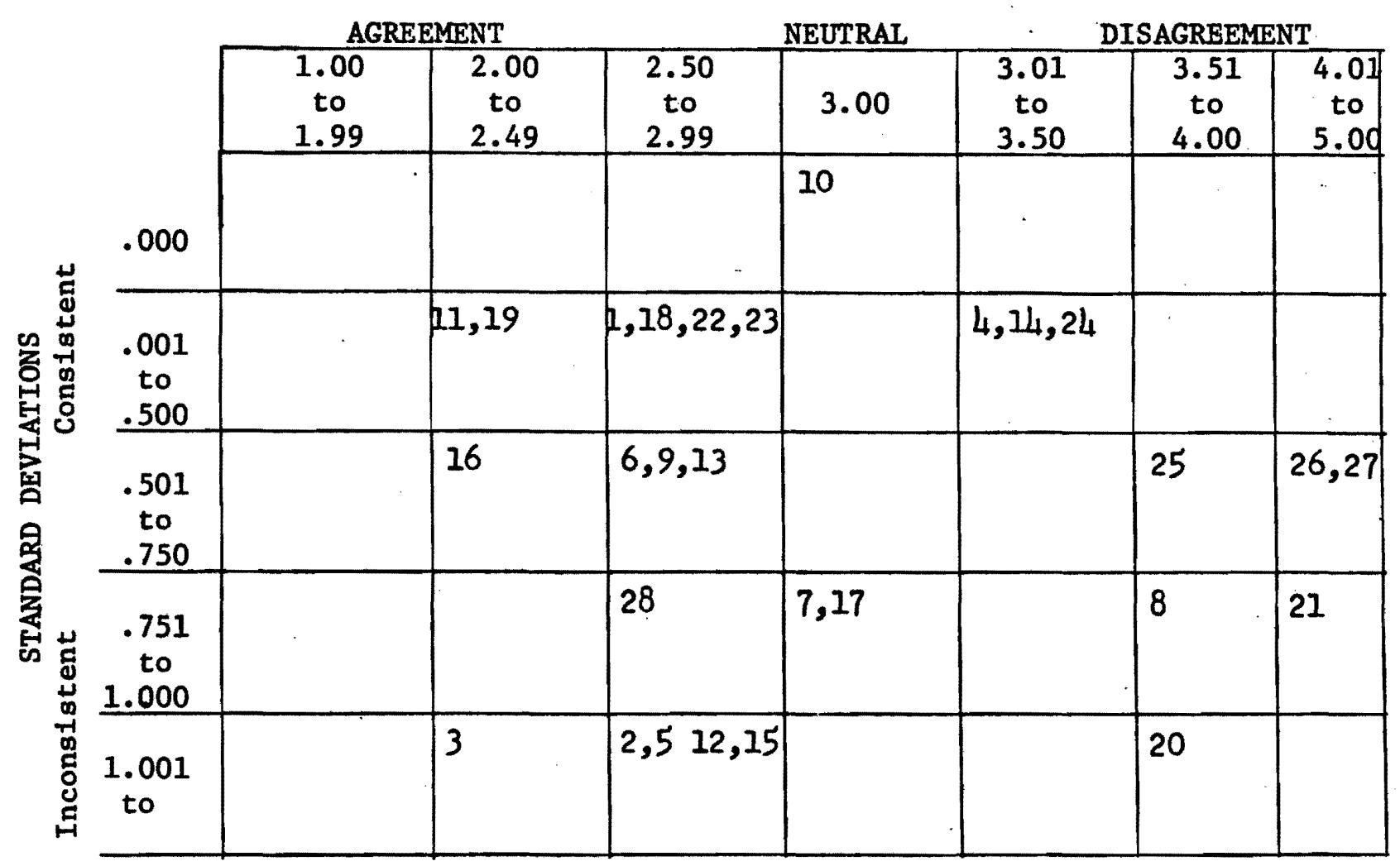


There was generally consistent disagreement with questions $25-27$, and less so with questions 8,21 and 20 ; or disagreement; 1 ) that the Louise Home is too far away to consider as a resource; 2) that there are adequate and more convenient resources locally for girls eligible for Loulse Home; and less conststent disagreement; 3 ) that the treatment philosophy of the Louise Home is : clear; 4) that the release of girls is well planned; and 5) that there is good follow-up of girls after release.

\section{Comments from Columbia County}

"My answers are based on the fact that I had one girl placed in Louise : Home. It was a case transferred to me from another worker after placement was made in 1972. My experience : in dealing with Loulse Home staff regarding this one situation was favorable. I feel that I am not acquainted well enough to be more than neutral in most instances. I was involved with this one client in planning her discharge from Louise Home."

Coos County (see Table VII, page 35 )

Because the sample from this county was only one person, the results will be individualized. This person referred one-half of his or her actual referrals to the Louise Home and had two-thirds of them accepted. He or she also listed referrals to Villa St. Rose, the Farm Home, Christy and Chehalem House.

Attitudinally this person agreed with statements $1,3,5,6,8$, $9,11,13,16,17,22,28$ and strong1y agreed with statements 19 and 23. In other words, he or she agree: 1) that the organizational structure facilitates Louise Home operation; 2) that the Intake process is inconyenient; 3) that the caseworkers do an adequate job;

3) that the child care workers are competent; 4) that the recreation 
program is an asset; $;$ ) that the Louise Home provides an effective residential treatment program; 6) that the staff are in control; 7) that runaways are a problem; 8) that the medical needs of the girls are met; 9) that there are more girls to refer during the school year; and strongly agreed that pre-placement visits are valuable, as well as that the school program is good. This person also disagreed with statements $4,7,110, \ldots 14, .15,25$; and strongly disagreed with statements $2,24,26$ and 27 . In other words, he or she disagreed: 1 ) that the administration doesn't provide effective leadership 2) that the physical facilities are below standard; 3) that the girls have too much freedom; 4) that it is vague what type of girl to refer to the Louise Home; 5) that the Louise Home is too far away to consider as a resource; and strongly disagreed: 1) that communication is difficult with the Louise Home; 2) that the Louise Home stresses religion too much; and 3) that there are adequate and more convenient resources for girls eligible for the Louise Home 1ocally.

Crook County (see Table VIII, page 37)

Because the sample from this county is only one person, the results will also be individualized. This person had only one actual referral to residential treatment and she did not refer this gir1 to the Louise Home. It is probably assured that she referred her to Villa St. Rose.

This person totally agreed with statements $6,9,11,12,17,22$, 23. and strongly agreed with statements 2 and 19. In other words, he or she agree: 1) that the child care workers are competent; 2) that the recreation program is an asset; 3) that visits by 
TABLE VIII : RESULTS

FROM CROOK COUNTY

PART I: REFERRAL INFORMATION

$\underline{N}=1$

\begin{tabular}{|l|c|c|} 
& Number & $\begin{array}{l}\% \text { of } \\
\text { Total }\end{array}$ \\
\hline $\begin{array}{l}\text { Total Possible } \\
\text { Referrals }\end{array}$ & $I$ & 100 \\
\hline $\begin{array}{l}\text { Number Actually } \\
\text { Referred }\end{array}$ & 1 & 100 \\
\hline $\begin{array}{l}\text { Number Referred } \\
\text { to Louise Home }\end{array}$ & 0 & 0 \\
\hline $\begin{array}{l}\text { Number Accepted } \\
\text { at Louise Home }\end{array}$ & 0 & 0 \\
\hline
\end{tabular}

\begin{tabular}{l|c|c} 
& $\begin{array}{l}\text { Number } \\
\text { Listed }\end{array}$ & $\begin{array}{l}\% \text { of } \\
\text { Total }\end{array}$ \\
\cline { 2 - 3 } Villa St. Rose & 1 & 100 \\
\hline Farm Home & & \\
\hline Christy & & \\
\hline Youth Adventures & & \\
\hline Hillcrest & & \\
\hline White Shield & & \\
\hline Youth Care Center & & \\
\hline Chehalem House & & \\
\hline Boys \& Girls Aide & & \\
\hline Valadera & & \\
\hline Other & & \\
\hline No Response & & \\
\hline
\end{tabular}

Length of Stay Average/Per. in Position to Refer Girls 14,00 Months

PART II:ATTITUDINAL SURVEY

MEANS

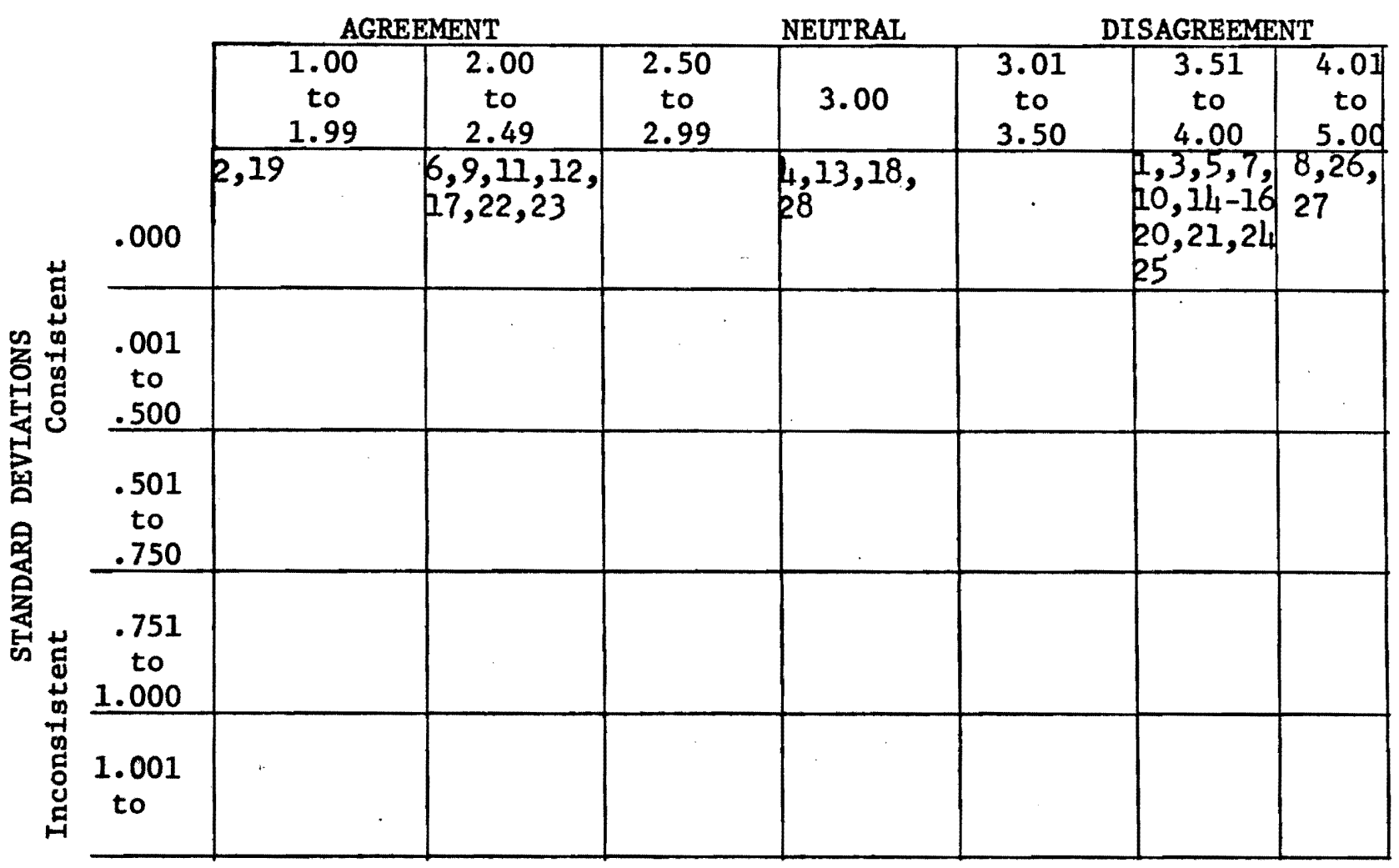


friends and relatives are treatment oriented; 4) that home visits are not well planned; 5) that runaways are a problem; 6) that the medical needs of girls are met sufficiently; 7) the school program Is good; and strongly agreed that it is difficult to commuicate with the Loulse Home, as well as that pre-placement yisits are valuable. This same person disagreed with statements $1,3,5,7$, $10,14,15,16,20,21,24,25$ and strongly disagreed with statements 8,26 and 27 . In other words, he or she disagreed: 1) that the organizational structure facilitates the Louise Home's operation; 2) that the intake process is inconyenient; 3) that the caseworkers do an adequate job; 4) that the physical facilities are below standard; 5) that the girls have too much freedom; 6) that the recreation program is not a valuable part of treatment; 7) that It is vague what type of girl to refer; 8) that the staff are in control; 9) that girls' releases are we11 planned; 10) that there is good follow-up after release; 11) that the Louise Home is too far away to consider as a resource; and strongly disagreed that the treatment philosophy is clear, and that there are adequate and more conventent resources locally.

Curry County (see Table IX, page 39)

Because the sample from Curry County again was one person, the results will be individualized. This person from Curry County referred $40 \%$ of her eligible girls to the Louise Home, all of which were accepted. This person also reported referring girls to Villa St. Rose, Farm Home, Christy and Chehalem House; and had been in such a position to refer girls for fiye years.

In the attitudinal section, this person agreed with statements $1,3,5,6,8,2,11,12,16,17-20,28$, and strongly agreed with 


\section{FROM \\ TABLE \\ : RESULTS \\ CURRY COUNTY}

PART I: REFERRAL INFORMATION

$\underline{N}=1$

\begin{tabular}{|l|c|c|} 
& Number & $\begin{array}{l}\text { \% of } \\
\text { Total }\end{array}$ \\
\cline { 1 - 2 } $\begin{array}{l}\text { Total Possible } \\
\text { Referrals }\end{array}$ & 16 & 100 \\
\hline $\begin{array}{l}\text { Number Actually } \\
\text { Referred }\end{array}$ & 10 & 62 \\
\hline $\begin{array}{l}\text { Number Referred } \\
\text { to Louise Home }\end{array}$ & 4 & 25 \\
\hline $\begin{array}{l}\text { Number Accepted } \\
\text { at Louise Home }\end{array}$ & 4 & 25 \\
\hline
\end{tabular}

\begin{tabular}{l|c|c}
\multirow{2}{*}{ Villa St. Rose } & $\begin{array}{c}\text { Number } \\
\text { Listed }\end{array}$ & $\begin{array}{l}\text { \% of } \\
\text { Total }\end{array}$ \\
\cline { 2 - 3 } Farm Home & 1 & 100 \\
\hline Christy & 1 & 100 \\
\hline Youth Adventures & 1 & 100 \\
\hline Hillcrest & & \\
\hline White Shield & & \\
\hline Youth Care Center & & \\
\hline Chehalem House & 1 & 100 \\
\hline Boys \& Girls Alde & & \\
\hline Valadera & & \\
\hline No Response & & \\
\hline
\end{tabular}

Length of Stay in Position to Refer Girls

Average/Per. 60.00 Months

PART II:ATTITUDINAL SURVEY

MEANS

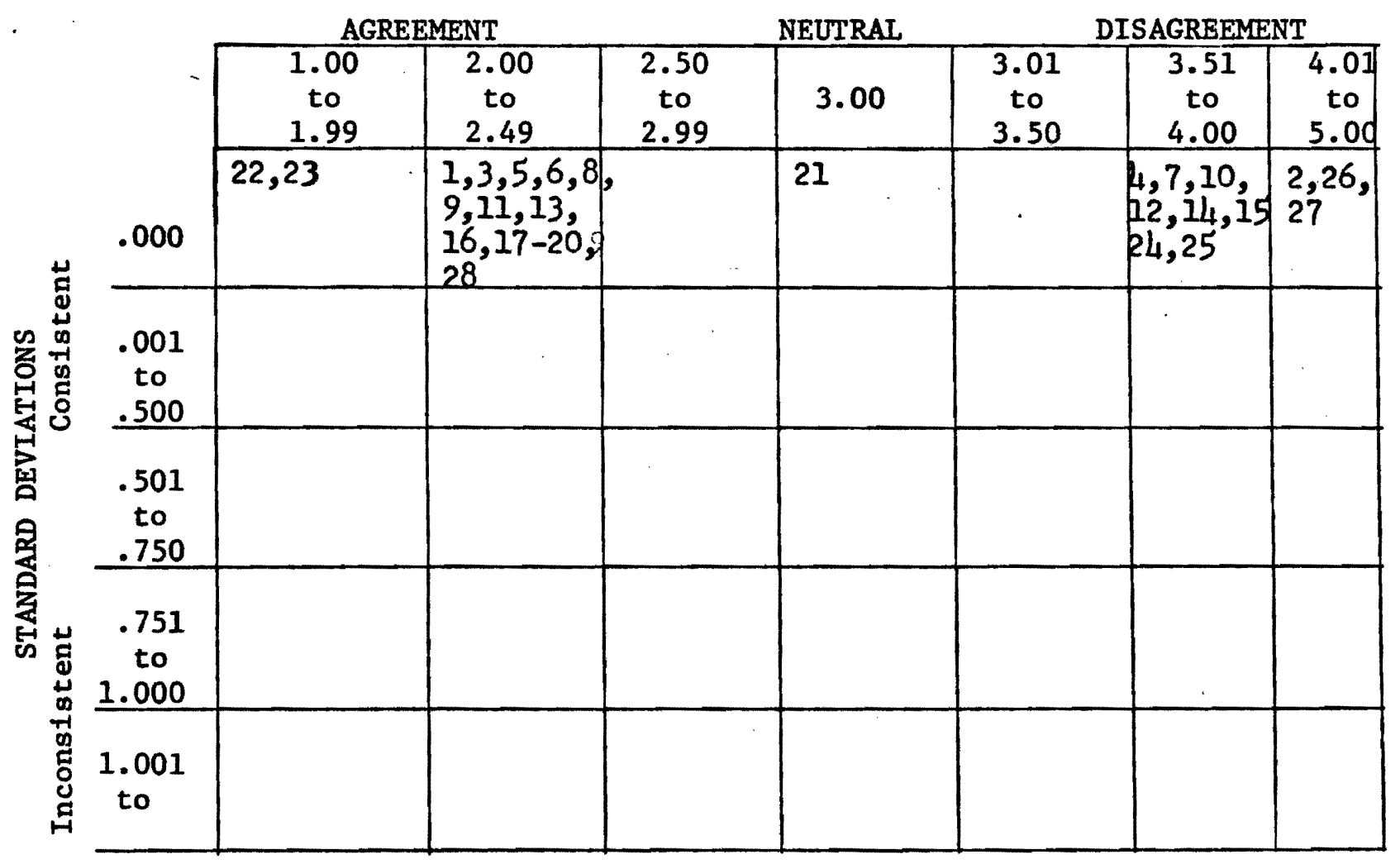


statements 22 and 23. In other words, he or she agreed 1) that organizational structure facilitates the Loulse Home's : operation; 2) that the Intake process is inconyenient; 3) that the caseworkers and child care workers are adequate and competent, respectively; 4) that the treatment philosophy is clear; 5) that the recreational program is an asset; 6) that the Louise Home provides an effective residential treatment program; 7) that the staff are in control; 8) that runaways are a problem; 9) that pre-placement visits are valuable; 10) that girls releases are we11 planned; 11) that there are more girls to refer in the school year than the summer; and strongly agreed that the school program was good, and that medical needs were sufficiently met: He or she disagreed with statements $4,7,10,12,14,15,24, .25$ and strongly disagreed with statements 2, 26 and 27. In other words, this person disagreed: 1) that the administration doesn't provide effective leadership; 2) that the physical factlities are below standard; 3) that the girls have too much freedom; 4) that home visits are not we11 planned; 5) that the recreation program is not a valuable part of treatment; 6) that it is vague what type of girl to refer to the Louise Home; 7) that the Louise Home is too far away to consider as a resource; and strongly disagreed: 1) that trying to communicate with the Louise Home is difficult; and 2) that there are adequate and more convenient resources for Louise Home type girls locally.

\section{Comments from Curry County}

"Biggest problem is the gas supply. Next is preplacement yisit. When a child can't stay oyernight (happened twice) I have to keep them in motel with: me and drag them along on all my other yisits. I usually prefer to stay two nights so I can visit more chtidren-which is more inconvenient." 
Deschutes County: (see Table $X$, page 42 ).

Considering the referral information first; it is noteworthy that the Deschutes sample referred $100 \%$ of theli eligible girls to the Louise Home; and got $100 \%$ of them accepted. In addition, they listed no other treatment center as a place of additional referrals; and were relatively new to their positions (nearly 30 months, below the ayerage of 34 months):

With reference to their attitudinal responses, they agreed tota1ly with statements $9,11,13,16,19,20$ and 23 ; or agreed 1) that the recreational program is an asset; 2) that visits by friends and relatives are usually a part of a girl's treatment program; 3) that the Louise Home provides an effective residential treatment program; 4) that the staff are in contro1; 5) that the release of girls from the Louise Home is well planned; and 6) that the school program is good. They disagreed totally with statements $2,3,4,7,10,12,14$ and 25 ; or disagreed: 1) that trying to communtcate with the Louise Home is difficult; 2) that the intake process is inconvenient; 3) that the Louise Home administration doesn't provide effective leadership; 42 that the physical facilities are below standard; 5) that the girls at the Loulse Home have too much freedom; 6) that home visits are not well planned and 7) that the Louise Home is too far away to consider as a resource. They also consistently strongly disagreed with statements 26 and 27 , that there are adequate and more conyenient resources than the Louise Home locally, A11 in all, it appears that the sample's opinions are generally fayorable to the Loulse Home as they tended almost totally to agree with positiye 
TABLE $\triangle$ : RESULTS

FROM DESCHUTES COUNTY

PART I: REFERRAL INFORMATION

$\underline{N}=2$

\begin{tabular}{|l|c|c} 
& Number & $\begin{array}{l}\text { \% of } \\
\text { Total }\end{array}$ \\
\hline $\begin{array}{l}\text { Total Possible } \\
\text { Referrals }\end{array}$ & 6 & 100 \\
\hline $\begin{array}{l}\text { Number Actually } \\
\text { Referred }\end{array}$ & 3 & 50 \\
\hline $\begin{array}{l}\text { Number Referred } \\
\text { to Louise Home }\end{array}$ & 3 & 50 \\
\hline $\begin{array}{l}\text { Number Accepted } \\
\text { at Louise Home }\end{array}$ & 3 & 50 \\
\hline
\end{tabular}

\begin{tabular}{l|l|l} 
& $\begin{array}{l}\text { Number } \\
\text { Listed }\end{array}$ & $\begin{array}{l}\% \text { of } \\
\text { Total }\end{array}$ \\
\cline { 2 - 3 } Villa St. Rose & & \\
\hline Farm Home & & \\
\hline Christy & & \\
\hline Youth Adventures & & \\
\hline Hillcrest & & \\
\hline White Shield & & \\
\hline Youth Care Center & & \\
\hline Chehalem House & & \\
\hline Boys \& Girls Aide & & \\
\hline Valadera & & \\
\hline Other & & \\
\hline No Response & 2 & 100 \\
\hline
\end{tabular}

Length of Stay in Position to Refer Girls

Average/Per.

5.50 Months

PART II:ATTITUDINAL SURVEY

MEANS

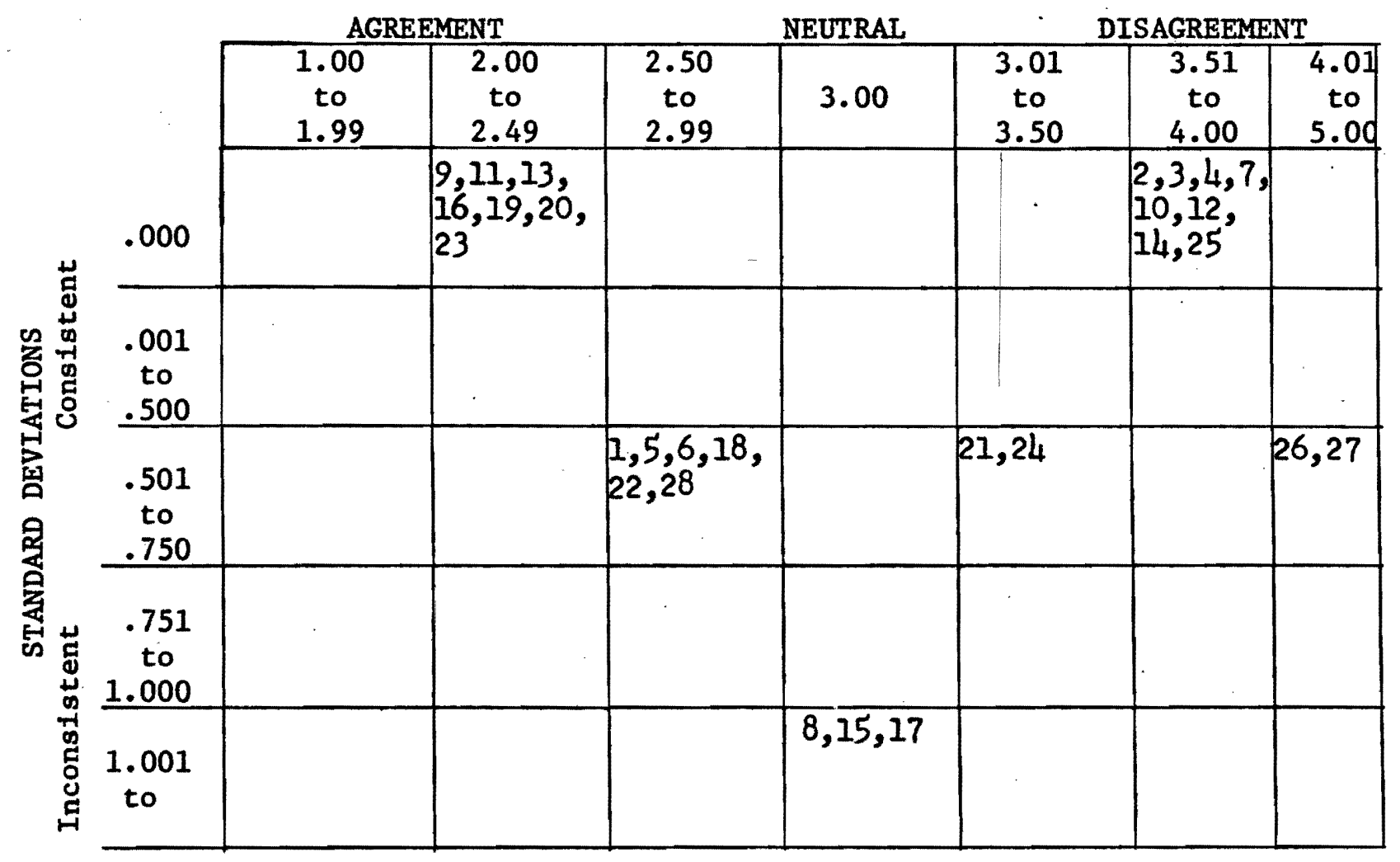


statements about it; : and disagree with negative : statements :

\section{Comments from Deschutes County}

"I: have not made referrals/placements: to Loulse for two years due to change in jobs:" :

"Much information I don't know - is that 'neutral?"!

\section{Douglas County (see Table XI, page 44):}

From the referral information, it Is evident that the Louise Home was sent $100 \%$ of Douglas County's actual referrals, and accepted nearly three-quarters of them. : Twenty percent of the sample also listed Villa St. Rose as an additional place of referral, but importantly $80 \%$ listed no other residential center. It is also notable that the average length of time spent in a position to refer was a little over one year greater than for the total sample. Attitudinally, the sample tended to consistently respond neutrally to the majority of the statements, only slightly agreeing or disagreeing. With some statements there was a large dispairty In responses $(19,25,57$, and 26). It seemed then that there was some disagreement of whether the Louise Home is too far away to consider as a resource: of whether more convenient and adequate resources existed locally; or of whether pre-placement visits were valuable. There was consistent disagreement with statement 7 , that the physical facilities at the Louise Home are below standard. There was also disagreement with statement 8 , but less consistently. In other words, there was disagreement that the Louise Home treatment philosophy is clear. All in all, it seems that Douglas County may lack some basic knowledge of the Louise Home." Notably though 


FROM ${ }^{\text {TABLE }} \frac{X I}{\text { DOUGLAS }}: \begin{array}{r}\text { RESULTS } \\ \text { COUNTY }\end{array}$

PART I: REFERRAL INFORMATION

\begin{tabular}{|l|c|c} 
& Number & $\begin{array}{l}\% \text { of } \\
\text { Total }\end{array}$ \\
\hline $\begin{array}{l}\text { Total Possible } \\
\text { Referrals }\end{array}$ & 16 & 100 \\
\hline $\begin{array}{l}\text { Number Actually } \\
\text { Referred }\end{array}$ & 7 & 44 \\
\hline $\begin{array}{l}\text { Number Referred } \\
\text { to Louise Home }\end{array}$ & 7 & 44 \\
\hline $\begin{array}{l}\text { Number Accepted } \\
\text { at Louise Home }\end{array}$ & 5 & 31 \\
\hline
\end{tabular}

Length of Stay Average/Per. In Position to 16.20 Months
Refer Girls

$$
\underline{N}=\underline{10}
$$

\begin{tabular}{l|c|c} 
& $\begin{array}{l}\text { Number } \\
\text { Listed }\end{array}$ & $\begin{array}{l}\% \text { of } \\
\text { Total }\end{array}$ \\
\cline { 2 - 3 } Vi1la St. Rose & 2 & 20 \\
\hline Parm Home & & \\
\hline Christy & & \\
\hline Youth Adventures & & \\
\hline Hillcrest & & \\
\hline White Shield & & \\
\hline Youth Care Center & & \\
\hline Chehalem House & & \\
\hline Boys \& Girls Aide & & \\
\hline Valadera & & \\
\hline Other & & \\
\hline No Response & 8 & 80 \\
\hline
\end{tabular}

\section{PART II:ATTITUDINAL SURVEY}

\section{MEANS}

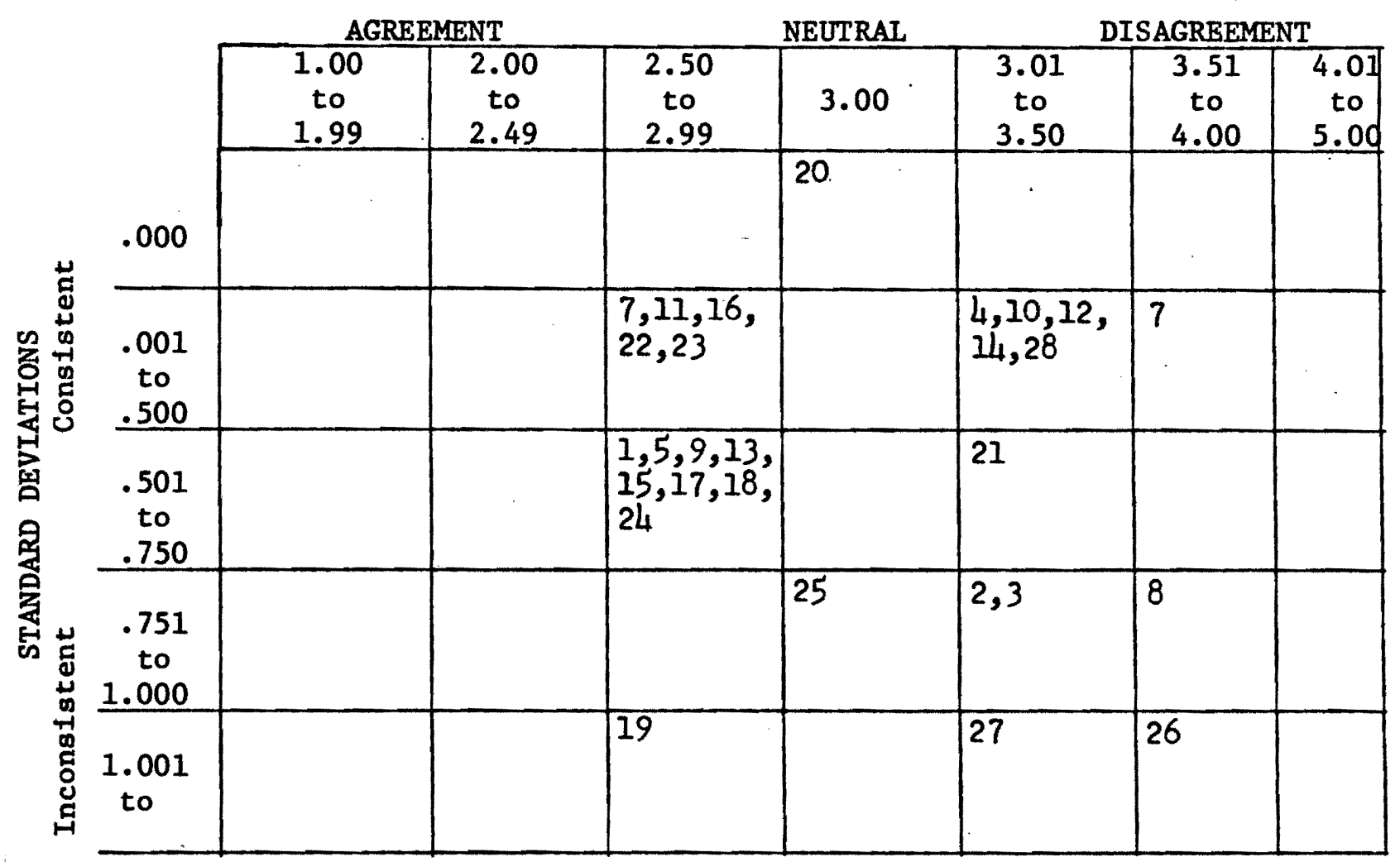


It doesn't appear to effect their referral rate:

Comments from Douglas County

"We: are discouraged within our own county to make referrals to Louise Home:"

"I.would 1ike to know more about this school's program."

"A11 answers are neutral because of no contact with

Louise Home. I do feel it is better to resolve a problem

In the communty, if possible:"

Harney-Malheur Counties (see Table XII, page 46)

In looking at the referral data received from Harney and Malheur counties, there are three significant factors: 1) the only girl they referred to a residential setting was to the Louise Home; 2) the average length of stay of a caseworker was 10 months over the ayerage of the total sample; and 3) none of the four people responding to the questionnaire listed any other residential treatment centers.

In the attitudinal data, we find that all four workers answered, the same; that they were in total agreement with each other. on questions $1,4-7,9-12,14,16,18-25$, and 28 they answered neutra1. They agreed with questions 15 and 17 ; or that: 1 ) it is vague what type of gir1 should be referred to the Louise Home; and 2) that runaways are a problem at the Louise Home. They were in disagreement with questions $2,3,8,13,26,27$; or disagreed that: 1) trying to communicate with the Louise Home is difficult; 2) the intake procedure is inconvenient; 3) that the treatment philosophy is clear; 4) that the Louise Home proyides an effective residential treatment program; and 5) that they haye adequate and more conyenient resources within their own commity.

Comments from Harney-Malheur Counties

"I have had no contact with Louise Home at a11." 
TABLE XII : RESULTS

FROM HARNEY-MALHEUR COUNTY

PART I: REFERRAL INFORMATION

$\underline{N}=4$

\begin{tabular}{|l|c|c|} 
& Number & $\begin{array}{l}\text { z of } \\
\text { Total }\end{array}$ \\
\hline $\begin{array}{l}\text { Total Possible } \\
\text { Referrals }\end{array}$ & 3 & 100 \\
\hline $\begin{array}{l}\text { Number Actually } \\
\text { Referred }\end{array}$ & 1 & 33 \\
\hline $\begin{array}{l}\text { Number Referred } \\
\text { to Louise Home }\end{array}$ & 1 & 33 \\
\hline $\begin{array}{l}\text { Number Accepted } \\
\text { at Louise Home }\end{array}$ & 1 & 33 \\
\hline
\end{tabular}

\begin{tabular}{l|l|l} 
& $\begin{array}{l}\text { Number } \\
\text { Listed }\end{array}$ & $\begin{array}{l}\text { \% of } \\
\text { Total }\end{array}$ \\
\cline { 2 - 3 } Villa St. Rose & & \\
\hline Farm Home & & \\
\hline Christy & & \\
\hline Youth Adventures & & \\
\hline Hillcrest & & \\
\hline White Shield & & \\
\hline Youth Care Center & & \\
\hline Chehalem House & & \\
\hline Boys \& Girls Aide & & \\
\hline Valadera & & \\
\hline Other & & \\
\hline No Response & 4 & 100 \\
\hline
\end{tabular}

Length of Stay Average/Per.

in Position to
Refer Girls $\quad 44.25$ Months

PART II:ATTITUDINAL SURVEY

MEANS

\begin{tabular}{|c|c|c|c|c|c|c|c|}
\hline & & MENT & & NEUTRAL & & SAGREEN & \\
\hline & $\begin{array}{c}1.00 \\
\text { to } \\
1.99 \\
\end{array}$ & $\begin{array}{c}2.00 \\
\text { to } \\
2.49 \\
\end{array}$ & $\begin{array}{c}2.50 \\
\text { to } \\
2.99 \\
\end{array}$ & 3.00 & $\begin{array}{c}3.01 \\
\text { to } \\
3.50 \\
\end{array}$ & $\begin{array}{c}3.51 \\
\text { to } \\
4.00 \\
\end{array}$ & $\begin{array}{r}4.01 \\
\text { to } \\
5.00 \\
\end{array}$ \\
\hline .000 & & $\pm 5,17$ & & $\begin{array}{l}1,4-7,9, \\
10-12,14, \\
16,18-25, \\
28\end{array}$ & 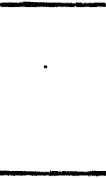 & $\begin{array}{l}2,3,8, \\
13,26, \\
27\end{array}$ & \\
\hline 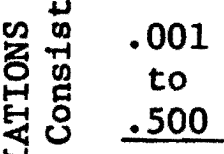 & & & & & & & \\
\hline $\begin{array}{ll}.501 \\
\text { to } \\
.750 \\
\end{array}$ & & & & & & & \\
\hline 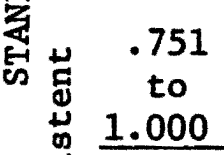 & & & & & $\therefore$ & & \\
\hline 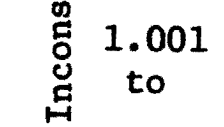 & & & & & & & \\
\hline
\end{tabular}


Jefferson County: (see Table XIII, page 48)

In examining the referral information from Jefferson county, there are four significant facts: 1) $17 \%$ of the girls actually referred to residential centers were referred to the Louise Home; 2) the only gir1 referred to the Louise Home was not accepted; 3) the average length of stay of the workers polled in this county was 20 months below the average of the total sample; and 4) that $67 \%$ of the workers who responded to this questionnaire listed Vi11a St. Rose and Youth Adventures, both of which are in the greater Portland area, as other places they refer girls.

Considering the attitudinal data, there was total agreement on question 28, and fairly consistent agreement on questions 15 and 19. They all agreed that there are more girls to refer to the Louise Home during the school year. . They fairly consistently agreed that: 1) It Is vague what type of girl should be referred to the Louise Home; and 2) pre-placement visits to the Louise Home are yaluable. There was total disagreement by all caseworkers on questions 25,26 , and 27 and less consistent disagreement with question 8 . They unanimously disagreed that: 1) the Loulse Home is too far away to consider as a resource; and 2) there are adequate and more convenient resources within their own commity. There was less consistent disagreement that the Loulse Home treatment philosophy is clear.

A11 the workers in Jefferson County responded neutrally : to questions $1,2,4,5,6,7,9,10,13,14 ; 16,17,18$ and $20-24$.

\section{Comments from Jefferson County}

"Hayen't yet had the' time to check into the Louise Home program. 'Hayen't had any girls needing to be referred." 
TABLE XIII : RESULTS

FROM JEFFERSON COUNTY

PART I: REFERRAL INFORMATION

\begin{tabular}{|l|c|c} 
& Number & $\begin{array}{l}\% \text { of } \\
\text { Total }\end{array}$ \\
\hline $\begin{array}{l}\text { Total Possible } \\
\text { Referrals }\end{array}$ & 9 & 100 \\
\hline $\begin{array}{l}\text { Number Actually } \\
\text { Referred }\end{array}$ & 6 & 67 \\
\hline $\begin{array}{l}\text { Number Referred } \\
\text { to Louise Home }\end{array}$ & 1 & 11 \\
\hline $\begin{array}{l}\text { Number Accepted } \\
\text { at Louise Home }\end{array}$ & 0 & 0 \\
\hline
\end{tabular}

Length of Stay Average/Per. in Position to Refer Girls
$\underline{N}=3$

\begin{tabular}{l|c|c} 
& $\begin{array}{l}\text { Number } \\
\text { Listed }\end{array}$ & $\begin{array}{l}\% \text { of } \\
\text { Total }\end{array}$ \\
\cline { 2 - 3 } Villa St. Rose & 2 & 67 \\
\hline Farm Home & & \\
\hline Christy & & \\
\hline Youth Adventures & 2 & 67 \\
\hline Hillcrest & & \\
\hline White Shield & & \\
\hline Youth Care Center & & \\
\hline Chehalem House & & \\
\hline Boys \& Girls Aide & & \\
\hline Valadera & & \\
\hline Other & 1 & 33 \\
\hline No Response & 1 & 33 \\
\hline
\end{tabular}

PART II:ATTITUDINAL SURVEY

MEANS

\begin{tabular}{|c|c|c|c|c|c|c|c|}
\hline \multirow[b]{3}{*}{.000} & \multicolumn{2}{|c|}{ AGREEMENT } & & \multicolumn{2}{|l|}{ NEUTRAL } & \multicolumn{2}{|c|}{ DISAGREEMENT } \\
\hline & $\begin{array}{r}1.00 \\
\text { to } \\
1.99 \\
\end{array}$ & $\begin{array}{c}2.00 \\
\text { to } \\
2.49 \\
\end{array}$ & $\begin{array}{c}2.50 \\
\text { to } \\
2.99 \\
\end{array}$ & 3.00 & $\begin{array}{l}3.01 \\
\text { to } \\
3.50 \\
\end{array}$ & \begin{tabular}{|c|}
3.51 \\
to \\
4.00 \\
\end{tabular} & $\begin{array}{r}4.01 \\
\text { to } \\
5.00 \\
\end{array}$ \\
\hline & & 28 & -. & $\begin{array}{l}1,4-7,9,10 \\
13,14,16, \\
17,18,20- \\
24\end{array}$ & & $\begin{array}{l}25,26, \\
27\end{array}$ & \\
\hline 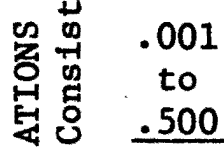 & & & & & & & \\
\hline $\begin{array}{ll}\text { 回 } & .501 \\
\text { 量 } & \text { to } \\
& .750 \\
\end{array}$ & & 15,19 & $3,11,12$ & & & 8 & \\
\hline 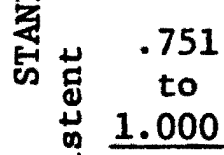 & & & & & & & \\
\hline $\begin{array}{cc}\stackrel{0}{Z} & 1.001 \\
\stackrel{\Xi}{\Xi} & \text { to }\end{array}$ & & & & & & & \\
\hline
\end{tabular}




\footnotetext{
"Know nothing about the Louise Home; its program, or staff."

"Answers are based on lack of personal knowledge or experience with Louise Home: My caseload consists of Indian families: I was told that Louise Home is refusing to consider placement of Indian girls due to poor history of success with them."
}

Josephire and Jackson Counties: (see Table XIV, page 50)

Josephine and Jackson counties referred $65 \%$ of their possible referrals to residential treatment centers; with Louise Home getting $20 \%$ of those referrals. We find that girls were referred to seven other residential centers; Villa St. Rose being listed by more of the workers than any other ( $37 \%$ of the respondents).

Examining the attitudinal data we find fairly consistent agreement with questions 11,19 and 23 ; and less consistent agreement with questions 12 and 17. They are In agreement consistently: 1) that visits by friends and relatives are part of a girl's treatment program at the Louise Home; 2) that pre-placement visits are valuable; and 3) that the school program at the Louise Home is good. They were In less consistent agreement: 1) that home visits are not we11 planned; and 2) that runaways are a problem at the Loulse Home. There was fairly consistent disagreement with questions 10,14 and 24; and less consistent disagreement with questions $2,7,21$ and 26 . They were in disagreement: 1) that girls have too much freedom at the Louise Home; 2) that the recreational program is not a yaluable part of treatment at the Louise Home, and 3) that the Louise Home places too great an emphasis on religion. They less conststently disagreed: 1) that trying to cominicate with the Louise Home is 
TABLE XIV : RESULTS

FROM JOSEPHINE-JACKSON COUNTY

PART I: REFERRAL INFORMATION

\begin{tabular}{|l|c|c} 
& Number & $\begin{array}{l}\% \text { of } \\
\text { Total }\end{array}$ \\
\cline { 1 - 2 } $\begin{array}{l}\text { Total Possible } \\
\text { Referrals }\end{array}$ & 23 & 100 \\
\hline $\begin{array}{l}\text { Number Actually } \\
\text { Referred }\end{array}$ & 15 & 65 \\
\hline $\begin{array}{l}\text { Number Referred } \\
\text { to Louise Home }\end{array}$ & 3 & 13 \\
\hline $\begin{array}{l}\text { Number Accepted } \\
\text { at Louise Home }\end{array}$ & 2 & 9 \\
\hline
\end{tabular}

Length of Stay in Position to Refer Girls

$\frac{\text { Average/Per. }}{27.88 \text { MONTHS }}$

$\underline{N}=9$

\begin{tabular}{l|c|c} 
& $\begin{array}{l}\text { Number } \\
\text { Listed }\end{array}$ & $\begin{array}{l}\% \text { of } \\
\text { Total }\end{array}$ \\
\cline { 2 - 3 } Vi1la St. Rose & 3 & 33 \\
\hline Farm Home & & \\
\hline Christy & 1 & 11 \\
\hline Youth Adventures & 1 & 11 \\
\hline Hillcrest & 1 & 11 \\
\hline White Shield & 1 & 11 \\
\hline Youth Care Center & & \\
\hline Chehalem House & 1 & 11 \\
\hline Boys \& Girls Aide & & \\
\hline Valadera & & \\
\hline Other & 2 & 22 \\
\hline No Response & 4 & 44 \\
\hline
\end{tabular}

PART II:ATTITUDINAL SURVEY

MEANS

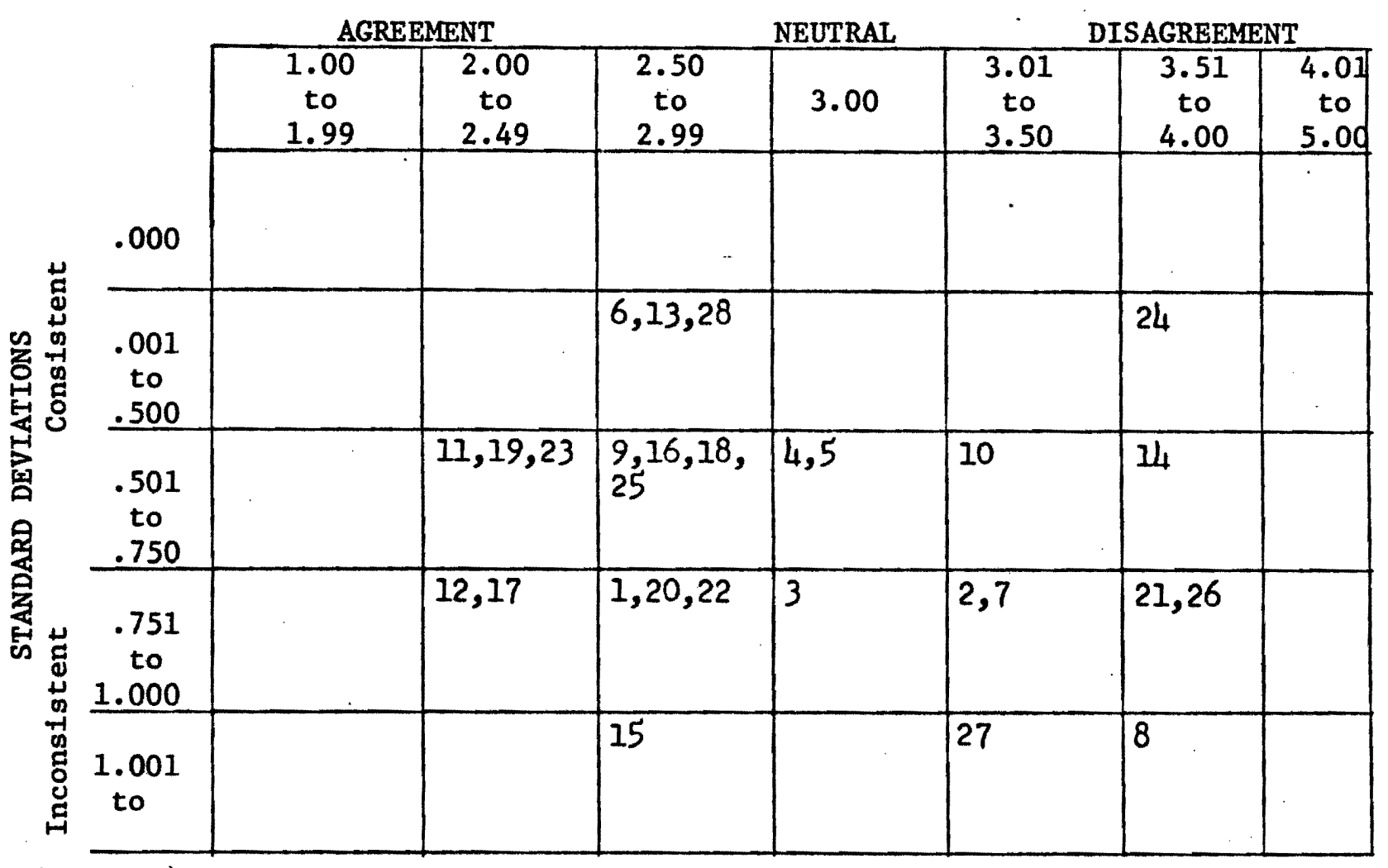


difficult; $: 2)$ that the physical facilities are below standard;

3) that there is good follow-up after girls are released; and 4) that there are adequate resources within their own commities:

\section{Comments from Josephine-Jackson Counties}

"Don't : know anything about Louise Home."

"I have had no contact with Louise Home for two or three years. No girls in my caseload are currently in any type of institutional care. Neutral answers indicate lack of first-hand information or experience with present program at Louise Home." Distance problems oyer home visits were, and still are serious drawbacks."

"I do not know enough about Louise Home to fill out the rest of this form to any degree of reliability."

"Most of the questions could not be adequately answered by the five choices and I feel the questionnaire results may be misleading. I feel that Louise Home does meet the needs of some girls very well, but of ten the wrong type is referred and accepted. We do have more community resources for these girls now, but not enough."

Klamath-Lake Counties (see Table XV, page 52)

Looking at the referral information, it is apparent in the sample from Klamath-Lake Counties that the Louise Home recelyed $52 \%$ of the actual number of girls referred to residential treatment centers; and accepted $62 \%$ of those referred.

In the attitudinal data there is both consistency and differences of opinions towards some statements, as well as strong agreement and disagreement with others. There was total agreement with statements 1, 6 and 16; or agreement: 1) that the organizational structure facilitates the Louise Home's operation; 22 that the child care workers are competent; and 3) that the staff are in control of the Louise Home: There was fairly consistent strong agreement with statements 5 and 13; or strong agreement: 1) that caseworkers do an 
TABLE XV : RESULTS

FROM KIAMATH-IAKE COUNTY

PART I: REFERRAL INFORMATION

$$
\underline{N}=\underline{5}
$$

\begin{tabular}{|l|c|c} 
& Number & $\begin{array}{l}\% \text { of } \\
\text { Total }\end{array}$ \\
\hline $\begin{array}{l}\text { Total Possible } \\
\text { Referrals }\end{array}$ & 43 & 100 \\
\hline $\begin{array}{l}\text { Number Actually } \\
\text { Referred }\end{array}$ & 21 & 48 \\
\hline $\begin{array}{l}\text { Number Referred } \\
\text { to Louise Home }\end{array}$ & 11 & 25 \\
\hline $\begin{array}{l}\text { Number Accepted } \\
\text { at Louise Home }\end{array}$ & 7 & 16 \\
\hline
\end{tabular}

\begin{tabular}{l|c|c} 
& $\begin{array}{l}\text { Number } \\
\text { Listed }\end{array}$ & $\begin{array}{l}\% \text { of } \\
\text { Total }\end{array}$ \\
\cline { 2 - 3 } Villa St. Rose & 2 & 40 \\
\hline Farm Home & 1 & 20 \\
\hline Christy & & \\
\hline Youth Adventures & & \\
\hline Hillcrest & 1 & 20 \\
\hline White Shield & 1 & 20 \\
\hline Youth Care Center & & \\
\hline Chehalem House & & \\
\hline Boys \& Girls Aide & & \\
\hline Valadera & & \\
\hline Other & & \\
\hline No Response & 2 & 40 \\
\hline
\end{tabular}

Length of Stay Average/Per. in Position to Refer Girls 29.00 Months

PART II: ATTITUDINAL SURVEY

MEANS

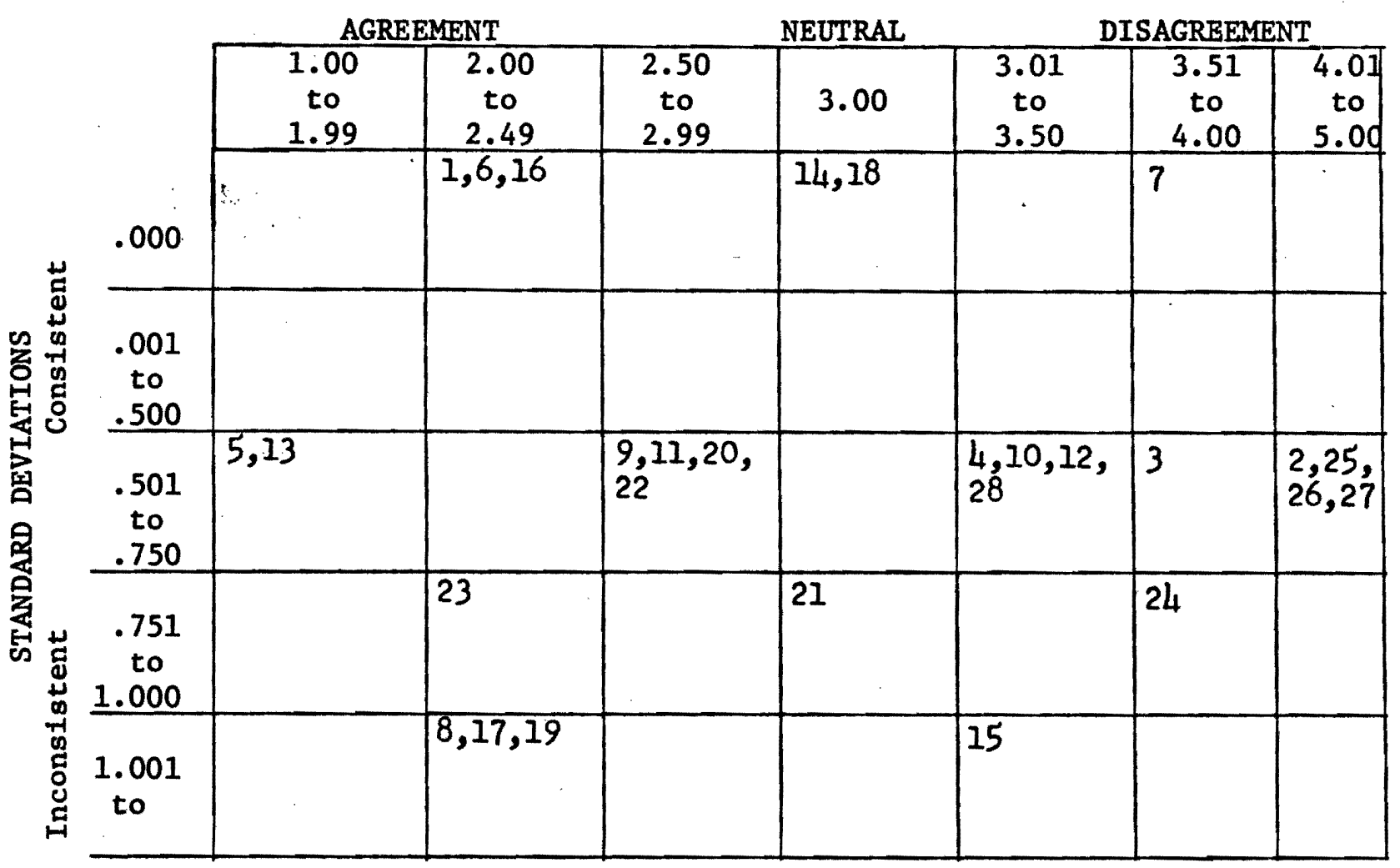


adequate job; and 2 ) that the Louise Home provides an effective residential treatment program. : There was consistent disagreement with statement 3 , that the intake process at the Louise Home Is Inconvenient; and total disagreement with statement 7 , that the physical facilities are below standard. There was also consistently strong disagreement with statements $2,25-27$; or strong disagreement: 1) that trying to communicate with the Loilse Home is difficult; 2) that the Louise Home is too far away to consider as a resource; and 3) that there are adequate and more conyentent resources for teenage girls 1ocally.

\section{Comments from Klamath-Lake Counties}

"I do not have on-going contact wh the institution to answer most of these questions on the basts of first-hand experiences: Neutral is used when 'don't know would be a more appropriate response:"

"I am unfamiliar with Louise Home program and facilities. My information is limited to contacts with institutional liaison personnel of C.S.D. In one case with which I am familiar the Louise Home caseworker eyidently made a trusting relationship with the girl and she was not reluctant to return following runaways."

"Excellent communication and joint planning between Louise Home and our C.S.D. people."

"I have not recently referred any girls to Louise Home, but have worked in the past with girls released from Louise Home: My last direct contact with children released from your facility: was about 15 months ago."

Lane County (see Table XVI, page 54)

The most glaring fact in the referral information for Lane County is that they referred only $11 \%$ of their actual referrals to the Louise Home; and that only three-fifths of these were accepted. In addition, $62 \%$ and $50 \%$ of the sample listed Villa St. Rose and 
FROM $\frac{\text { TABLE } \frac{\text { TII }}{\text { IANE }}: \text { RESULTS }}{\text { CONE }}$

COUNTY

PART I: REFERRAL INFORMATION

$\underline{N}=8$

\begin{tabular}{|l|c|c} 
& Number & $\begin{array}{l}\% \text { of } \\
\text { Total }\end{array}$ \\
\hline $\begin{array}{l}\text { Total Possible } \\
\text { Referrals }\end{array}$ & 48 & 100 \\
\hline $\begin{array}{l}\text { Number Actually } \\
\text { Referred }\end{array}$ & 43 & 89 \\
\hline $\begin{array}{l}\text { Number Referred } \\
\text { to Louise Home }\end{array}$ & 5 & 10 \\
\hline $\begin{array}{l}\text { Number Accepted } \\
\text { at Louise Home }\end{array}$ & 3 & 6 \\
\hline
\end{tabular}

\begin{tabular}{l|c|c} 
& Number & $\begin{array}{c}\% \text { of } \\
\text { Total }\end{array}$ \\
\cline { 2 - 3 } Vistla St. Rose & 5 & 62 \\
\hline Farm Home & 2 & 25 \\
\hline Christy & 2 & 25 \\
\hline Youth Adventures & & \\
\hline Hillcrest & & \\
\hline White Shie1d & & \\
\hline Youth Care Center & 4 & 50 \\
\hline Chehalem House & 1 & 13 \\
\hline Boys \& Girls Aide & & \\
\hline Valadera & 1 & 13 \\
\hline Other & & \\
\hline No Response & 1 & 13 \\
\hline
\end{tabular}

Length of Stay in Position to Refer Girls

Average/Per.

96.00 Months

PART II: ATTITUDINALSURVEY

MEANS

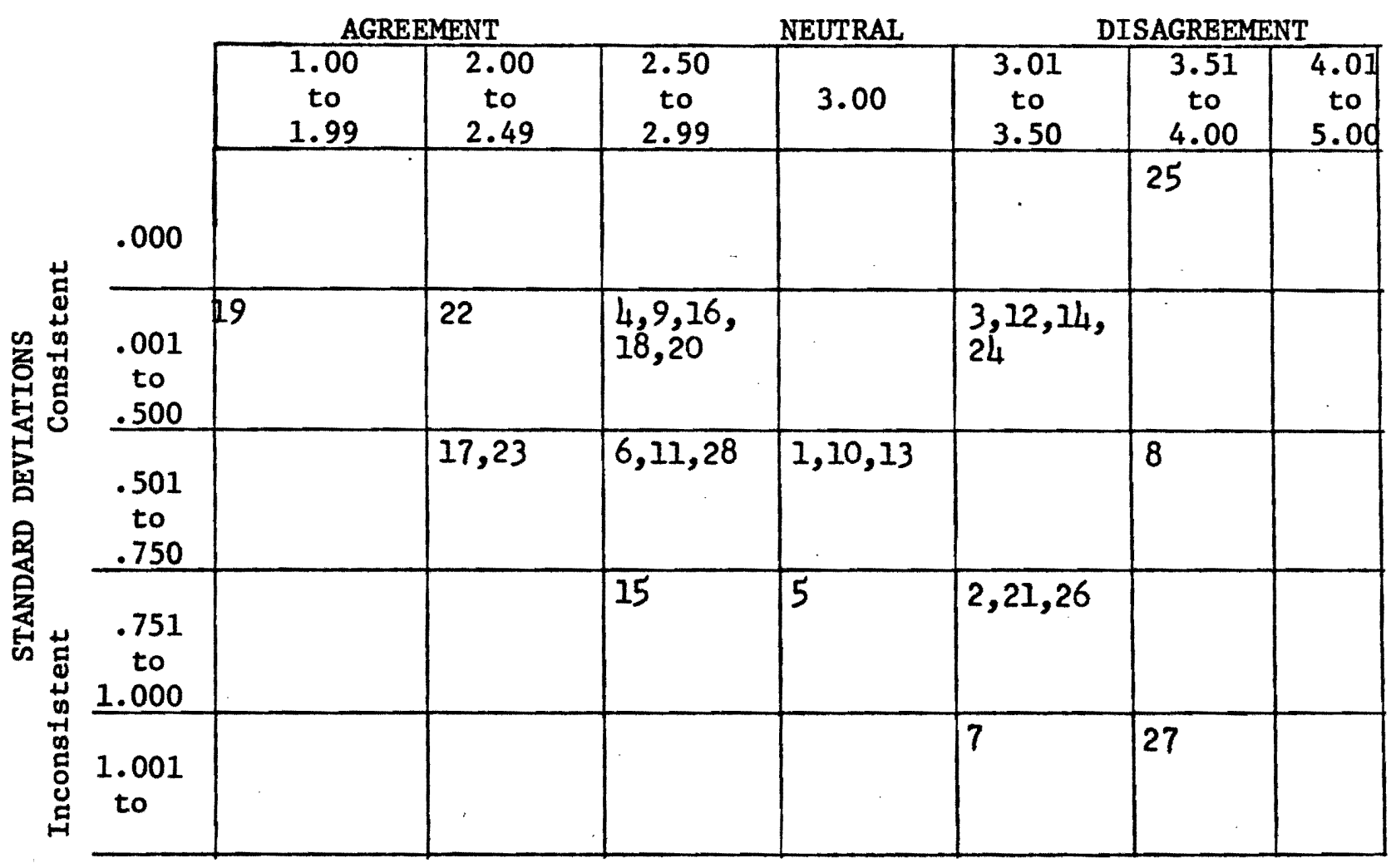


Youth Care Centers, respectively, as alternative referral sites. It is notable too, that the average length of time in positions of referral is three times the norm for the total sample (noting that the range was 0 to 340 months):

The attitudinal data on Iane County indicates that the majority of the responses tended to be neutral with slight degrees of agreement and disagreement. There was consistent agreement with statements 22,17 and 23 ; and strong agreement with statement 19 ; or agreement: 1) that the medical needs of the girls are met; 2) that runaways are a problem; 3) that the school program is good; and strong agreement that pre-placement visits are valuable. There was consistent disagreement with statements 25,8 and less consistently with statement 27 ; or disagreement: 1) that the Louise Home is too far away; 2) that the treatment philosophy is clear; and 3) that there are more adequate resources locally for girls eligible for the Louise Home.

\section{Comments from Lane County}

"The reason for ail the neutral responses Is because I don' $t$ know that much about Louise Home. I suggest to caseworkers that they check out Louise Home as a possible resource."

"I have had no contact with Loulse Home in over three years."

"In many instances I do not know and have nothing to hang a decision on and haye therefore not answered."

"My last contact with Louise, one ending in 1972, was quite satisfactory. I just hayen't had a girl in need of this type of care since then." 
Marion County (see Table XVII, page 57)

Referral information from Marion County indicates the following: 1) Out of the total possible referrals on1y $56 \%$ were actually referred to residential treatment centers; 2 ) that $19 \%$ of the total possible referrals got referred to the Louise Home, or about $33 \%$ of those who are actually referred; 3) of the four respondents three, or $75 \%$ of them listed Villa St. Rose and Farm Home, as other centers referred to. Christy, Chehalem House and Boys and Girls Aid were other centers listed by $50 \%$ of the respondents; 4) the average length of stay of a worker was over 24 months longer than the average of the total sample.

The attitudinal data indicated fairly consistent strong agreement on questions 15 and 17 ; the correspondents tended to strongly agree that: 1) it was vague what type of gir1 to refer to the Louise Home; and 2) runaways are a problem at the Louise Home. The respondents fairly consistently agreed with questions $10,11,22,28$; and less consistently agreed with question 19. They agreed that: 1) Girls have too much freedom at the Louise Home; 2) visits by friends and relatives are usually part of a girl's treatment program; 3) the medical needs of girls are met sufficiently; 4) there are more girls to refer during the school year. They less consistently agreed that: 1) pre-placement visits to the Louise Home are valuable. There was fairly consistent strong disagreement with question 8 ; or that the Louise Home treatment philosophy is clear. All workers disagreed with questions 26 and 27 ; that there were adequate and more convenient resources within their own communities. There was fairly consistent disagreement with questions 
TABLE XVII : RESULTS FROM MARION COUNTY

PART I: REFERRAL INFORMATION

$$
\underline{N}=4
$$

\begin{tabular}{|l|c|c} 
& Number & $\begin{array}{l}\text { \% of } \\
\text { Total }\end{array}$ \\
\hline $\begin{array}{l}\text { Total Possible } \\
\text { Referrals }\end{array}$ & 63 & 100 \\
\hline $\begin{array}{l}\text { Number Actual1y } \\
\text { Referred }\end{array}$ & 35 & 56 \\
\hline $\begin{array}{l}\text { Number Referred } \\
\text { to Louise Home }\end{array}$ & 12 & 19 \\
\hline $\begin{array}{l}\text { Number Accepted } \\
\text { at Louise Home }\end{array}$ & 8 & 13 \\
\hline
\end{tabular}

\begin{tabular}{l|c|c} 
& Number & $\begin{array}{c}\% \text { of } \\
\text { Total }\end{array}$ \\
\cline { 2 - 3 } Villa St. Rose & 3 & 75 \\
\hline Farm Home & 3 & 75 \\
\hline Christy & 2 & 50 \\
\hline Youth Adventures & 1 & 25 \\
\hline Hillcrest & & \\
\hline White Shield & & \\
\hline Youth Care Center & & \\
\hline Chehalem House & 2 & 50 \\
\hline Boys \& Girls Aide & 2 & 50 \\
\hline Valadera & & \\
\hline Other & 3 & 75 \\
\hline No Response & 1 & 25 \\
\hline
\end{tabular}

Length of Stay in Position to Refer Girls

Average/Per. 60.25 MONTHS 
21. and 24, and less consistent disagreement with question 13 ; they disagreed that 1) there was good follow-up after girls were released;

2) the Louise Home places too great an emphasis on religion; with less consistent disagreement that Louise Home provides an effective residential treatment program.

A11 the respondents answered neutrally to question 18; that Louise Home provides a sound nutritional diet:

\section{Comments from Marion County}

"The Loulse Home program is unclear and our use of this facility seems to be on the decline. A recent poll in our office (regarding the five girls) indicated, in all cases, that none of the placements could be considered a success."

Multnomah County - East (see Table XVIII, page 59)

In looking at the referral data from East Multnomah County Children's.Services Division, we find the following significant data: 1) only $56 \%$ of the total possible referrals are actually referred to residential treatment centers; 2) Louise Home gets approximately $50 \%$ of those actually referred; 3) the average length of stay of the workers who responded is approximately one year below the average of the total sample; and 4) that $63 \%$ of those polled did not respond by writing other centers they referred girls to.

Attitudinally, the workers had fairly consistent strong agreement with questions 19 and 23; they strongly agreed that pre-placement visits to the Louise Home are valuable; and that the school program at the Louise Home is good. They had fairly consistent agreement on questions $5,11,22$; and less consistent agreement on question 17. They agreed that: 1) caseworkers do an adequate job; 2) visits of friends and relatives are part of a girl's treatment program; 3) medical needs are met sufficiently; and less consistently agreed 
TABLE XVIII : RESULTS

FROM MULTNOMAH (EAST) COUNTY

PART I: REFERRAL INFORMATION

$\underline{N}=16$

\begin{tabular}{|l|c|c} 
& Number & $\begin{array}{l}\text { \% of } \\
\text { Total }\end{array}$ \\
\hline $\begin{array}{l}\text { Total Possible } \\
\text { Referrals }\end{array}$ & 55 & 100 \\
\hline $\begin{array}{l}\text { Number Actually } \\
\text { Referred }\end{array}$ & 31 & 56 \\
\hline $\begin{array}{l}\text { Number Referred } \\
\text { to Louise Home }\end{array}$ & 16 & 29 \\
\hline $\begin{array}{l}\text { Number Accepted } \\
\text { at Louise Home }\end{array}$ & 11 & 20 \\
\hline
\end{tabular}

\begin{tabular}{l|c|c} 
& $\begin{array}{l}\text { Number } \\
\text { Listed }\end{array}$ & $\begin{array}{l}\% \text { of } \\
\text { Total }\end{array}$ \\
\cline { 2 - 3 } Villa St. Rose & 4 & 25 \\
\hline Farm Home & 1 & 6 \\
\hline Christy & 2 & 13 \\
\hline Youth Adventures & 2 & 13 \\
\hline Hillcrest & & \\
\hline White Shield & & \\
\hline Youth Care Center & & \\
\hline Chehalem House & & \\
\hline Boys \& Girls Aide & & \\
\hline Valadera & & \\
\hline Other & 2 & 13 \\
\hline No Response & 10 & 63 \\
\hline
\end{tabular}

Length of Stay Average/Per. 23 Months

PART II ATTITUDINAL SURVEY

MEANS

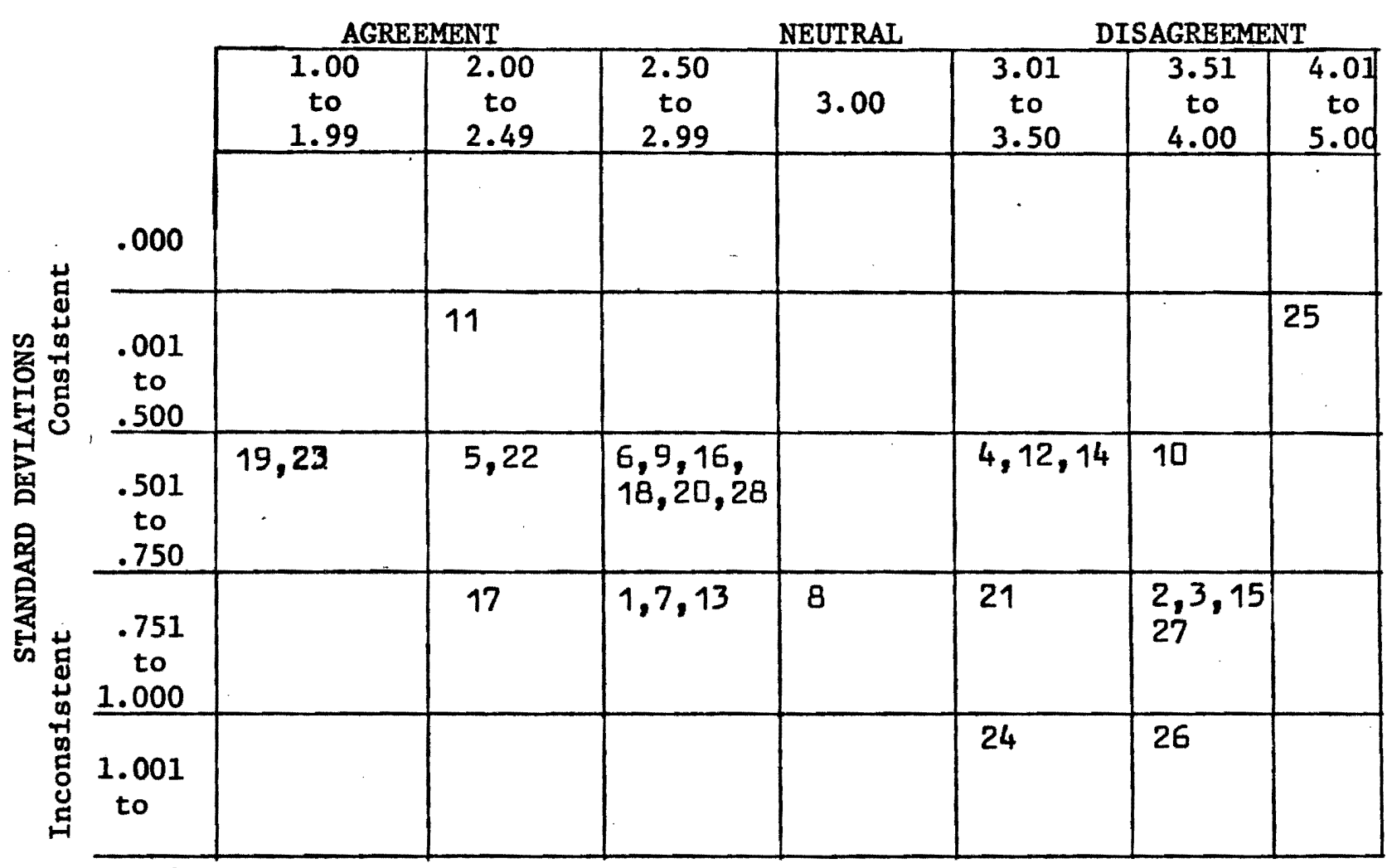


that runaways are a problem at the Louise Home. Those polled in East

Multnomah County fairly consistently strongly disagreed w1th question

25; that the Loulse Home is too far away to consider as a resource.

They less consistently disagreed with questions $2,3,10,15$, and 27;

or they disagreed that: 1) Communication was difficult with the

Louise Home; 2) the intake process is inconvenient; 3) girls have too

much freedom; 4) it is vague what type of girl to refer to the Louise Home; and 5) there are more convenient resources than the Loulse Home within the local community.

\section{Comments from Multnomah County - East}

"I have used the special treatment program for disturbed young boys presently operating at the Louise Home."

"I feel that these surveys are a poor measure of attitudes and opinions since what the questionner had in mind when he wrote the question and what the caseworker had in mind when he answers it must be considered. I would hope that Loulse Home would take into account the feedback it gets from caseworkers directly rather than making many changes based on results of this survey."

"Even though I have had no girls to refer to Loulse Home, It would be helpful to have a short written pamphlet of the treatment plan, etc."

"Don't know very much about it, therefore answers are not all-encompassing."

"Some of the chotce of answers does not relate to the question. I believe in treatment facilities, but caseload did not present me with a situation to learn more of the Louise Home program and facilities."

"I felt somewhat uncomfortable in completing this questionnaire as I have had little contact with the Loulse Home. However, in learning about the program through the 'grapevine' I would in general say that Louise Home is doing an effective job in meeting its specific goals and objectives." 
Multromah County - Southeast (see Table XIX, page 62).

In the Southeast Multnomah County: C.S.D., 70\% of the possible referrals were actually referred. Howeyer; Loufse Home recelyed only approximately $15 \%$ of those who were actually referred and accepted $33 \%$ of them. Villa: St. Rose was the additional agency mentioned most often by those polled; it was listed by $75 \%$ of the respondents.

In examining the attitudinal data, we find total strong agreement on question 17 , and fairly consistent strong agreement on questions 11,19 , and 23 . They a11 "strongly agreed" that runaways are a problem at the Louise Home; and less consistently "strongly agreed" that: 1) visits by friends and relatives are a part of a glrl's treatment program; 2) pre-placement visits are valuable; and 3) the school program is good. The respondents all agreed with questions $1,5,6,8,18$ and $22 ;$ and less consistently agreed with questions $9,10,16$ and 28 . They all agreed that: 1) the organizational structure facilitates Its operation; 2). caseworkers do an adequate job; 3) child care workers are competent; 42 the treatment philosophy is clear; 5) Louise Home provides a sound nutritional diet; and 6) the medical needs are met sufficiently at the Louise Home. They less consistently agreed that: 1) girls have too much freedom at the Louise Home; 2) the staff are in control; 3) the recreational program is an asset; and 4) there are more girls to refer during the school year. The respondents fairly consistently "strongly disagreed" with questions 15 and 25; they "strongly disagreed" that: 12 it was yague what type of girl to refer to the Louise Home; and 22 the Louise Home is too far away to constder a resource. The respondents all disagreed with question 4 ; fatrly consistently disagreed with question 2 ; and 
TABLE XIX : RESULTS

FROM MULTNOMAH (S.EAST)COUNTY

PART I: REFERRAL INFORMATION

\begin{tabular}{|l|c|c} 
& Number & $\begin{array}{l}\text { \% of } \\
\text { Total }\end{array}$ \\
\cline { 1 - 2 } $\begin{array}{l}\text { Total Possible } \\
\text { Referrals }\end{array}$ & 20 & 100 \\
\hline $\begin{array}{l}\text { Number Actually } \\
\text { Referred }\end{array}$ & 14 & 70 \\
\hline $\begin{array}{l}\text { Number Referred } \\
\text { to Louise Home }\end{array}$ & 3 & 15 \\
\hline $\begin{array}{l}\text { Number Accepted } \\
\text { at Louise Home }\end{array}$ & 1 & 5 \\
\hline
\end{tabular}

Length of Stay in Position to Refer Girls
$\underline{N}=4$

\begin{tabular}{l|c|l} 
& $\begin{array}{l}\text { Number } \\
\text { Listed }\end{array}$ & $\begin{array}{l}\% \text { of } \\
\text { Total }\end{array}$ \\
\cline { 2 - 3 } Villa St. Rose & 3 & 75 \\
\hline Farm Home & 1 & 25 \\
\hline Christy & 1 & 25 \\
\hline Youth Adventures & 1 & 25 \\
\hline Hillcrest & 1 & 25 \\
\hline White Shield & 1 & 25 \\
\hline Youth Care Center & & \\
\hline Chehalem House & & \\
\hline Boys \& Girls Alde & & \\
\hline Valadera & & \\
\hline Other & & \\
\hline No Response & & \\
\hline
\end{tabular}

PART II:ATTITUDINAL SURVEY

MEANS

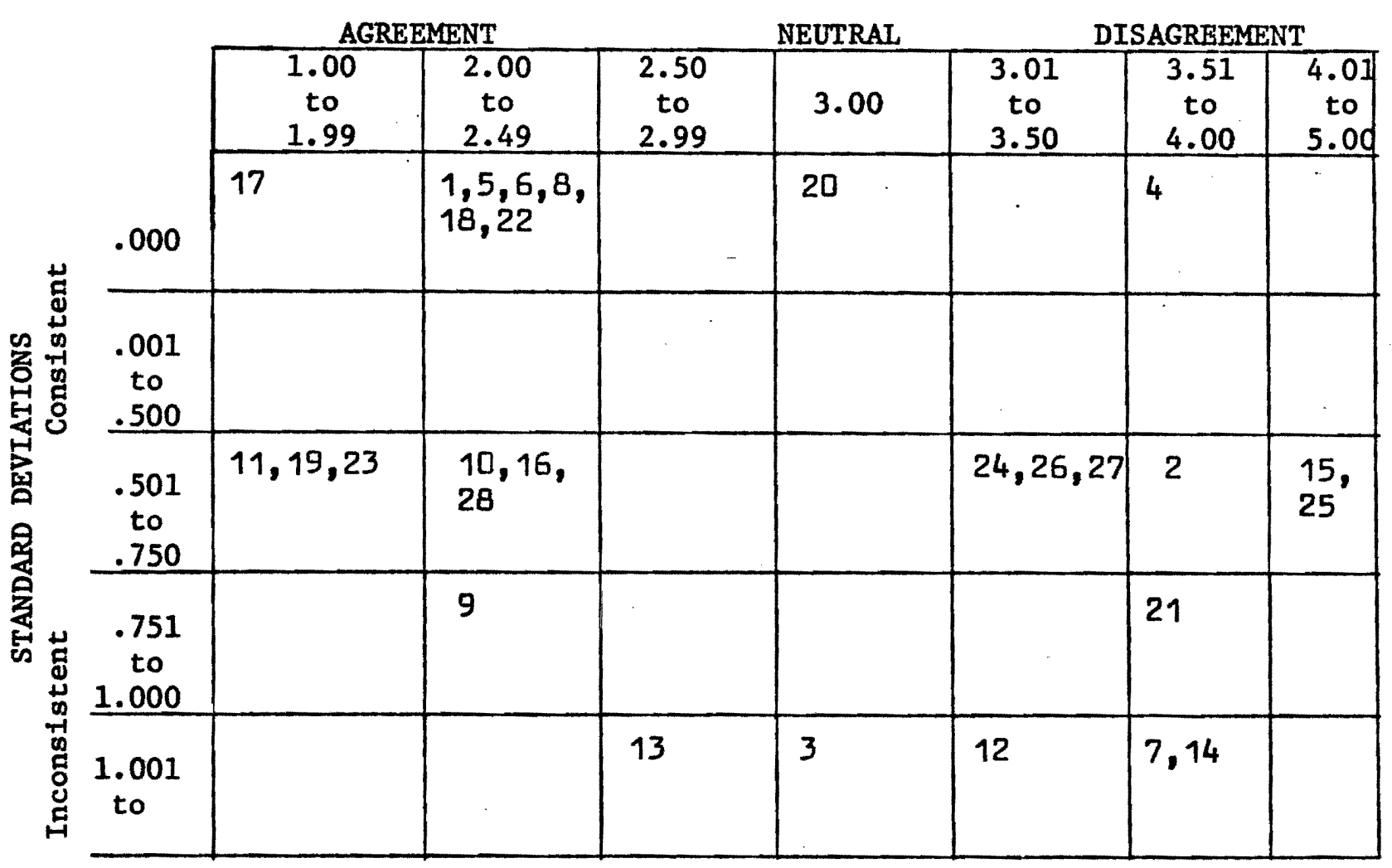


less consistently disagreed with question 21 . They all disagreed that: the Louise Home administration does not provide adequate leadership; fairly consistently disagreed that communication was difficult with the Louise Home; and less consistently disagreed that there was good follow-up after girls were released.

Multnomah County - West (see Table XX, page 64)

Referral data from West Multnomah County shows the following important facts: 1) They referred $56 \%$ of the total possible referrals; 2 ) that $40 \%$ of those actually referred were referred to the Louise Home; 3 ) Louise Home accepted $100 \%$ of those referred; and 4) that Christy and Villa St. Rose were mentioned by the respondents at a percentage of $50 \%$ and $33 \%$ respectively.

In the attitudinal data from this agency, we find fairly consistent agreement on questions 23 and 28 , and less consistent agreement on question 19; or they agreed that: 1) the school program was good; 2) there are more girls to refer during the school year; and less consistently agreed that pre-placement visits were valuable. The respondents fairly consistently "strongly disagreed" with question 26; or "strongly disagreed" with the statement that there were adequate resources for teenage girls within their own community. The six workers also fairly consistently disagreed with questions 10,25 , and 27 ; or disagreed that 1 ) girls haye too much freedom at the Louise Home; 2) the Loulse Home is too far away to consider as a resource; and 32 there are more convenient resources for teenage girls within their community. 
TABLE $X X$ : RESULTS

FROM MLLTNOMAH (WEST) COUNTY

PART I: REFERRAL INFORMATION

$\underline{N}=\underline{6}$

\begin{tabular}{|l|c|c} 
& Number & $\begin{array}{l}\% \text { of } \\
\text { Total }\end{array}$ \\
\hline $\begin{array}{l}\text { Total Possible } \\
\text { Referrals }\end{array}$ & 27 & 100 \\
\hline $\begin{array}{l}\text { Number Actually } \\
\text { Referred }\end{array}$ & 15 & 56 \\
\hline $\begin{array}{l}\text { Number Referred } \\
\text { to Louise Home }\end{array}$ & 6 & 22 \\
\hline $\begin{array}{l}\text { Number Accepted } \\
\text { at Louise Home }\end{array}$ & 6 & 22 \\
\hline
\end{tabular}

\begin{tabular}{l|c|c}
\multirow{2}{*}{ Villa St. Rose } & Number & $\begin{array}{c}\% \text { of } \\
\text { Total }\end{array}$ \\
\cline { 2 - 3 } & 2 & 33 \\
\hline Farm Home & & \\
\hline Christy & 3 & 50 \\
\hline Youth Adventures & & \\
\hline Hillcrest & 1 & 17 \\
\hline White Shield & & \\
\hline Youth Care Center & & \\
\hline Boys \& Girls Aide & & \\
\hline Valadera & & \\
\hline Other & & \\
\hline No Response & 2 & 33 \\
\hline
\end{tabular}

Length of Stay Average/Per.

in Position to 41 Months

PART II: ATTTTUDINAL SURVEY

MEANS

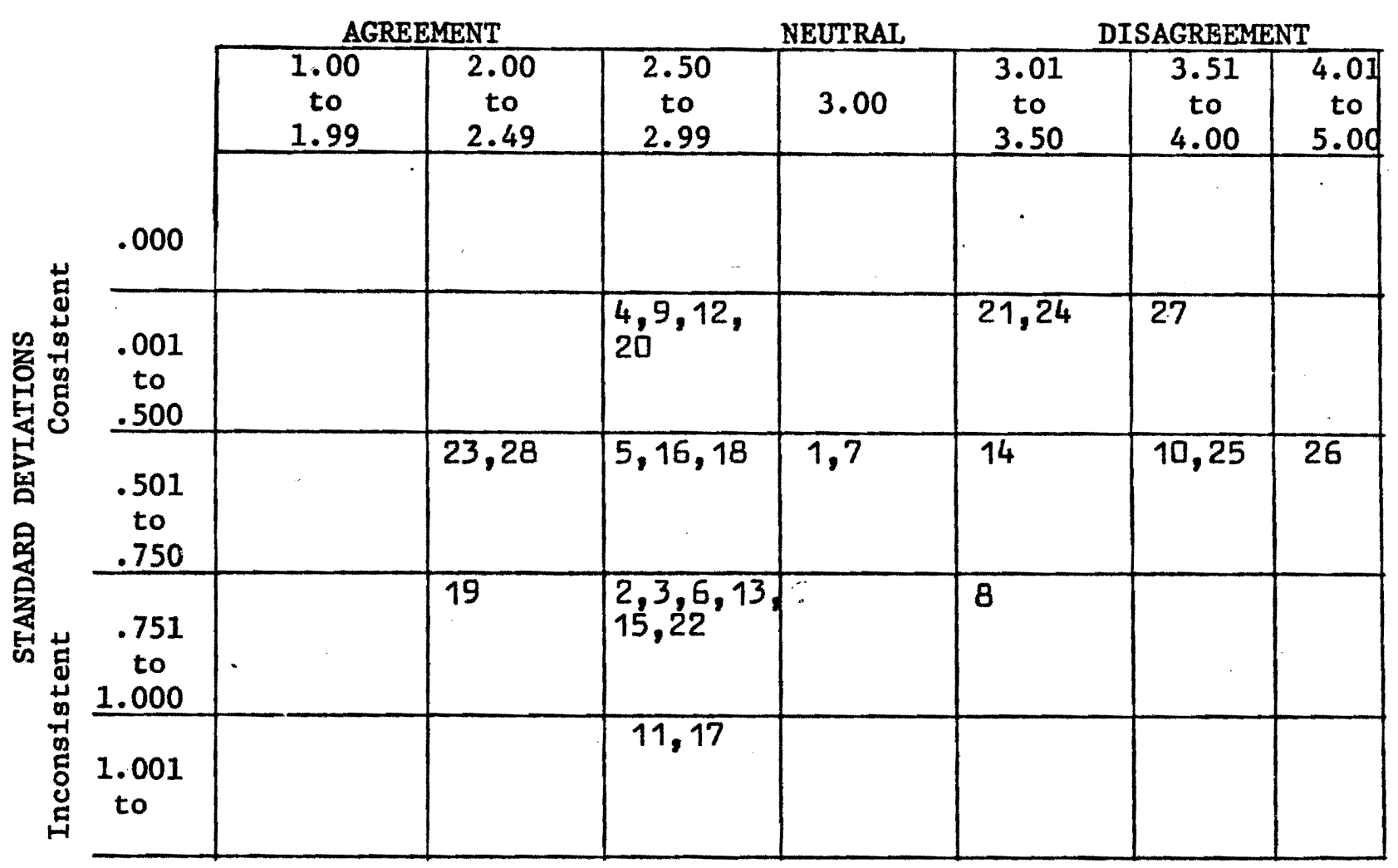


Comments from Multnomah County - West

"I strongly agree with Louise Home's basic policy

of taking back runaways. I feel there could be more time spent counseling the family as a whole."

"From my direct observation in having a girl at Louise Home for eighteen months (ending Jan. 1973) the home was showing a number of marked improvements in a number of areas including quality of staffing and in program content."

Polk and Yamhill Counties (see Table XXI, page 66)

The referral data from Polk-Yamhill C.S.D. shows the following:

1) they actually referred $76 \%$ of their total possible referrals;

2) of the actual referrals, Louise Home received approximately $33 \%$; and 3) $100 \%$ of those filling out the questionnatre listed Villa St. Rose and Chehalem House as other centers to which they referred girls.

In the attitudinal survey the respondents fairly consistently "strongly agreed" with questions 23 and 28; or that the school program was good; and there were more girls to refer during the school year. There was complete agreement among the respondents to question 5; that caseworkers do an adequate job at the Louise Home. There was fairly consistent agreement on questions 6 and 16, and less frequent agreement on 9,11 , and 13; or they agreed that: 1) Louise Home child care workers are competent; 22 the staff are in control; and less consistently agreed that: 1) the recreational program is an asset; 2) visits are usually a part of a girl's treatment program; and 3) the Louise Home provides an effective residential treatment program. There was fairly consistent strong disagreement with questions 12,26 and 27; or strong disagreement that: 1) home visit arrangements are not we11 planned; 2) there are adequate local resources for teenage girls; and 3) there are more convenient local resources for teenage girls. All 
TABLE XXI : RESULTS

FROM POLK/YAMHILL_COUNTY

PART I: REFERRAL INFORMATION

\begin{tabular}{|l|c|c} 
& Number & $\begin{array}{c}\text { \% of } \\
\text { Total }\end{array}$ \\
\cline { 1 - 3 } $\begin{array}{l}\text { Total Possible } \\
\text { Referrals }\end{array}$ & 29 & 100 \\
\hline $\begin{array}{l}\text { Number Actually } \\
\text { Referred }\end{array}$ & 22 & 76 \\
\hline $\begin{array}{l}\text { Number Referred } \\
\text { to Louise Home }\end{array}$ & 8 & 28 \\
\hline $\begin{array}{l}\text { Number Accepted } \\
\text { at Louise Home }\end{array}$ & 6 & 21 \\
\hline
\end{tabular}

Length of Stay Average/Per. in Position to 38 Months

$$
\underline{N}=4
$$

\begin{tabular}{l|c|r}
\multirow{2}{*}{ Villa St. Rose } & $\begin{array}{l}\text { Number } \\
\text { Listed }\end{array}$ & $\begin{array}{l}\% \text { of } \\
\text { Total }\end{array}$ \\
\cline { 2 - 3 } & 4 & 100 \\
\hline Farm Home & 2 & 50 \\
\hline Christy & & \\
\hline Youth Adventures & 1 & 25 \\
\hline Hillcrest & 1 & 25 \\
\hline White Shield & 1 & 25 \\
\hline Youth Gare Center & & \\
\hline Chehalem House & 4 & 100 \\
\hline Boys \& Girls Aide & & \\
\hline Valadera & & \\
\hline Other & 2 & 50 \\
\hline No Response & & \\
\hline
\end{tabular}

PART II:ATTITUDINAL SURVEY

MEANS

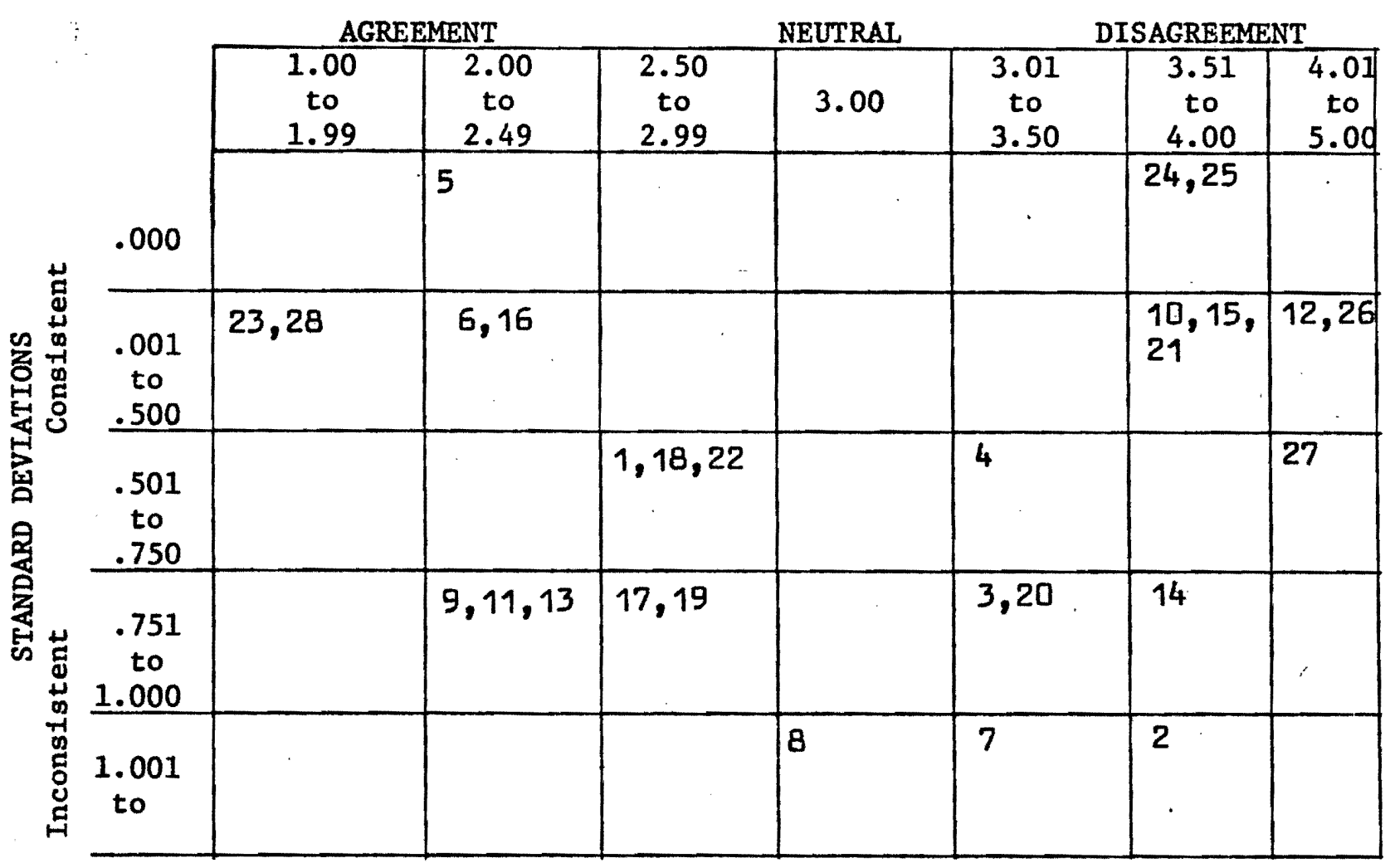


the workers disagreed with questions 24 and 25 ; or disagreed that:

1) the Loufse Home places too great an emphasis on religion; and 2) the Louise Home is too far away to consider as a resource. They fairly consistently disagreed with questions $10, .15$ and 21 ; or disagreed that: 1) girls at the Louise Home have too much freedom; 22. It is yague what type of girl to refer; and 3) there is good follow-up after a gir1 is released. There was less consistent agreement on question 14; or they generally disagreed that the recreational program is not a valuable part of treatment at the Louise Home.

\section{Comments from Polk and Yamh111 Counties}

"Communication and joint planning with caseworkers at Loulse Home has improved. Object to one hour pre-placement screenings. Would prefer to bring girl up for one week visit and remove if she doesn't fit into the program."

"I" am not that familiar with specifics of treatment or actual functioning, but know that they have done an excellent job with an extremely disturbed girl I referred to them."

"Although I didn't refer any girls this past year I have had one gir1 there since 1972, and have had a number there in past years."

Umatilla County: (see Table XXII, page 68)

The referral information from Umatilla County indicates that the Loulse : Home accepted only $30 \%$ of the number actually referred to itt The average length of stay in a position of referral was 15 months longer than the average for the total sample. In addition, $67 \%$ of those filling out the questionnaires did not indicate any other treatment center to which they referred girls.

Considering the attitudinal data, there was fairly consistent agreement with statements $5,6,22$ and 28 , or agreement that: 1 ) the caseworkers are competent; 2) the child care workers are adequate; 
TABLE XXII: RESULTS FROM UMATILLA COUNTY

PART I: REFERRAL INFORMATION

$\underline{N}=\underline{6}$

\begin{tabular}{l|l|l} 
& $\begin{array}{l}\text { Number } \\
\text { Listed }\end{array}$ & $\begin{array}{l}\% \text { of } \\
\text { Total }\end{array}$ \\
\cline { 2 - 3 } Villa St. Rose & & \\
\hline Farm Home & & \\
\hline Christy & 1 & 17 \\
\hline Youth Adventures & & \\
\hline Hillcrest & & \\
\hline White Shield & & \\
\hline Youth Care Center & & \\
\hline Chehalem House & 1 & 17 \\
\hline Boys \& Girls Aide & & \\
\hline Valadera & & \\
\hline Other & 1 & 17 \\
\hline No Response & 4 & 67 \\
\hline
\end{tabular}

\begin{tabular}{|l|c|c} 
& Number & $\begin{array}{l}\text { \% of } \\
\text { Total }\end{array}$ \\
\hline $\begin{array}{l}\text { Total Possible } \\
\text { Referrals }\end{array}$ & 20 & 100 \\
\hline $\begin{array}{l}\text { Number Actually } \\
\text { Referred }\end{array}$ & 10 & 50 \\
\hline $\begin{array}{l}\text { Number Referred } \\
\text { to Louise Home }\end{array}$ & 4 & 20 \\
\hline $\begin{array}{l}\text { Number Accepted } \\
\text { at Louise Home }\end{array}$ & 3 & 15 \\
\hline
\end{tabular}

Length of Stay in Position to Refer Girls
Average/Per. 50 Manths
PART II:ATTITUDINAL SURVEY

MEANS

\begin{tabular}{|c|c|c|c|c|c|c|c|c|}
\hline \multirow{3}{*}{\multicolumn{2}{|c|}{.000}} & \multicolumn{3}{|c|}{ AGREEMENT } & NEUTRAL & \multicolumn{3}{|c|}{ DISAGREEMENT } \\
\hline & & $\begin{array}{c}1.00 \\
\text { to } \\
1.99 \\
\end{array}$ & $\begin{array}{c}2.00 \\
\text { to } \\
2.49 \\
\end{array}$ & $\begin{array}{c}2.50 \\
\text { to } \\
2.99 \\
\end{array}$ & 3.00 & $\begin{array}{l}3.01 \\
\text { to } \\
3.50 \\
\end{array}$ & $\begin{array}{c}3.51 \\
\text { to } \\
4.00 \\
\end{array}$ & $\begin{array}{r}4.01 \\
\text { to } \\
5.00 \\
\end{array}$ \\
\hline & & & & & & & & \\
\hline 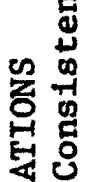 & $\begin{array}{l}.001 \\
\text { to } \\
.500 \\
\end{array}$ & 17 & & 18,20 & & & 25 & \\
\hline 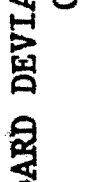 & $\begin{array}{l}.501 \\
\text { to } \\
.750 \\
\end{array}$ & & $5,6,22,28$ & 9 & & $4,7,12,24$ & 14,26 & \\
\hline 蛋 & $\begin{array}{r}.751 \\
\text { to } \\
1.000 \\
\end{array}$ & & 11,23 & $\begin{array}{l}1,3,13 \\
16,19\end{array}$ & & 2 & & \\
\hline 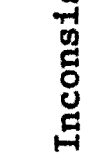 & $\begin{array}{c}1.001 \\
\text { to }\end{array}$ & & & 10 & 27 & $8,15,21$ & & \\
\hline
\end{tabular}


3) the medical needs of the girls are sufficiently met; and 4) there are more girls to refer during the school year than in the summer. There was less consistent agreement that the school program was good. In addition, there was consistent strong agreement that runaways are a problem at the Louise Home: And, lastly, there was consistent disagreement with statements 25,14 and 26 ; or disagreement that:

1) the Louise Home is too far away to consider as a resource;

2) there are more convenient resources 1ocally; and 3) the recreational program is not a valuable part of treatment.

\section{Comments from Umatilla County}

"Some questions are impossible to answer because we have never heard about what medical staff they have, wat they eat, what recreation there is. I don't particularly like the type of answers or choices Indicated for certain questions."

"I have referred girls several years ago to their progran and I have felt that they did every effort to help our referrals:"

Union County (see Table XXIII, page 702

The referral information from Union County shows that the Louise Home accepted half of the number actually referred. This information is based on only one person's questionnaire, but importantly, this person has been in a position of referral 14 months longer than the average person in the study.

Considering the attitudinal data, there was strong agreement with statement 23, that the school program is good. There was strong disagreement with statements 26 and 27 , that there are adequate and more convenient resources for adolescent girls 1oca11y. There was also strong disagreement that the release of girls from the Louise Home is well planned (statement 20). In addition, there 
TABLE XXIII : RESULTS FROM UNION COUNTY

PART I: REFERRAL INFORMATION

$\underline{N}=\underline{1}$

\begin{tabular}{|l|c|c} 
& Number & $\begin{array}{l}\% \text { of } \\
\text { Total }\end{array}$ \\
\hline $\begin{array}{l}\text { Total Possible } \\
\text { Referrals }\end{array}$ & 2 & 100 \\
\hline $\begin{array}{l}\text { Number Actual1y } \\
\text { Referred }\end{array}$ & 2 & 100 \\
\hline $\begin{array}{l}\text { Number Referred } \\
\text { to Louise Home }\end{array}$ & 1 & 50 \\
\hline $\begin{array}{l}\text { Number Accepted } \\
\text { at Louise Home }\end{array}$ & 1 & 50 \\
\hline
\end{tabular}

\begin{tabular}{l|c|c} 
& $\begin{array}{c}\text { Number } \\
\text { Listed }\end{array}$ & $\begin{array}{c}\% \text { of } \\
\text { Total }\end{array}$ \\
\cline { 2 - 3 } Villa St. Rose & 1 & 100 \\
\hline Farm Home & & \\
\hline Christy & & \\
\hline Youth Adventures & & \\
\hline Hillcrest & & \\
\hline White Shield & & \\
\hline Youth Care Center & & \\
\hline Chehalem House & & \\
\hline Boys \& Girls Aide & & \\
\hline Valadera & 1 & 100 \\
\hline Other & & \\
\hline No Response & & \\
\hline
\end{tabular}

Length of Stay in Position to Refer Girls

Average/Per.

48 Months

\section{PART II: ATTITUDINAI SURVEY}

\section{MEANS}

\begin{tabular}{|c|c|c|c|c|c|c|c|}
\hline & & EMENT & & NEUTRAL & & SAGREEI & ENT \\
\hline & $\begin{array}{c}1.00 \\
\text { to } \\
1.99 \\
\end{array}$ & \begin{tabular}{|c|}
2.00 \\
to \\
2.49 \\
\end{tabular} & $\begin{array}{r}2.50 \\
\text { to } \\
2.99 \\
\end{array}$ & 3.00 & $\begin{array}{c}3.01 \\
\text { to } \\
3.50 \\
\end{array}$ & $\begin{array}{c}3.51 \\
\text { to } \\
4.00 \\
\end{array}$ & $\begin{array}{c}4.01 \\
\text { to } \\
5.00 \\
\end{array}$ \\
\hline .000 & 23 & $\begin{array}{l}2,3,5,6, \\
12,13,15 \\
17,19,22 \\
28\end{array}$ & & $\begin{array}{l}3,8,9,11 \\
14,16,18 \\
24\end{array}$ & 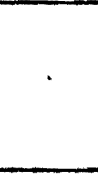 & $\begin{array}{l}1,4,10 \\
21,25\end{array}$ & $\begin{array}{l}20,26 \\
27\end{array}$ \\
\hline 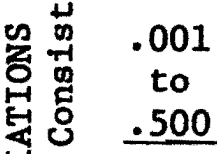 & & & & & & & \\
\hline $\begin{array}{ll}.501 \\
\text { to } \\
.750 \\
\end{array}$ & & & & & & & \\
\hline 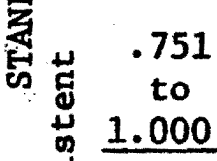 & & & & & & & \\
\hline $\begin{array}{cc}\text { 巳 } & 1.001 \\
\text { 巳 } & \text { to }\end{array}$ & & & & & & & \\
\hline
\end{tabular}


was agreement with statements $2,3,5,6,12,13,15,17,19,22$

and 28; or agreement that: 1) communication is difficult with the Louise Home; 2) the Intake process is inconyenient; 3) the caseworkers do an adequate $j o b ; 42$ the child care workers are competent;

5) home yisits aren't well planned; 6) the Louise Home is an effective residential treatment center; 7) it is vague what type of girl to refer; 8) runaways are a problem; 9) pre-placement visits are valuable; 10) medical needs of the girls are met sufficiently; 11) there are more girls in the school year to refer, than during the summer. On the other hand, there was disagreement with statements $1,4,10,21$ and 25 , or disagreement that: 1) the organizational structure of the Louise Home facilitates its operation; 2) the administration doesn' $t$ :provide effective leadership; 3) the girls have too much freedom; 4) there is good follow-up after release; and 5) the Louise Home is too far away to consider as a resource.

\section{Comments from Union County}

"Ourexperience has been that the success of a placement at Louise Home is so dependent on the individual caseworker who is assigned the case. of the two cases I've been involyed with at Louise Home, I felt they have done an excellent job with the one. The caseworker communicates readily with the county and planning is a cooperative effort. The other case is a different story. One week we receive a report that things are going we1l. The next week we receive a telephone call demanding we pick up the girl immediately as she is no 1onger appropriate for their program. In all falrness; however, the girl was a pill, and there were personality clashes involyed." 
Wa1lowa County: (see Table XXIV, page 73)

The referral information from Wallowa County is from one individual. This person referred all of his or her actual referrals to the Louise Home ( 2 girls); none of which were accepted. Sixteen out of the twenty attitudinal responses were neutral. This may be related to the individual's relatively short length of time in a position to refer girls, and lack of any on-going contact with the Louise Home. There was agreement with statements $1,2,3$, 4, 17 and 19. Hence this worker felt that communication with the Louise Home is difficult, the intake process is inconyenient, and runaways are a problem. The worker agreed strongly with statement 15, that it is vague what type of girl should be referred to the Louise : Home.

\section{Comments from Wallowa County:}

"The completion of this questionnaire is extremely vague because I have never had a girl enter or complete the program at Louise Home." In the referral material sent to me by Louise Home, the type of girl who should be referred to this facility is clearly stated. However my two contacts with this facility left me with the feeling that my referrals were inappropriate because they would be too hard to handle. I have never sent a written referral to Louise Home because my initial phone contacts were negative, and I received verbal Indication that my referrals were unacceptable. My office is in a very small county where resources are extremely 1imited."

Washington County (see Table XXV, page 74)

The data from Washington County was proyided by one person. All of the girls actually referred to the Louise Home were accepted by the Louise Home. No other treatment center was listed as a referral source. 
TABLE XXIV: RESULTS

FROM WALLOWA COUNTY

PART I: REFERRAL INFORMATION

\begin{tabular}{|l|c|c} 
& Number & $\begin{array}{l}\% \text { of } \\
\text { Total }\end{array}$ \\
\hline $\begin{array}{l}\text { Total Possible } \\
\text { Referrals }\end{array}$ & 2 & 100 \\
\hline $\begin{array}{l}\text { Number Actually } \\
\text { Referred }\end{array}$ & 2 & 100 \\
\hline $\begin{array}{l}\text { Number Referred } \\
\text { to Louise Home }\end{array}$ & 2 & 100 \\
\hline $\begin{array}{l}\text { Number Accepted } \\
\text { at Louise Home }\end{array}$ & 0 & 0 \\
\hline
\end{tabular}

Length of Stay in Position to Refer Girls
Average/Per.

20 Manths
$\underline{N}=$

\begin{tabular}{l|c|c} 
& Number & $\begin{array}{l}\% \text { of } \\
\text { Total }\end{array}$ \\
\cline { 2 - 3 } Villa St. Rose & 1 & 100 \\
\hline Farm Home & 1 & 100 \\
\hline Christy & & \\
\hline Youth Adventures & & \\
\hline Hillcrest & & \\
\hline White Shie1d & & \\
\hline Youth Care Center & & \\
\hline Chehalem House & & \\
\hline Boys \& Girls Aide & & \\
\hline Valadera & 1 & 100 \\
\hline Other & & \\
\hline No Response & & \\
\hline
\end{tabular}

\section{PART II: ATTITUDINAL SURVEY}

MEANS

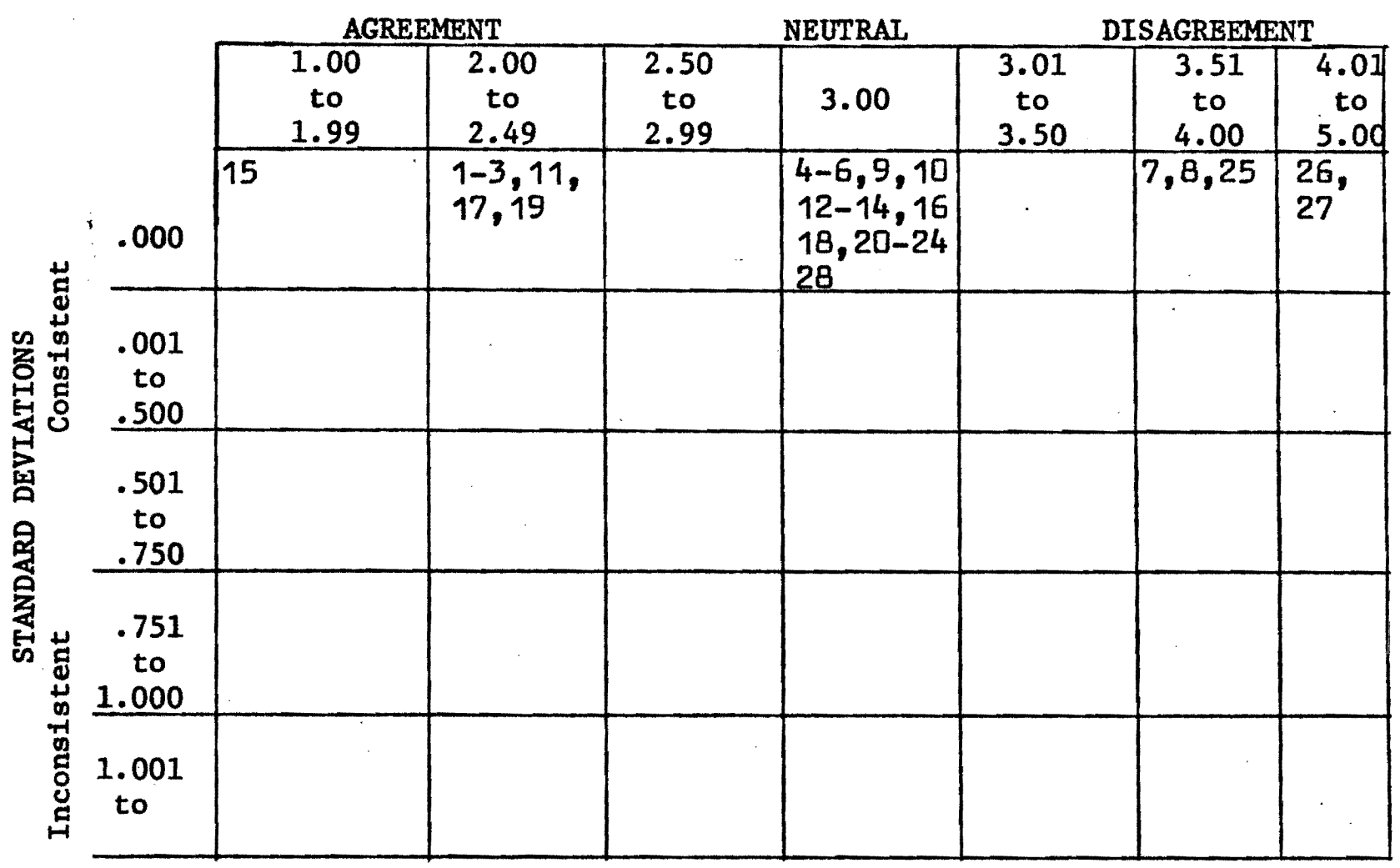


TABLE XXV : RESULTS

FROM WASHINGTUN COUNTY

PART I: REFERRAL INFORMATION

\begin{tabular}{|l|c|c|} 
& Number & $\begin{array}{l}\text { \% of } \\
\text { Total }\end{array}$ \\
\hline $\begin{array}{l}\text { Total Possible } \\
\text { Referrals }\end{array}$ & 4 & 100 \\
\hline $\begin{array}{l}\text { Number Actually } \\
\text { Referred }\end{array}$ & 3 & 75 \\
\hline $\begin{array}{l}\text { Number Referred } \\
\text { to Louise Home }\end{array}$ & 4 & 100 \\
\hline $\begin{array}{l}\text { Number Accepted } \\
\text { at Louise Home }\end{array}$ & 3 & 75 \\
\hline
\end{tabular}

Length of Stay Average/Per. In Position to NA Refer Girls

$$
\underline{N}=1
$$

\begin{tabular}{l|l|l} 
& $\begin{array}{l}\text { Number } \\
\text { Listed }\end{array}$ & $\begin{array}{l}\% \text { of } \\
\text { Total }\end{array}$ \\
\cline { 2 - 3 } Villa St. Rose & & \\
\hline Farm Home & & \\
\hline Christy & & \\
\hline Youth Adventures & & \\
\hline Hillcrest & & \\
\hline White Shield & & \\
\hline Youth Care Center & & \\
\hline Chehalem House & & \\
\hline Boys \& Girls Aide & & \\
\hline Valadera & & \\
\hline Other & & \\
\hline No Response & 1 & 100 \\
\hline
\end{tabular}

\section{PART II: ATTITUDINALSURVEY}

MEANS

\begin{tabular}{|c|c|c|c|c|c|c|c|}
\hline \multirow[b]{3}{*}{.000} & \multicolumn{3}{|c|}{ AGREEMENT } & \multicolumn{2}{|l|}{ NEUTRAI } & \multicolumn{2}{|c|}{ OISAGREEMENT } \\
\hline & $\begin{array}{c}1.00 \\
\text { to } \\
1.99 \\
\end{array}$ & $\begin{array}{c}2.00 \\
\text { to } \\
2.49\end{array}$ & $\begin{array}{c}2.50 \\
\text { to } \\
2.99\end{array}$ & 3.00 & $\begin{array}{c}3.01 \\
\text { to } \\
3.50\end{array}$ & $\begin{array}{c}3.51 \\
\text { to } \\
4.00\end{array}$ & $\begin{array}{c}.01 \\
\text { to } \\
5.00\end{array}$ \\
\hline & 17 & $\begin{array}{l}1,5-7,9 \\
11,16,19 \\
22,23\end{array}$ & & $\begin{array}{l}2,8,13, \\
18,20,28\end{array}$ & & $\begin{array}{l}3,4,10 \\
12,14 \\
15,21 \\
24-27\end{array}$ & . \\
\hline 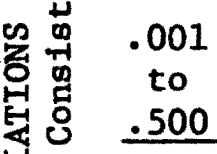 & & & - & & & & \\
\hline $\begin{array}{ll}.501 \\
\text { 置 } & \text { to } \\
& .750 \\
\end{array}$ & & & & & & & \\
\hline 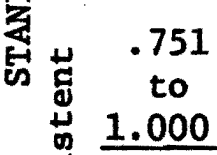 & . & & & & & & \\
\hline $\begin{array}{cc}\text { 号 } & 1.001 \\
\text { 号 } & \text { to }\end{array}$ & & & & & & & \\
\hline
\end{tabular}




\section{Washington County (continued)}

Considering the attitudinal data, the neutral response was used for six statements. : There was agreement with statements 1 , $5,6,7,9,11,16,22$ and 23, reflecting a posittve attitude towards administration, casework, child care, and the school program. There was disagreement with statements $3,4,10,12,14,15,21$, $24,25,26$ and 27 A11 of these statements were negatively constructed statements, except for 21,26 and 27 The referral person did then disagree that there is good follow-ip, and that there are adequate and more convenient resources within Washington County for adolescent girls.: In general though, this worker's opinions about the Louise Home program proved to be overall yery positive.

\section{Linn County (Unit I) (see Table XXVI, page 76)}

The referral information from this county shows that $16 \%$ of the county's actual referrals were referred to the Louise Home and that Louise Home accepted none. In addition, half of the referral persons listed Villa St. Rose as another treatment center to which they referred. There was total agreement with statement 17 that runaways are a problem, and with statement 28 , that there are more girls to refer to the Louise Home during the school year, than during the summer. Likewise, statements 25,26 and 27 receiyed unanimous disagreement. Thus, for this county, the Louise Home was not too far away to consider as a resource. Moreoyer, the workers felt there were not adequate resources within their own commintty for adolescent girls. Responses to all other statements were unanimously neutral, indicating a possible lack of knowledge about the program. 
TABLE XXVI : RESULTS

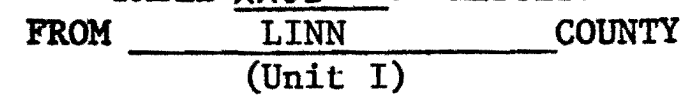

PART I: REFERRAL INFORMATION

$\underline{N}=\underline{4}$

\begin{tabular}{|l|c|c} 
& Number & $\begin{array}{l}\text { \% of } \\
\text { Total }\end{array}$ \\
\hline $\begin{array}{l}\text { Total Possible } \\
\text { Referrals }\end{array}$ & 14 & 100 \\
\hline $\begin{array}{l}\text { Number Actually } \\
\text { Referred }\end{array}$ & 8 & 57 \\
\hline $\begin{array}{l}\text { Number Referred } \\
\text { to Louise Home }\end{array}$ & 1 & 7 \\
\hline $\begin{array}{l}\text { Number Accepted } \\
\text { at Louise Home }\end{array}$ & 0 & 0 \\
\hline
\end{tabular}

\begin{tabular}{l|c|c} 
& Number & $\begin{array}{c}\% \text { of } \\
\text { Total }\end{array}$ \\
\cline { 2 - 3 } Villa St. Rose & 2 & 50 \\
\hline Tarm Home & & \\
\hline Christy & 1 & 25 \\
\hline Youth Adventures & & \\
\hline Hillcrest & & \\
\hline White Shield & & \\
\hline Youth Care Center & & \\
\hline Chehalem House & & \\
\hline Boys \& Girls Aide & & \\
\hline Valadera & & \\
\hline Other & 4 & 100 \\
\hline No Response & & \\
\hline
\end{tabular}

PART II: ATTITUDINAL SURVEY

MEANS

\begin{tabular}{|c|c|c|c|c|c|c|c|}
\hline & & IENT & & NEUTRAL & & SAGREE & \\
\hline & $\begin{array}{c}1.00 \\
\text { to } \\
1.99 \\
\end{array}$ & $\begin{array}{c}2.00 \\
\text { to } \\
2.49 \\
\end{array}$ & $\begin{array}{c}2.50 \\
\text { to } \\
2.99 \\
\end{array}$ & 3.00 & $\begin{array}{c}3.01 \\
\text { to } \\
3.50 \\
\end{array}$ & $\begin{array}{c}3.51 \\
\text { to } \\
4.00 \\
\end{array}$ & $\begin{array}{r}4.01 \\
\text { to } \\
5.00 \\
\end{array}$ \\
\hline .000 & & 17,28 & & $\begin{array}{l}1-16,18- \\
24\end{array}$ & & $25-27$ & \\
\hline 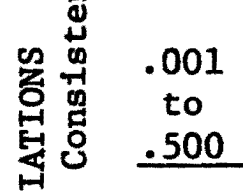 & & & & & & & \\
\hline $\begin{array}{c}.501 \\
\text { to } \\
.750 \\
\end{array}$ & & & & & & & \\
\hline $\begin{array}{cc} & 751 \\
\text { 岕苞 } & \text { to } \\
& 1.000 \\
\end{array}$ & & & & & & & \\
\hline 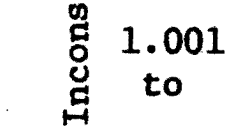 & & & & & & & \\
\hline
\end{tabular}


Comments from LInn County (UnIt I)

"Seems ridiculous to fill out this form when I haye never used the resource simply to meet an arbitrary criterla for numbers of forms completed!"

"I am not familiar enough with the Loufse Home or it's policy to participate in this research project."

"I do not have any direct knowledge of present Louise Home operation as I have had no girls in residence there for several years."

"I have had no contact with the home:"

Linn County (Unit II) (see Table XXVII, page 78)

The referral information for this county indicates that the sample referred $50 \%$ of their actual referrals to the Louise Home and had $50 \%$ of them accepted. In addition, the average length of time in a position of referral was nearly 20 months less than the total sample average of 34 months, which suggests that the workers tended to be new. Half of the sample listed Villa:St. Rose as an additional referral resource.

The majority of this county!s attitudinal responses were either neutral $(13,17,20,21,22,24,28)$, slightly in agreement $(1,5$, $6,9,11,1516,18,23)$, or slightly in disagreement $(4,7,10,12$, $14,25)$. There was consistent agreement with question 23 that preplacement visits"are valuable; and less consistent agreement with question 3, that the intake process is inconvenient. There was consistent disagreement with statements 2 and 8 , or disagreement that it is difficult to communicate with the Louise Home and that the Loulse Home treatment philosophy is clear. There was less consistent disagreement with statements 26 and 27 . Here the county disagreed that there are adequate and more convenient residentlal treatment resources 1ocal1y. 


FROM $\frac{\text { TABLE } \frac{X X V I I}{\text { LINN }}=\text { RESULTS }}{\text { (Unit II) }}$

PART I: REFERRAL INFORMATION

\begin{tabular}{|l|c|c} 
& Number & $\begin{array}{l}\text { \% of } \\
\text { Total }\end{array}$ \\
\hline $\begin{array}{l}\text { Total Possible } \\
\text { Referrals }\end{array}$ & 8 & 100 \\
\hline $\begin{array}{l}\text { Number Actually } \\
\text { Referred }\end{array}$ & 4 & 50 \\
\hline $\begin{array}{l}\text { Number Referred } \\
\text { to Louise Home }\end{array}$ & 2 & 25 \\
\hline $\begin{array}{l}\text { Number Accepted } \\
\text { at Louise Home }\end{array}$ & 1 & 13 \\
\hline
\end{tabular}

Length of Stay in Position to Refer Girls

Average/Per. 18 Months
$\underline{N}=\underline{G}$

\begin{tabular}{l|c|c} 
& $\begin{array}{l}\text { Number } \\
\text { Listed }\end{array}$ & $\begin{array}{l}\% \text { of } \\
\text { Total }\end{array}$ \\
\cline { 2 - 3 } Villa St. Rose & 2 & 50 \\
\hline Farm Home & & \\
\hline Christy & & \\
\hline Youth Adventures & & \\
\hline Hillcrest & & \\
\hline White Shie1d & & \\
\hline Youth Care Center & & \\
\hline Chehalem House & & \\
\hline Boys \& Girls Aide & & \\
\hline Valadera & & \\
\hline Other & & \\
\hline No Response & 2 & 50 \\
\hline
\end{tabular}

PART II: ATTITUDINAL SURVEY

MEANS

\begin{tabular}{|c|c|c|c|c|c|c|c|}
\hline \multirow[b]{3}{*}{.000} & \multicolumn{2}{|c|}{ AGREEMENT } & & \multicolumn{2}{|l|}{ NEUTRAL } & \multicolumn{2}{|c|}{ ISAGREEMENT } \\
\hline & $\begin{array}{c}1.00 \\
\text { to } \\
1.99 \\
\end{array}$ & $\begin{array}{c}2.00 \\
\text { to } \\
2.49 \\
\end{array}$ & $\begin{array}{c}2.50 \\
\text { to } \\
2.99 \\
\end{array}$ & 3.00 & $\begin{array}{c}3.01 \\
\text { to } \\
3.50 \\
\end{array}$ & $\begin{array}{c}3.51 \\
\text { to } \\
4.00 \\
\end{array}$ & $\begin{array}{r}4.01 \\
\text { to } \\
5.00 \\
\end{array}$ \\
\hline & & & & $\begin{array}{l}13,17,20, \\
21,22,24 \\
28\end{array}$ & - & & \\
\hline 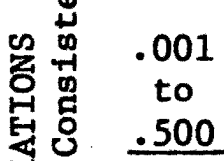 & & & & & & & \\
\hline $\begin{array}{cc}H & \\
& 501 \\
\text { 至 } & \text { to } \\
9 & .750 \\
\end{array}$ & & 19 & $\begin{array}{l}1,5,9,11, \\
15,16,18, \\
23\end{array}$ & & $\begin{array}{l}4,7,10, \\
12,14,25\end{array}$ & $2 B$ & \\
\hline 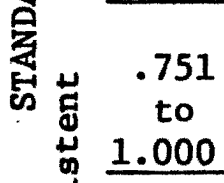 & & & & & & 26,27 & \\
\hline $\begin{array}{cc}\text { 异 } & 1.001 \\
\text { 吕 } & \text { to }\end{array}$ & & & & & & & \\
\hline
\end{tabular}


Comments from Ilinn County (Unit II)

"I have not had opportunity to observe Louise Home and form opinions on the previous questions.

Fincoln County: (see Table XXVIII, page 80)

This county referred nearly $50 \%$ of its actual referrals to the Louise Home; but only $50 \%$ of these were accepted. Villa St. Rose was 1 isted by $75 \%$ of the sample as an additional place of referral. In comparison the sample was also nearly two years "newer" in their positions of referral, than the average for all counties.

Overall, this county's responses to the attitudinal suryey tended to be diverse and extreme. There was total agreement with statements 6 and 16 ; and near total agreement with statements 1 and 11 . In other words, they agreed that: 1) the organizational structure facilitates Louise Home operation; 2) child care workers are competent; 3) the staff are in contro1; 4) visits by frlends and relatives are a part of a girl's treatment. There was also consistent strong agreement with statements 17,19 and 23 ; or strong agreement: 1) that runaways are a problem; 2) pre-placement yisits are yaluable; and 3) that the schoo1 program is good. There was less consistent agreement with statements 12, 15 and 20 , or agreement: 1) that home visits are not we11 planned; 2) that it is vague what type of girl to refer to the Loulse Home; 3) that the release of girls is well planned. In addition, there was consistent disagreement with statements 3,10 and 14 ; or disagreement 1) that the Intake process is inconvenlent;2) that the girls have too much freedom; and 3) that the recreational program is not a yaluable part of treatment. There was strong disagreement consistently with 
TABLE XXVIII: RESULTS

FROM IINCOIN_COUNTY

PART I: REFERRAL INFORMATION

$$
\underline{N}=\underline{4}
$$

\begin{tabular}{|l|c|c|} 
& Number & $\begin{array}{l}\text { \% of } \\
\text { Total }\end{array}$ \\
\hline $\begin{array}{l}\text { Total Possible } \\
\text { Referrals }\end{array}$ & 13 & 100 \\
\hline $\begin{array}{l}\text { Number Actually } \\
\text { Referred }\end{array}$ & 7 & 59 \\
\hline $\begin{array}{l}\text { Number Referred } \\
\text { to Loulse Home }\end{array}$ & 6 & 46 \\
\hline $\begin{array}{l}\text { Number Accepted } \\
\text { at Louise Home }\end{array}$ & 3 & 23 \\
\hline
\end{tabular}

\begin{tabular}{l|c|c} 
& $\begin{array}{l}\text { Number } \\
\text { Listed }\end{array}$ & $\begin{array}{l}\% \text { of } \\
\text { Total }\end{array}$ \\
\cline { 2 - 3 } Villa St. Rose & 3 & 75 \\
\hline Farm Home & & \\
\hline Christy & & \\
\hline Youth Adventures & & \\
\hline Hillcrest & & \\
\hline White Shield & & \\
\hline Youth Care Center & & \\
\hline Chehalem House & & \\
\hline Boys \& Girls Aide & & \\
\hline Valadera & & \\
\hline Other & 1 & 25 \\
\hline No Response & 1 & 25 \\
\hline
\end{tabular}

Length of Stay in Position to Refer Girls
Average/Per.

14.25 MONTHS

PART II ATTITUDINAL SURVEY

MEANS

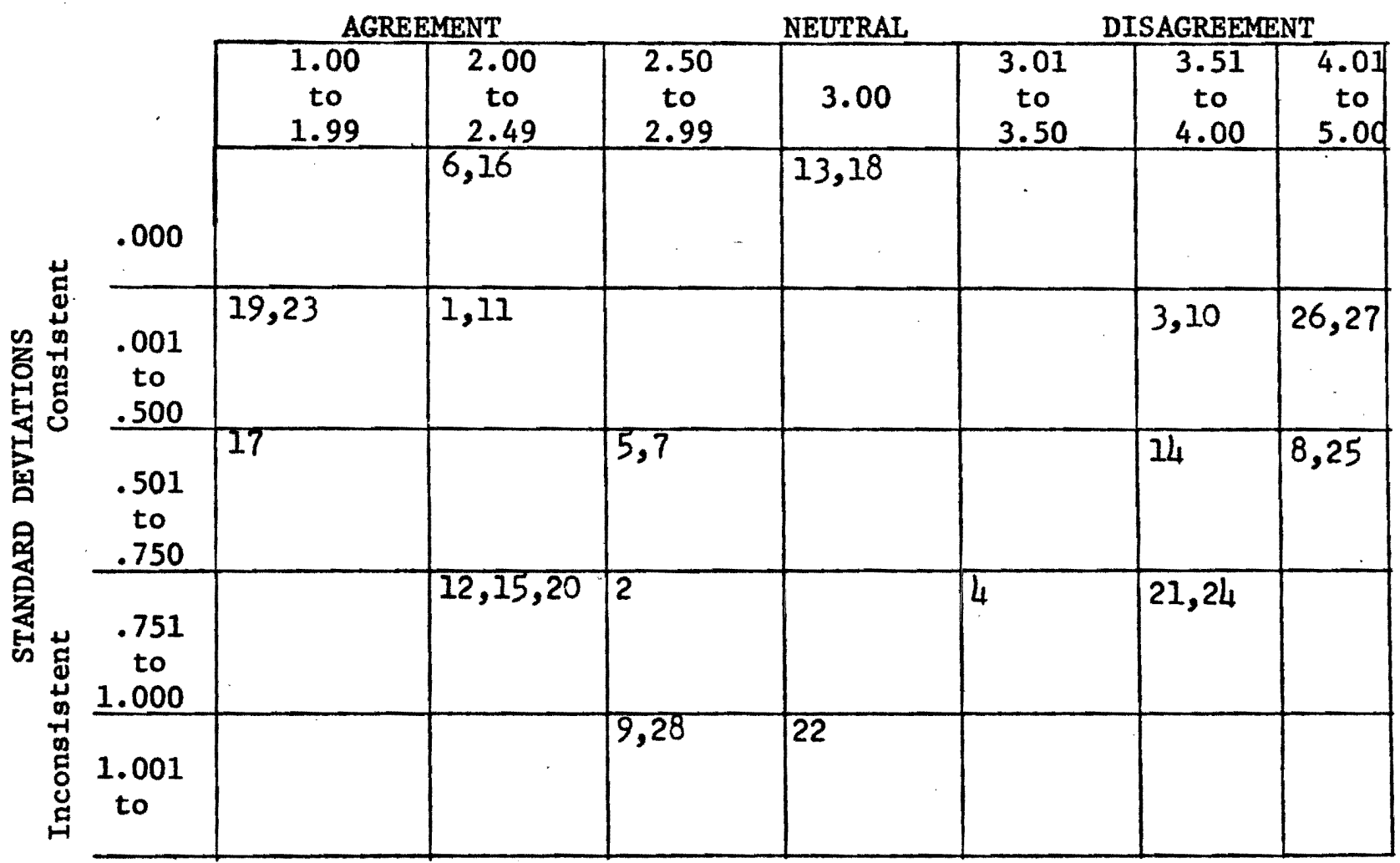


statements $26,27,8$ and 25 ; or strong disagreement: 1) that the Louise

Home treatment philosophy is clear to me; 2) that the Louise Home is too

far away; and 3) that there are more conyenient and adequate residential

treatment resources locally.

Comments from Lincoln County

"ChIld care centers require court wardship. I would consider Louise only to preyent making a child a ward. Treatment is about the same:"

"I: have very little first hand knowledge of the Louise Home, as I do not have a caseload of children and am not Involved in the referral process. However on several occasions it has come to my attention that there has been a lack of communication in planning. The Louise Home has sent girls home for visits without advising the local caseworker and has not advised the local agency of plans or included them in the plans. This has presented hardships for the girls as well as their workers: Louise Home has contacted our foster homes" without our knowledge such as making plans for a holiday visit." 



\section{EVALUATIONS}

Over-all, we are pleased with the study and 1ts results. We have, however, encountered certain problem areas and limitations. Our major problem involved the issue of sampling bias. Our original intention was to sample every caseworker in every county. We quickly realized that this would be Impossible for various reasons. For example, in Marion County the district director refused to administer the questionnaire to all his workers, and instead agreed to have only ten filled out by those who have had the most contact with the Louise Home. In other counties similar barriers to random sampling were present in different degrees. Therefore, having the district directors administer the questionnaire was good in that we were able to get a large return, but at the expense of having control over sampling bias. As a result our samples are by no means random. It is important to note then that our results and conclusions are only indications rather than firm statistical trends to make inferences. from.

other problems involved gaps in our analysis and questionnaire. For example, it would have helped to compute or correlate from our data how many individuals referred girls only to the Louise Home, only to other centers, or to both. We did not do this. It also would have helped in question six of PART I of the questionnaire to ask them how many girls they referred to each center they listed. Then we could have more accurately determined where each group tended to refer.

An additional area of concern was the fact that we failed to somehow differentiate the data from those counties who were grouped under one distrfct director. For example, in Harney and Malheur; Josephine and Jackson; Klamath and Lake; and Polk and Yamhill Counties 
we did not pre-arrange for the district directors to indicate in their returned questionnaires from which of the counties in their jurisdiction each one came. As a result we were not able to differentiate the attitudes of the individual counties involved.

Lastly, we have concerns about how we could have better dealt with the variable of distance, as it seems so essential to our analysis of a statewide treatment program. In PART II of the questionnaire we had one statement about distance "the Louise Home is too far away to consider as a resource." The response to this statement failed to get at the issue as we intended. We feel it tended to reflect instead a strong need for residential centers and a lack of them locally. It would have been valuable in our computer run to add the variable of physical distance and correlate it to all the attitudinal questions. An alternative would be to take key statements that seem to relate to distance, as home visits, follow-up, and pre-placement visits, and go through each county's responses to see if they varied according to the county's mileage from the Louise Home. This is an area then for further study. 


\section{CONCLUSIONS}

From our study we have put together three basic conclusions concerning: 1) the total sample response; 2) the Individual county responses; and 3) the correlations between referral information and the attitudinal responses.

Looking at the total sample, of the twenty-eight attitudinal responses nineteen were for the most part neutral with slight agreement or disagreement, four were consistent agreement, two were consistent disagreement, and one was consistent strong disagreement. Importantly though, the "agreements" In whatever degree they existed, tended to be with positive statements about the Louise Home program; and the "disagreements" w1th negative statements. In other words, looking at the total sample in and of Itself, it.seems that there is both a neutral and a positive attitude trend, with a few exceptions. These exceptions are significant to note in that they indicate areas of real and potentlal concern about the program. It is also significant to note those areas of the Louise Home program to which there are consistently posttive attitudes indicated to show the agency's felt strong points. The areas of concern then involved runaways, especially; the treatement philosophy; the follow-up after release. They felt strong points were pre-placement visits; the school program; and the handling of visits by friends and relatives. Looking lastly at the referral information for the total sample, it is our feeling that the Louise Home gets referred a large proportion of the actual referrals in the state (more than one-third); but that it only accepts a little over half of them.

Considering the results from each of the individual counties, the neutral and positive trend existing in the total sample is not as apparent. It is our finding that there is great variation from county to county in their attitudes and referral behaviors. This vartation is one not only of 
degree, but also of response. In other words each individual county is unique. Each county has different concerns, different areas about which they lack knowledge, as well as different areas in which they are satisfied with the Loulse Home program. It is difficult then to make any over-all conclusions concerning the individual counties, other than that they should be looked at and dealt with individually. Lastly with reference to the correlation between referral information and attitudinal responses, it is our finding that there does not seem to be an association between the number of girls referred to the Louise Home by an Individual CSD worker and his or her attitudes about the program as tested in our study. This lack of association also seems to hold true for the length of time the worker was in a position to refer girls to the Louise Home. In other words, It is apparent that contact with the Louise Home through the referral and placement process, as well as being in a position to refer girls to the Loulse Home, does not significantly effect worker's over-all attitudes about the program. We found this result to be perplexing, especially considering the extreme attitudes and comments at times. We considered the disagreement with statement 26 , and strong disagreement with statement 27 as a possible explanation for this seemingly incongruous result. More than any other two statements on the questionnaire these two had the most consistent and strong response. It is apparent then that an overriding attitude, almost above al1 others, in most counties was that "there was not adequate and more convenient resources locally for the type of girl that would be elfgible for the Louise Home program." This fact would seem to then partially explain why attitudes about the Louise Home do not yary with the number of referrals to it. The element of choice seems to haye 
been eliminated by the fact that what the Louise Home has to offer is a limited resource. If resources weren't so scarce for residential treatment of teenage girls, we feel that attitudes would tend to have more effect upon the number of girls referred by C.S.D. workers. In some counties we think there is a trend toward deyeloping more community resources. This leads us to believe that the Louise Home may not always be in its present position. In the future the Louise Home might be faced with decreasing referrals from county agencies. This may be due to the trend toward more localized treatment. 


\section{RECOMMENDATIONS}

We have four general recommendations. The first recommendation has to do with how we feel the data in the questionnaire may be utilized by the Louise Home personnel, and the others Involye suggestions of ways to follow up on this study.

1. There are four primary ways which we feel the Loulse Home may utilize the results of our study. They are as follows:

A. The social worker may use the data collected on each county in his/her daily contacts with the caseworkers from those counties. We feel this may allow the social worker to be more sensitive to the county caseworkers' areas of concern.

B. Data compiled on each county can be reviewed by Individuals making public relations visits in order to be more aware of and responsive to each county.

c. Data from the study could be used to evaluate the manner in which each county is being seryed by the Louise Home and why? It may be that for reasons of distance, size, etc. that counties cannot be served the same. For example, home and pre-placement visits may need to be planned more thoroughly where more distant counties are involved.

D. The data may be used to determine what areas of residential treatment need improvement with respect to the attitudes of each county.

2. We recommend further research in those counties whose responses indicate many negative attitudes. In our opinion these counties include Marion and Baker Counties. 
This could be as simple as sending an indiyidual to that county to gather more specific feedback about those areas of concern.

3. We suggest that the Louise Home prepare a brief eyaluation form which can be used upon termination with each girl. The form could be sent to the home county caseworker, asking them to eyaluate Louise Home services. Important areas to include would be: 1) pre-placement visits; 2) home visits, 3) termination; 42 follow-up care.

4. We suggest that those counties which had many "neutral" responses be giyen more information about the Louise Home and the type of program it provides. It is our contention that these counties know little about the seryices the Loutse Home has to offer. 
APPENDICES 


\section{INTRODUCTION}

THE FOLLOWING QUESTIONNAIRE HAS BEEN DESIGNED BY THREE GRADUATE STUDENTS FROM PORTLAND STATE UNIVERSTTY'S SCHOOL OF SOCIAL WORK. THE PURPOSE OF THE QUESTIONNAIRE IS: 1.) TO COLLECT PERTINENT REFERRAL DATA; AND 2.) TO SURVEY ATTITUDES OF CHILDREN'S SERVICES WORKERS TOWARDS THE LOUISE HOME PROGRAM. THE RESULTS OF THIS QUESTIONNAIRE WILL BE MADE AVAILABLE TO THE LOUISE HOME STAFF TO FACILITATE THE EVAIUATION OF THEIR TREATMENT PROGRAM.

IT IS REQUESTED THAT YOU ANSWER EACH QUESTION TO THE BEST OF YOUR ABILITY, AND THAT YOU RESPOND TO ALL OF THE QUESTIONS. THANK YOU FOR YOUR COOPERATION.

PART I: REFERRAI INFORMATION

1. Do you take part in the referral of girls between the ages of 12 and 18 for placement in residential treatment centers? (Circle One)

YES NO

2. Over the past year(1973) how many girls from the ages of 12 to 18 on your caseload could have benefitted from being placed in a residential treatment center? (Number of Cases)

3. How many of these girls did you refer to such residential centers in the past year (1973)? (Number of Cases)

4. How many girls did you refer to the Louise Home in the past year (1973)? (Number of Cases)

5. How many of the girls that you referred to the Louise Home in the past year (1973) were accepted? (Number of Cases)

6. To what other residential treatment centers did you refer girls in the 12 to 18 year old age group in the past year (1973)?. (Please List)

7. How long have you been in a position (present job placement) to be Involved in some way in the possible referral of girls to residential treatment centers? (Number of Months) 


\section{RART II; ATTITUDINAL SURVEY}

POR EACH OF THE FOLLOWING QUESTIONS THERE ARE FIVE POSSIBLE RESPONSES. PLEASE CIRCLE THE ONE RESPONSE FQR EACH QUESTION THAT BEST REPRESENTS YOUR QRINION.

\section{SAMPLE QUESTION:}

a. The Louise Home is a residential treatment center. strongly agree

agree neutral disagree

strongly disagree

1. The organizational structure at the Louise Home facilitates its operation. strongly agree agree neutral disagree strongly disagree

2. Trying to communicate with the Louise Home is difficult.

strongly agree agree neutral disagree strongly disagree

3. The intake process at the Louise Home is inconvenient.

strongly agree agree neutral disagree strongly disagree

4. The Louise Home administration does not provide effective leadership. strongly agree agree neutral disagree strongly disagree

5. Caseworkers at the Louise Home do an adequate job.

strongly agree agree neutral disagree strongly disagree

6. Louise Home child care workers are competent.

strong1y agree agree neutral disagree strongly disagree

7. The physical facilities at the Louise Home are below standard.

strongly agree agree neutral disagree strongly disagree

8. The Louise Home treatment philosophy is clear to me.

strongly agree agree neutral disagree strongly disagree

9. The recreation program is an asset to the Louise Home.

strongly agree agree neutral disagree strongly disagree

10. Girls at the Loulse Home haye too much freedom:

strongly agree agree neutral disagree strongly disagree

11. Visits by friends and relatives to the Louise Home are usually part of a girl's individual treatment program. 
12. Home visit arrangements are usually not well planned.

strongly agree agree neutral disagree strongly disagree

13, Loulse Home provides an effective residential treatment program.

strongly agree agree neutral disagree strongly disagree

14. The recreation program is not a valuable part of treatment at the Louise Home.

strongly agree agree neutral disagree strongly disagree

15. It is vague what type of girl should be referred to the Louise Home. strongly agree agree neutral disagree strongly disagree

16. The staff are in control at the Louise Home.

Jtrongly agree agree neutral disagree strongly disagree

17. Runaways are a problem at the Louise Home.

strongly agree agree neutral disagree strongly disagree

18. Louise Home provides a sound nutritional diet.

strongly agree agree neutral disagree strongly disagree

19. Pre-placement visits to the Louise Home are valuable.

strong1y agree agree neutral disagree strongly disagree

20. Release of girls from the Louise Home is well planned.

stronglyu agree agree neutral disagree strongly disagree

21. There is good follow-up by the Louise Home after girls are released. strongly agree agree neutral disagree strongly disagree

22. The medical needs of girls at the Louise Home are met sufficiently. strongly agree agree neutral disagree strongly disagree

23. The school program at the Louise Home is good.

strongly agree agree neutral disagree strongly disagree

24. The Louise Home places too great an emphasis on religion.

strongly agree agree neutral disagree $\quad$ strongly disagree 
25. The Louise Home is too far away to consider as a resource, strongly agree agree neutral disagree strongly disagree

26. There are adequate resources for teen-age girls who would be eligible for the Louise Home program within our own community.

27. There are more convenient resources for teenage girls who would be eligible for the Louise Home program within our own community.

strongly agree agree neutral disagree strongly disagree

28. There are more girls to refer to the Louise Home during the school year than during the summer.

strongly agree agree neutral disagree strongly disagree

COMMENTS : 


\section{Albertina Kerr Homes}

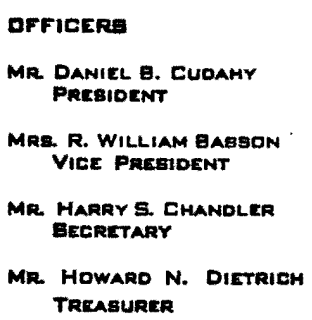

November

Dear

One of the continuing problems of providing services to troubled adolescent girls at the Louise Home, is giving a clear understanding of the services that we are able to provide to the community. In an effort to deal with this difficulty we have enlisted the aid of three graduate students from Portland State University, School of Social Work, in designing a study to gather attitudes from Children Service Workers regarding the Louise Home. The students involved in the project are: John Adsit, Wendy Heinz, and George Nagel. I feel that this study will be a great value to the Louise Home and your staff and would appreclate your assistance in this endeavor.

During the month of November one of the three above mentioned students will be phoning you to ask for some preliminary information which will include the following:

1. Who in your office can initiate a referral to the Loulse Home?

2. Must this referral be authorized? If so, by whom?

Once these students have gathered this preliminary information they will again be making contact with some of the Children's Services Division agencies in order to administer their questionnaire. I hope that with your cooperation they will be able to complete their research which we, in turn, hope to use to improve our service to you.

Sincerely yours,

LOUISE HOME

Guy Hancock

Director

$\mathrm{GH} / j \mathrm{j}$ 
Enclosed you will find the attitudinal questionnaires concerning the Loulse Home for Girls about which I contacted you. I appreclate very much your willingness to administer and return these questionnaires to us. The questionnaires themselves are selfexplanatory, and need only to be handed out and collected. I hope our work will assist the Louise Home to improve their service to your agency. Please have the questionnaires back to us as soon as possible, or by February 15th. I have enclosed a postage paid envelope for this purpose. After February 22nd, I will be unable to accept any additional questionnaires due to our deadline for the analysis of the data.

We very much want input from every county, and will be grateful If you return your questionnaires as quickly as possible. If you have any questions, please call 233-8252, and ask for John Adsit. Thank you.

Sincerely,

Wendy Bays

Portland State University

John Adsit

George Nage1

School of Social Work 
TOTAL SAMPLE TALLY SHEET FOR PART II OF ATTITUDINAL SURVEY

Q

1

2

2

3

4

5

6
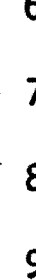

11

12

13

14

15

16

17

18

19

20

21

22

23

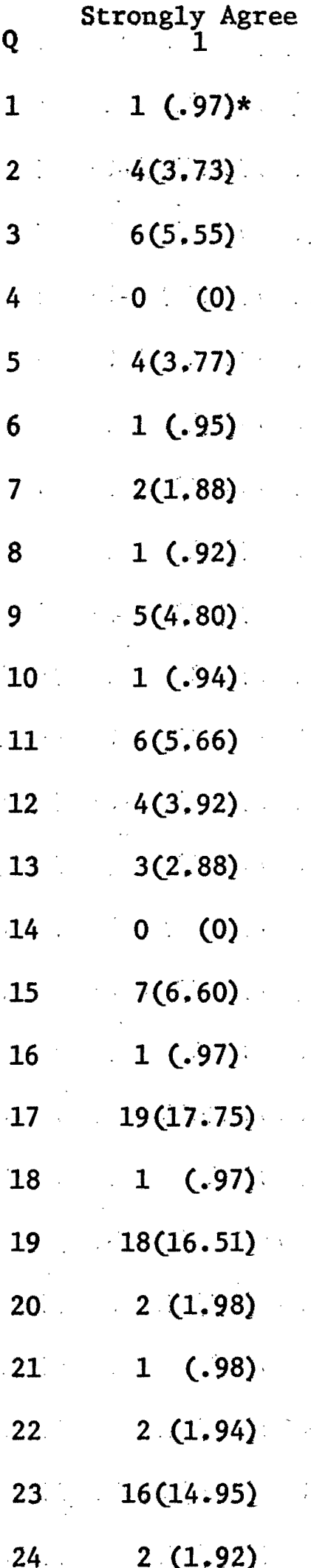

24

25

26

27.
Agree

$39(37.86)$

20 (18.69)

23 (21.29)

11 (10.38)

52 (49.05)

47. (44.76)

$15(14.50)$

21 (19.44)

$34(32.69)$

11 (10.37)

$62(58.49)$

13 (12.74)

$40(38.46)$

2. (1.94)

$31(29.24)$

45(43.68)

49(45.79)

$26(25.24)$

$69(63.30)$

22(21.78)

3 (2.94)

$44(42.71)$

$49(45.79)$

0 (0)

4. $(3,66)$

$6 .(5.45)$

11(10.28)

$44(47.30)$
Neutral

Disagree

Strong $\frac{1 y}{5}$ Disagree

$52(50.48) \quad 11(10.67)$

$30(28.03) \quad 45(42.05)$

$38(35.18) \quad 39(36.11)$

$63(59.43) \quad 32(20.19)$

$6 \cdot(5.66)$

4. $(3,80)$

$48(45.28)$

44(40.74)

3 (2.88)

$62(59.61)$

$36(33.96)$

$3(2.83)$

$24(23.52)$

$10(10.40)$

$42(40.77)$

42(39.62)

$5(4.85)$

$6 \cdot(5.60)$

$33(30.84)$

$76(73.78)$

0 . (0)

$16(14.68) \quad 5(4.59)$

$61(60.39) \quad 9(8.91)$

$60(58.80) \quad 28(27.45)$

6 (5.82)

1 (.93)

$66(63.46) \quad 31(29.80)$

$.17(15.59) \quad 73(66.97)$

$10(9.09) .59(53.63)$

$12(11: 21) \quad 53(49.53)$

$50(48.07) \quad 4(3.84)$
0. (0)

$8 \cdot(7.47)$

2 (1.85)

$0 \quad(00)$

1 (.94)

$0 \quad(0)$

2. (1.88)

14(12.96)

0. (0)

2 (1.88)

0 (0)

2 (1.96)

2 (1.92)

$4(3.88)$

2 (1.88)

1 (.97)

0 (0)

0 . (0)

1 (.92)

7 (6.93)

$10 \quad(9.80)$

$0 \quad(0)$

0 (0)

$5 \quad(4.80)$

14 (12.84)

$34(30.90)$

$29(27.10)$

1 (.96)

* $(\%)$ 